\title{
Evolutionary and ecological perspectives of Late Paleozoic ferns. Part III. Anachoropterid ferns (including Anachoropteris, Tubicaulis, the Sermayaceae, Kaplanopteridaceae and Psalixochlaenaceae)
}

\author{
Jean Galtier ${ }^{\text {a,* }}$, Tom L. Phillips ${ }^{b}$ \\ a UMR AMAP, CIRAD, TA-A51/PS2, Boulevard de la Lironde, 34398 Montpellier cedex 5, France \\ b Department of Plant Biology, University of Illinois, 265 Morrill Hall, 505 South Goodwin Ave., Urbana, IL 61801, USA
}

\section{A R T I C L E I N F O}

\section{Article history:}

Received 7 October 2013

Received in revised form 13 January 2014

Accepted 26 February 2014

Available online 25 March 2014

\section{Keywords:}

Filicalean fern

Evolution

Paleoecology

Permineralization

Carboniferous-Permian

\begin{abstract}
A B S T R A C T
The anachoropterid ferns, previously assigned to the family Anachoropteridaceae, are a group of anatomically preserved late Paleozoic filicalean ferns characterized by a C-shaped foliar xylem with abaxially recurved arms (inversicatenalean anatomy) and two main protoxylem strands. The variously curved to strongly inrolled foliar xylem certainly reflects different evolutionary trends within the morphogenus Anachoropteris. The occurrence of two groups of Tubicaulis is supported by differences in cauline and foliar anatomy and the presence vs. absence of precocious pinnae. Tubicaulis with solid protostele bears petioles which are not of the Anachoropteris type. Protostelic, rarely siphonostelic, cauline structures corresponding to several types of epiphyllous shoots are well documented on rachides of several Anachoropteris species and in the genus Kaplanopteris. These shoots, borne on dominant scrambling fronds, are a common means of vegetative propagation, similar to those known in the contemporaneous botryopterid ferns. This contrasts with the highly branched rhizomatous cauline system of Psalixochlaena (a whole plant reconstruction is provided) and the erect stems, of tree-ferns type, known in some Tubicaulis and the probably related Grammatopteris. A hemi-epiphytic habit characterized some Anachoropteris and Tubicaulis. This group of ferns therefore exhibited an important diversity of habits. Information on the distal regions of fronds, i.e. on pinnule morphology and fertile parts, is unfortunately missing in the majority of taxa. Where known, the pinnules are small and dissected, and sporangia, grouped in sori, have a lateral annulus. However, differences in soral and sporangial morphology support the recognition of the families Sermayaceae, Kaplanopteridaceae and Psalixochlaenaceae. The discovery of new fertile anachoropterid pinnae with adaxially borne branched soral receptacles will justify the distinction of a new family. Finally, there is no well supported anatomical evidence of fertile frond compressions belonging to anachoropterid ferns.
\end{abstract}

(c) 2014 Elsevier B.V. All rights reserved.

\section{Introduction}

In the first two parts of this review we recognized the Zygopteridales as an extinct group of true ferns known from the late Devonian to the early Permian (Phillips and Galtier, 2005) while Ankyropteris and other filicalean ferns of the family Tedeleaceae may have originated from the clepsydroid zygopterid clade (Phillips and Galtier, 2011). These two groups are distinct from all the other ferns by the possession of a phyllophore-type of petiole and, additionally, by a second kind of (small) leaf, known as vascularized aphlebiae, which cloak the stem. The present review concerns the filicalean anachoropterid ferns, based on anatomically preserved taxa, characterized by a petiolar

\footnotetext{
* Corresponding author.

E-mail address: jean.galtier@cirad.fr (J. Galtier).
}

xylem strand with abaxial curvature/concavity and typically two groups of protoxylem on the adaxial face. These ferns are sometimes referred to as "inversicatenaleans" due to the inverted orientation of their C-shaped foliar xylem strand in comparison to the commonly adaxially concave foliar strand of modern filicaleans.

The morphogenus Anachoropteris shows the maximum specific diversity with several evolutionary trends in curved to strongly inrolled foliar xylem (Galtier and Phillips, 1996). Our knowledge of Anachoropteris has long been restricted to their foliar structures. The first evidence of a cauline member was presented by Delevoryas and Morgan (1954) for Anachoropteris clavata (now transferred to the genus Kaplanopteris Tomescu et al., 2006). Many anachoropterid ferns exhibited epiphyllous shoots borne either laterally or adaxially, or resulting from dichotomy or trifurcation of the rachis (Phillips, 1974; Holmes, 1979). New data are provided in the present paper on these different types of shoots. These developmental strategies represent effective means of vegetative 
propagation which are well known in botryopterid ferns but absent in the contemporaneous zygopterid and ankyropterid ferns.

Tubicaulis was originally established for large erect stems with a solid protostele and C-shaped petiolar xylem which is different from the Anachoropteris-type. We document the occurrence of two groups of Tubicaulis differing in stelar and petiolar anatomy and presence vs absence of precocious pinnae. However, interconnections of some Tubicaulis showing a vitalized protostele with some Anachoropteris are now well established. Related genera included in this study are Psalixochlaena with a well documented dominant role of the dichotomous rhizome, the small protostelic to siphonostelic Apotropteris, and Grammatopteris, with erect stem and bar-shaped foliar xylem, rather similar to Tubicaulis. The broad diversity in size, branching and habit of anachoropterid ferns is discussed.

A few species are well known as whole plants, including laminate foliage and fertile parts with small annulate sporangia. They support the recognition of several filicalean families (Sermayaceae, Psalixochlaenaceae and Kaplanopteridaceae) but the radiation of the group remains to be documented in more detail. We provide a reconstruction of the whole plant Psalixochlaena based on the detailed studies by Holmes $(1977,1981 a)$. There are no well established compression assemblages of plants assignable to anachoropterid ferns.

In this review it is not our intent to taxonomically revise or establish new taxa but rather to complement the published observations and explore ecological and evolutionary implications.

\section{Materials and methods}

Fossil plants from the following collections and institutions have been studied and illustrated with these designated abbreviations in the explanations: MNHNP, Muséum National d'Histoire Naturelle, Paris; MHNA, Muséum d'Histoire Naturelle, Autun; NHM, Natural History Museum, London; NMP, National Museum, Prague; SMNHS, Swedish Museum Natural History, Stockholm; UI, University of Illinois, Champaign-Urbana; ULG, University de Liège; UM2, Université de Montpellier; and USTL, Université de Lille. In addition, materials from the Museum für Naturkunde, Berlin and Museum für Naturkunde, Chemnitz have been examined but not illustrated with the exception of pictures of Tubicaulis solenites (Plate XII, 1-3) and Grammatopteris freitasii (Plate XVII, 5-8) kindly provided by R. Rössler.

Additional information has been obtained from new preparations realized for the purpose of this study in our laboratories in ChampaignUrbana and Montpellier, using the peel technique (Galtier and Phillips, 1999).

\section{Ferns with Anachoropteris-type petiole}

\subsection{Occurrences}

The genus Anachoropteris was established by Corda (1845) for anatomically preserved, isolated rachides with involuted vascular strand. Subsequently more than ten species have been attributed to this genus, ranging from the Namurian C (Early Pennsylvanian) to the Late Permian. This group of ferns, and the related Tubicaulis, Sermaya, Donnegia, Kaplanopteris, Psalixochlaena, Apotropteris, and Grammatopteris, are therefore mainly restricted to the Pennsylvanian with their latest representatives in the Permian (Table 1). A single taxon, represented by isolated petioles of Grammatopteris bertrandii, was attributed to the Early Carboniferous but its Visean age (Corsin, 1937) needs to be confirmed. As a result, the anachoropterid ferns have a shorter and more recent evolutionary history than the zygopterids which showed successive radiations in early and late Carboniferous times (Phillips and Galtier, 2005).

The oldest undisputable representative is an isolated rachis of Anachoropteris sp. illustrated by Remy and Remy (1977, fig. 49) from the Namurian C of Essen-Werden (Germany). This specimen shows a
C-shaped xylem strand with short abaxial "arms" and two widely separated adaxial protoxylem strands (Fig. 1A).

During Early Pennsylvanian (Langstettian) time, the anachoropterids show an important specific diversity reflected in the shape and degree of involuteness of the foliar xylem, in transverse section, which is either: massive with very short arms (Fig. 1B), C-shaped to nearly closed (Fig. 1C), involute (Fig. 1D), or revolute (Fig. 1E). However, this diversification/rapid radiation may be the result of collecting bias due to the rich fossil-plant assemblages of this age preserved in early Westphalian European coal balls (Galtier, 1997).

During the Late Pennsylvanian and Permian times the same variability is observable and one may suggest several morphological/ evolutionary trends:

1. "gillotii-radnicensis group" with short and thick foliar xylem and very short arms (Fig. 1B1 to B3; Plate I, 5);

2. "robusta group" with curved to C-shaped to nearly closed xylem (Fig. 1C1 to C7; Plate I, 3-4);

3. Anachoropteris williamsonii and other with involute xylem (Fig. 1D1-2; Plate I, 1);

4. "pulchra-involuta group" with revolute xylem (Fig. 1E1 to E7; Plate I, 2).

Even if it is tempting to consider the simple anatomy of the first group as primitive and the most complex one of the last group as derived, we have no evidence of this.

Considering that we have illustrated, in Fig. 1, specimens showing the maximum size known for each taxon one may recognize an increase in size within the "robusta" and the "pulchra-involuta" groups both of which extend until the Early Permian. It must be noted that the largest in the recorded data (Fig. 1C4, C7, E5-7) were preserved in cherts (clastic substrates) in contrast to most of the others from coal-ball peats.

In addition to foliar xylem shape, some precise anatomical characters are of taxonomic and evolutionary interest:

- The general shape of the xylem strand may be expressed in ratios of radial width/tangential width of the xylem strand.

- The distance between the two protoxylem strands (arrows, Plate I) on the rectilinear median region ("apolar bar") is variable; as a result, the ratio of this distance (= apolar length)/tangential width of the xylem strand also proved to be taxonomically significant (Corsin, 1937).

- The xylem thickness is generally uniform but xylem is sometimes thinner near the protoxylem strands (Plate I, 1, 2, 6). On the other hand, distal enlargement of the arms is uncommon, either just perceptible (Plate I, 4) or quite marked, resulting in club-shaped arms (Plate I, 6) in Anachoropteris clavata. Interestingly this taxon is now separated, for independent reasons, in a different genus, Kaplanopteris.

- The diameter of metaxylem tracheids is also variable and this is without relation to the xylem-strand size.

- The pinna trace is either in the form of a solid oval strand (gillotii and robusta groups) or of a U-shaped strand (williamsonii and pulchrainvoluta groups, with very rare exceptions).

- Finally, distinct foliar to cauline types of branching proved to be characteristic of some groups as demonstrated in this paper.

In the text below, the different "groups" are considered with emphasis on their vegetative morphology, including new data on branching. Information on fertile parts, ecology and habit follows.

\subsection{The Anachoropteris pulchra-involuta group}

The earliest known representative of this group with very involute/ revolute xylem arms is an unpublished specimen, "Anachoropteris laveinei" (Fig. 1E1), from the basal Langsettian/early Pennsylvanian of 
Table 1

Stratigraphic range of Anachoropteris (1-13), Tubicaulis (17-27) and related genera:

(1) Anachoropteris williamsonii (a, Truebano, Spain; b, Lancashire (First, Union) and Yorkshire, England; Bouxharmont, Belgium; Finefrau, The Netherlands and Germany; c, Katharina, Ruhr, Germany; d, Aegir, The Netherlands. see stratigraphic references in Galtier, 1997).

(2-7) Anachoropteris "pulchra-involuta group"

(2) A. pulchra (a, Radnitz, Czech Republic, Corda, 1845; b, Parker Coal, IN; c, Calhoun Coal, IL, Phillips, 1974, 1980; d, Grand-Croix, France, Corsin, 1937; e, Autun, France, Renault, 1868; f, Sardinia, Italy, Galtier et al., 2011; g, Chemnitz, Germany, Rössler, 2001).

(3) A. involuta (a, Parker Coal, IN; b, Friendsville Coal, IL; c, Duquesne, OH, Phillips, 1980; d, Calhoun Coal, IL (type specimen) Hoskins, 1930; e, Grand-Croix, France, Corsin, 1937).

(4) Anachoropteris sp. with adaxial shoots (a, Upper Path Fork Coal, EKY; b, Murphysboro equivalent Coal, IN; c, Fleming Coal, KS; d, Herrin Coal, IL, WKY; e, Baker Coal, WKY; Phillips, 1974, 1980).

(5) A. "laveinei" (Truebano, Spain, Beckary, 1988).

(6) A. gigas (Autun, France, Corsin, 1937).

(7) A. ovata (Autun, France, Corsin, 1937).

(8a-c) A. gillotii (a, Truebano, Spain, Beckary, 1988; b, Bouxharmont, Holmes, 1979; c, Grand-Croix, France, Corsin, 1937).

(9) A. radnicensis (Radnitz, Czech Rep., Corda, 1845).

(10a-c) A. robusta (a, Fleming Coal, KS; b, Calhoun Coal, IL; c, Grand-Croix, France, Corsin, 1937).

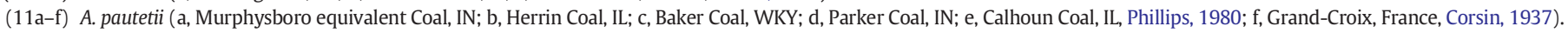

(12) A. circularis (Autun, France, Corsin, 1937)

(13) Anachoropteris sp. (a, A. sp.1. Essen-Werden, Germany, Remy and Remy, 1977; b, A. sp.2 = A. robusta? and c, A. sp.3 Bouxharmont, from Holmes and Fairon-Demaret, 1984; d, A. sp.4 Xuanwei formation, Guizhou prov. China, Hilton et al., 2004).

(14) Anachoropteris clavata (a, Parker Coal, IN; b, Friendsville Coal IL; c, Duquesne Coal, OH; d, Calhoun Coal, IL; Graham, 1935; Delevoryas and Morgan, 1954; Phillips, 1980). Kaplanopteris clavata, Duquesne Coal, OH, Tomescu et al, 2006.

(15) Sermaya biseriata (Calhoun Coal, IL, Eggert and Delevoryas, 1967).

(16) Doneggia complura (Duquesne Coal, OH, Rothwell, 1978).

(17-27) Tubicaulis

(17) T. sutcliffii (Shore, England, Stopes, 1906)

(18) Tubicaulis sp. (a, T. sp.1. Union, England, new data; b, T. sp.2. Carbon Hill Mine, Iowa, Hall, 1961; c, T. sp.3. Murphysboro equivalent Coal, IN, new data; d, T. sp.4. Herrin, Paradise,

WKY, from dichotomy of rachis, Galtier and Phillips, 1996).

(19) T. multiscalariformis (Fleming Coal, KS, Delevoryas and Morgan, 1952).

(20) T. grandeuryi (Grand-Croix, France, Galtier and Holmes, 1984).

(21) Tubicaulis sp. (Grand-Croix, France, Galtier and Holmes, 1984).

(22) T. scandens (Calhoun Coal, IL, Mamay, 1952).

(23) T. stewartii, Calhoun Coal, IL, Eggert, 1959).

(24) T. berthieri (Autun, France, Bertrand and Bertrand, 1911).

(25) T. cf. berthieri (Chemnitz, Germany, Rössler, 2001).

(26) T. solenites (Chemnitz, Germany, Cotta, 1832);

(27) T. africanus (Tanganyika, Holden and Croft, 1962).

(28) Psalixochlaena cylindrica (Truebano, Spain, Beckary, 1988; New Castle Coal Bed, Walker County, Alabama, Winston and Phillips, 1991; Union, England; Bouxharmont, Belgium, Holmes, 1977).

(29) Apotropteris minuta (Calhoun Coal, IL, Morgan and Delevoryas, 1954).

(30-33) Grammatopteris

(30) G. rigollotii (Autun, France, Renault, 1891).

(31) G. baldaufii (Chemnitz, Germany, Beck, 1920; Rössler and Galtier, 2002).

(32) G. freitasii (Pedra de Fogo Fm, Tocantins, Brazil, Rössler and Galtier, 2002).

(33) G. bertrandii (Esnost, France, Corsin, 1937).

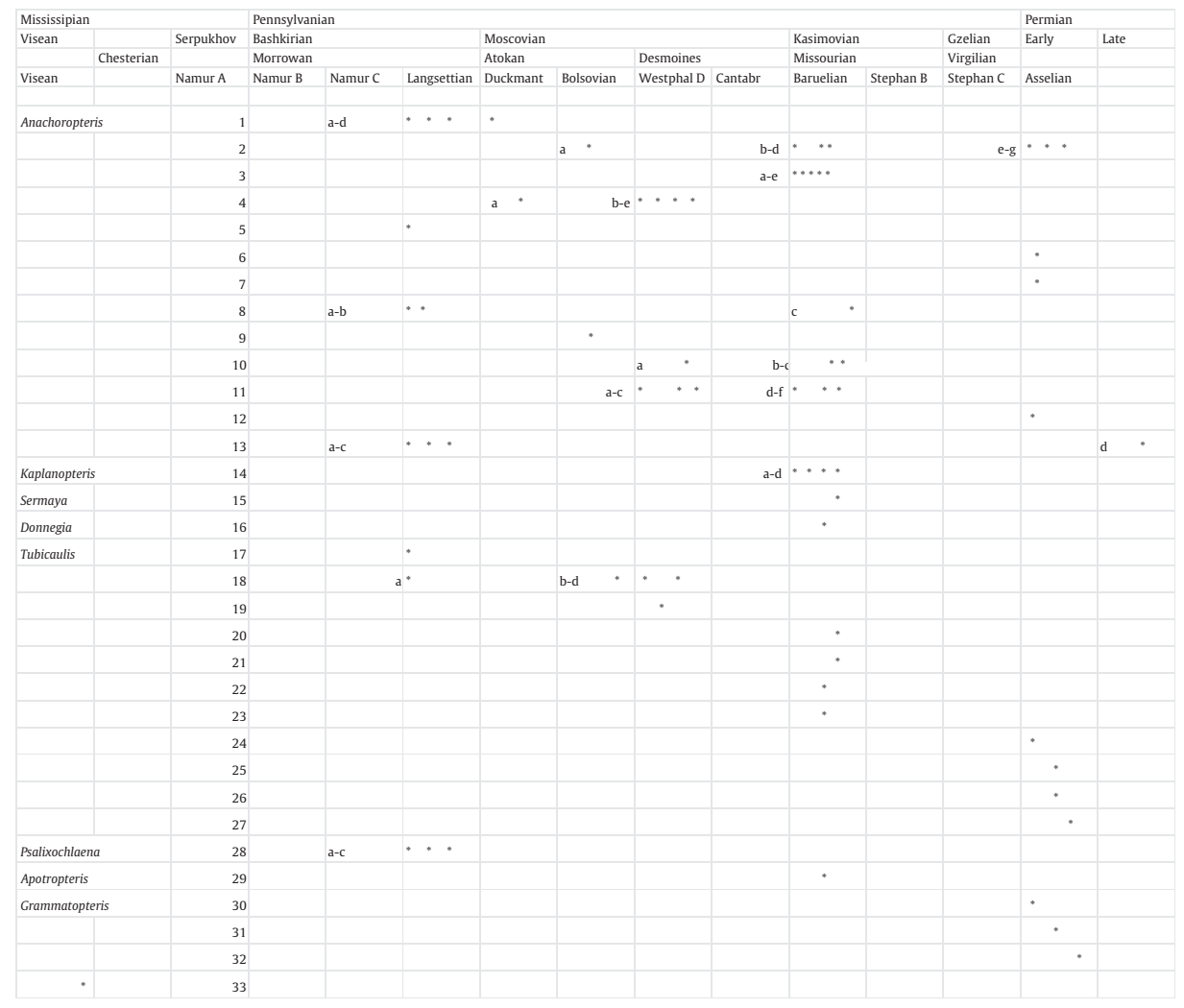




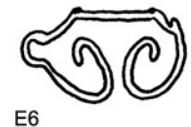

E6

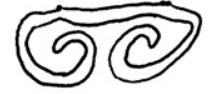

E7

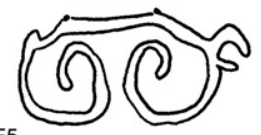

E5

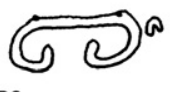

D2
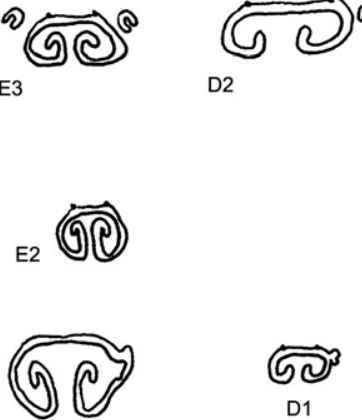

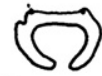

C6

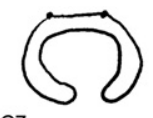

C7
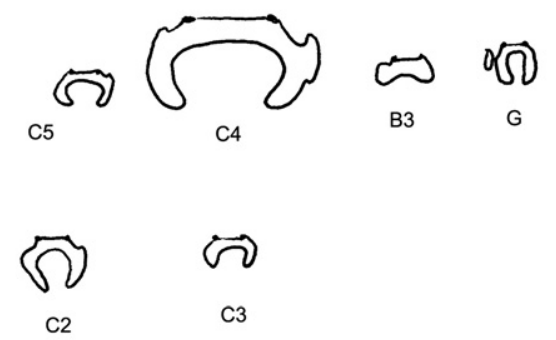

$5 \mathrm{~mm}$

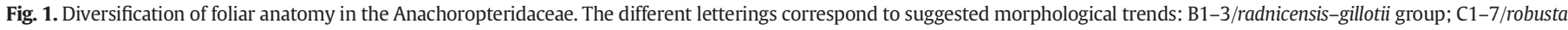
group; D-E/involuta-pulchra-williamsonii group. The taxa are broadly arranged in stratigraphic sequence:

A. Anachoropteris sp. (redrawn from Remy and Remy, 1977) Namurian C, Essen-Werden, Germany.

B1. A. gillotii (Holmes, 1979); C1. Anachoropteris sp. (Holmes and Fairon-Demaret, 1984); D1. Anachoropteris williamsonii, all from Bouxharmont, Belgium. E1. Anachoropteris “laveinei" Truebano, Spain (Beckary, 1988). F. Psalixochlaena cylindrica (Holmes, 1981a), Union, England. All Early Westphalian A-Langsettian, Early Pennsylvanian.

B2. Anachoropteris radnicensis; E2. A. pulchra (Corda, 1845) both from Radnice, Czech Rep., Westphalian C-Bolsovian/Early Desmoinesian equivalent, Middle Pennsylvanian.

C2. Anachoropteris robusta Fleming Coal, West Mineral, KS (new data); C3. Anachoropteris cf. pautetii Freeman Orient Mine 5, IL (new data); D2. Anachoropteris sp. Herrin Coal, Shawneetown, IL (new data; E3. Anachoropteris sp. twin branching, Murphysboro Coal, Cayuga, IN (new data). All Westphalian D/Desmoinesian equivalent, Middle Pennsylvanian.

B3. Anachoropteris gillotii (type); C4. Anachoropteris robusta (type); C5. Anachoropteris pautetii (type), all redrawn from Corsin (1937), Grand-Croix, France; C6. Anachoropteris robusta (new data) Calhoun Coal, IL; E4. Anachoropteris involuta (type), Calhoun, IL (redrawn from Hoskins, 1930); E5. A. involuta, Grand-Croix, France. G. Kaplanopteris (Anachoropteris) clavata (type, redrawn from Delevoryas and Morgan, 1954), Calhoun Coal, Berryville, IL. All Stephanian A/Missourian equivalent, Late Pennsylvanian.

C7. Anachoropteris circularis; E7. Anachoropteris gigas; E6. Anachoropteris ovata (types, redrawn from Corsin, 1937), all from Autun, France, Autunian/Asselian equivalent, Early Permian.

Spain (Beckary, 1988). Several species, based on rachides showing a similar anatomy, are long known from middle Pennsylvanian to early Permian time.

\subsubsection{Anachoropteris pulchra Corda, the type species}

The specimens described by Corda (1845) come from the Whetstone horizon which represents a complex of volcaniclastics in the Radnice group of coals (Czech Republic); they are considered as Middle Pennsylvanian (Bolsovian) in age (Oplustil et al., 2009). One small rachis (about $2.7 \mathrm{~mm}$ diameter) was described and, very accurately, illustrated by Corda (1845, Plate 56, figs. 1-2). This section (one polished surface) showing the characteristic strongly involute xylem anatomy, dense cortex and presence of hairs, is illustrated on our Plate II, Fig. 1. Another section of the same rachis (Plate II, 2) is above the departure of subopposite pinna trace; the trace on the left is O-shaped. Kubart (1916, Plate VII, figs. 49-51) illustrated other sections, unfortunately not found, showing earlier stages of incipient pinna trace. We agree with Corsin (1937) to consider this O-shaped trace as a feature of taxonomic significance. Smaller rachides, about $1.5 \mathrm{~mm}$ in diameter showing a C-shaped, just involuted, xylem strand (Plate II, 3), have been described by Corda under the name of Anachoropteris rotundata, but they probably correspond to secondary rachides of Anachoropteris pulchra. It is worth mentioning that Chorionopteris lamina with synangia was considered as fertile parts of A. pulchra (Kubart, 1916); however, the reinvestigation of the original material did not allow us to recognize any organic connection. It is suggested that Chorionopteris represents reproductive parts of scolecopterids belonging to one of the associated marratialean Psaronius plants.

Following Corda, Renault (1868) attributed to Anachoropteris pulchra some rachides from the Early Permian of Autun possessing a similarly involute xylem strand; the same identification was proposed by Corsin (1937), Phillips (1974, 1980), Rössler (2001) and Galtier et al. (2011) for rachides from, respectively, the Late Pennsylvanian of France and the U.S.A., and the Early Permian of Germany and Sardinia (Table 1:2). All these rachides are younger and much broader (up to 5-8 $\mathrm{mm}$ in diameter) than the A. pulchra type from Radnice. Some of them possess a ratio of radial/tangential width of xylem strand about 0.8 , similar to that of the type species. However, in most cases this ratio is smaller and the shape of the revolute xylem strand is significantly different; therefore, such specimens are distinguished as Anachoropteris involuta and Anachoropteris ovata. The last species is characterized by a departing $\mathrm{O}$-shaped pinna trace resulting from the separation of a prominent loop of the lateral arm (Plate I, 2), and by tracheids smaller than those of $A$. involuta (Plate II, 4). The Early Permian A. ovata may be considered as a derived member of the "pulchra-involuta group". 

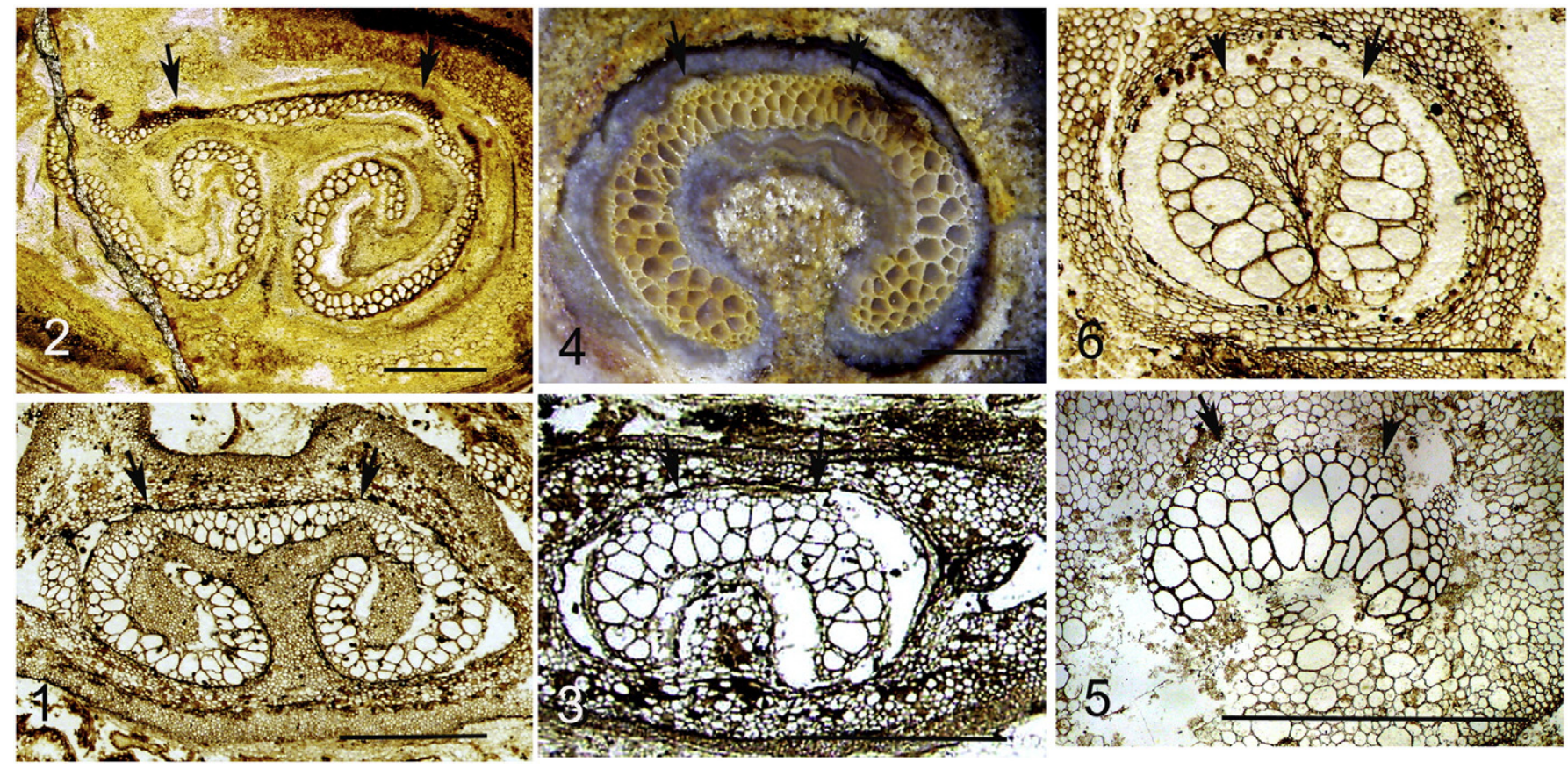

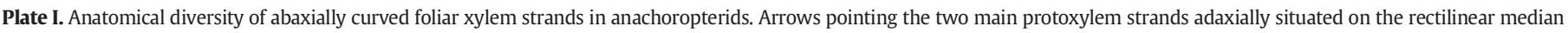
"bar". All transverse sections and scale bars $=1 \mathrm{~mm}$.

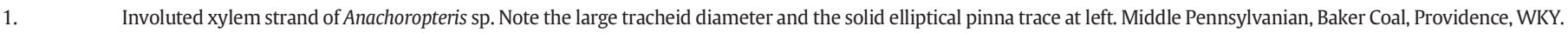
UI40201EBOT-52.

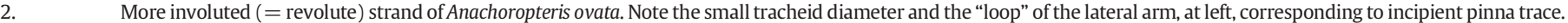
Early Permian, Autun. MNHNP 2237 Renault 105.

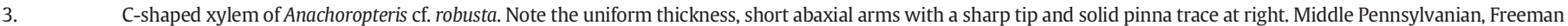
Orient Mine 5, IL. UI3217CTOP-62.

4. C-shaped xylem strand of Anachoropteris circularis. Note the very long xylem arms with slightly enlarged tips. Early Permian, Autun. MHNA 94 DLC.

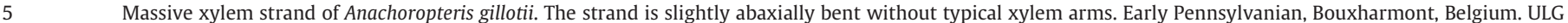
BX695A1ABOT 96.

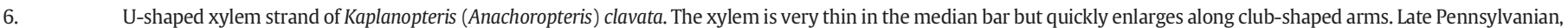
Calhoun Coal, Berryville, Illinois. UI1168CTOP-7.

\subsubsection{Late Pennsylvanian Anachoropteris involuta, with lateral shoot}

Anachoropteris involuta was founded by Hoskins (1930) on a rachis, 6.5-7 $\mathrm{mm}$ in diameter, from a coal ball from the Calhoun Coal, Illinois (Late Pennsylvanian, Missourian, Barruelian equivalent). Reexamination of the type material by one of us (TLP) confirmed the rather poor preservation mentioned by Hoskins. However, the slide sequence showed stages in lateral extra-marginal development of pinna-trace formation that is similar to those reconstructed by Corsin (1937, figs. 34-35) and later illustrated by Phillips (1974, figs. 44-45). Therefore, A. involuta differs from Anachoropteris pulchra in its pattern of emission of an U-shaped pinna trace and in the smaller ratio of radial/tangential width of xylem strand; these are arguments to segregate the two species (compare Figs. 4 and 5 with 1 and 2 on Plate II).

Our understanding of Anachoropteris involuta has been based on Corsin's (1937) detailed investigation of material from cherts of the Late Pennsylvanian (Barruelian equivalent) of Grand-Croix, France. Most of the rachides/petioles examined by Corsin are 6-8 $\times 3-4 \mathrm{~mm}$ in diameter with a xylem strand about $4 \times 2 \mathrm{~mm}$. The departing primary pinna trace is U- then C-shaped (PT, Plate II, 4-5); detached primary pinna rachides are $2.5 \times 1.5 \mathrm{~mm}$ wide, with a $\mathrm{C}$-shaped xylem strand; and supposed secondary pinna rachides are a little more than $1 \mathrm{~mm}$ broad with a small C-shaped xylem. The same author also described precocious traces ("sorties hâtives") inserted at the base of primary pinnae and therefore homologous to secondary pinnae. They are solid traces $(250-300 \mu \mathrm{m})$ constituted of very small tracheids. The first is detached from the outside (catadromic side) of the very proximal region of the U-shaped pinna trace; the second trace is detached higher up to the inside (anadromic). Corsin (1937, Plate 28: 2, 4) demonstrated that the first trace was entering an organ detached from the pinna base, extending in a horizontal plane, and recurved towards the adaxial face of the main rachis. Due to this strange morphology, and by analogy with those organs found in a similar position at the base of pinnae in some zygopterids and ankyropterids, Corsin designated them as "aphlebiae"; however, he did not reconstruct the morphology of these organs. We have no evidence of laminate pinnules belonging to this species.

At least three distinct branching types in the development of shoots on fronds have been mentioned by Phillips (1974) within the Anachoropteris involuta group but only one is known for the Late Pennsylvanian members. Pinnately compound fronds of $A$. involuta bearing protostelic shoots laterally have been illustrated by Hall (1961) and Phillips (1974) for late Pennsylvanian rachides from Berryville, Illinois. Such a rachis shows a small cauline stele (white arrow, Plate II, Fig. 6) still attached to a U-shaped pinna trace in the form of a common trace. Right above this trace the cellular continuity of the rachis cortex with an adjacent protostelic stem (S, Plate II, 6) is visible. The last organ represents a recurved shoot bearing immediately many large roots. One must note the spectacular increase in diameter of the cauline stele by comparison with the most proximal cauline component of the departing common trace. Furthermore, there is evidence of one incipient petiole trace (IP, Plate II, 6) borne on this shoot.

It is significant that the same type of foliar to cauline branching was described in a contemporaneous Late Pennsylvanian Anachoropteris involuta from France (Galtier and Holmes, 1984). These authors provided a reconstruction (reproduced here Fig. 2 ) of the shoot laterally borne on the rachis and quickly recurved. In this case also the cauline stele was 
proximally attached to a pinna trace. The stem, followed over $2 \mathrm{~cm}$ length, increased in diameter up to $12 \mathrm{~mm}$ while the cauline protostele was described as a vitalized protostele with files of xylem parenchyma. Very numerous roots occur all along the stem and the emission of several helically arranged leaf traces has been documented. The leaf trace, initially bar-shaped, becomes abaxially curved. In the free petiole the foliar xylem strand is in the form of an open C-shape about $1.6 \mathrm{~mm}$ wide, i.e. much smaller and very different from the involuted xylem of the parent rachis. Considering similarities in stelar organization, leaf trace emission, petiole anatomy, and overall size and organization, this epiphyllous shoot was interpreted as conforming to the diagnosis of Tubicaulis stewartii Eggert (1959) from the Late Pennsylvanian of Illinois.

\subsubsection{Middle Pennsylvanian involute Anachoropteris, with adaxial shoots}

The diversity of Middle Pennsylvanian age Anachoropteris (C2-3, D2, E3, Fig. 1) is documented only from American coal-ball material. This variability includes rare rachides with very involuted/revoluted xylem (Plate III, 1-2) which are similar to Anachoropteris involuta, particularly in the pattern of U-shaped pinna-trace formation (compare Plate III, 1 with $A$. involuta on Plate II, 4). In this example there are paired pinna traces and then strictly opposite primary pinnae (PP, Plate III, 2) with a trace becoming C-shaped. This section is of particular interest in showing also vascular strands and oblique sections of the base of two "precocious" secondary pinnae (SP) situated on the acroscopic side. If these secondary pinnae are the first borne this is a difference with A. involuta where Corsin (1937) demonstrated that the first secondary pinna ("aphlebia") was catadromous. However, there is the possibility that the first precocious pinna was born on the basiscopic side and was either missed or destroyed.

Most Middle Pennsylvanian Anachoropteris rachides are once involuted (i.e. not revoluted like Anachoropteris involuta). They produce U-shaped primary pinna traces like those illustrated on Plate III, fig. 3 but more rarely they possess a solid oval pinna trace (Plate I, 1). Foliar branching has been observed in detail. The large rachis, at left on Plate III, fig. 3, shows the base of one primary pinna with U-shaped trace (arrow) and one small trace (SPT) to a secondary pinna situated on the acroscopic side. In opposite position there is a short expansion of the pinna base cortex suggestive that the first secondary pinna was actually attached here, i.e. in basiscopic (catadromous) position. By analogy with Corsin's observation it is suggested that the distal portion of the aphlebia-like secondary pinna corresponds to the small rachides (SP) extending along the adaxial side of the main rachis. One free primary pinna rachis (PP, Plate III, 3) is up to $3 \mathrm{~mm}$ in diameter; its xylem strand remains U-shaped and shows swollen arms, two characters distinguishing it from the primary pinna of $A$. involuta. The upper region of this rachis shows one recurved expansion interpreted as the base of a secondary pinna; this is supported by the two small traces (SPT, TPT) which are the probable vascular strands of secondary and tertiary pinnae. One isolated, probable secondary rachis (SR, at the bottom of the figure), shows branching traces but evidence of lamina is missing. Partial reconstruction of the basal region of such a secondary rachis (recurved and aphlebialike) is proposed on the left part of Fig. 3.

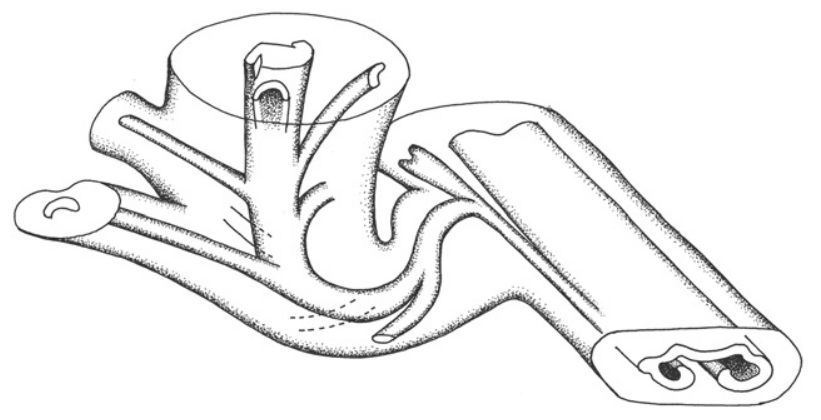

Fig. 2. Reconstruction of an epiphyllous shoot borne laterally on a rachis of Anachoropteris involuta from the Late Pennsylvanian of Grand-Croix, France. The strongly recurved protostelic stem bears numerous C-shaped, small petiole traces.

Modified from Galtier and Holmes (1984).

As first mentioned by Phillips (1974) these Middle Pennsylvanian Anachoropteris rachides commonly bear adaxial protostelic shoots. This feature is well documented in the specimen on Plate III, fig. 4 that shows, adaxially from the median region of the rachis, the buildup of tracheids into a cauline trace. The obliquely sectioned cortex of the shoot, with outgoing roots (R), is visible just above. On Plate III, fig. 5 the main foliar member is seen in perfect transverse section while the cauline trace departure is shown in longitudinal section with roots $(R)$ right from the base; serial sections indicate that the shoot is first borne perpendicularly to the parent rachis and then markedly reflexed. The rachis is also emitting a primary pinna trace laterally (PT, Plate III, fig. 5). The reconstruction in Fig. 3 is based on this specimen showing, in the forefront, xylary organization of the rachis bearing a pinna trace at left, as well as an adaxial shoot becoming recurved and bearing petiole traces. In the background the cortical tissues of the rachis are represented with the traces of the primary pinna and of the two basal secondary pinnae. The resulting small (aphlebia-like) secondary pinnae arch over the adaxial face of the main rachis. This arching over of secondary pinnae across the adaxial face of the rachis is common and may represent a means of hooking and support for leaning or climbing fronds. For simplicity all adventitious roots have been omitted from the drawing. Another example of a rachis bearing both a pinna trace and a recurved shoot is shown on Plate IV, 1.

In addition, even small foliar members bear shoots, as illustrated by the rachis of Plate IV, figs. 2-3. This rachis is interpreted as a primary pinna, considering its small size and the U-shaped xylary configuration with swollen arms similar to those shown in the primary pinna of Anachoropteris sp. (e.g. PP, Plate III, 3). The incipient adaxial cauline trace is seen in C, Plate IV, fig. 2 while on a subsequent section (Plate IV, 3 ) the stele of the small stem, curved upward, is twice sectioned.

Another branching type in the development of shoots on fronds is illustrated on Plate IV, 4-7 and reconstructed on figs. 4-5. The specimen on Plate IV, 4 is a transverse section of a distorted rachis showing proliferation of small tracheids $(S)$ in the median region of the involuted xylem strand and separation (arrow) of the xylem arm on the left side. The section higher up (Plate IV, 5 ) differs by the increasing proliferation of the cauline tracheids in the median region. More distally

Plate II. Rachides of the "pulchra-involuta group" showing the characteristic very involute/revolute xylem strand. All transverse sections and scale bars = 1 mm. cortex and hairs (H). NMP, Corda coll. E212aBOT.

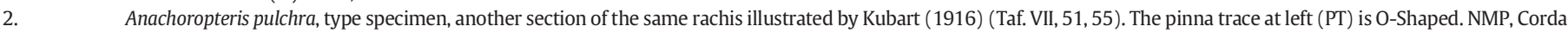
coll. E212aTOP.

3. Anachoropteris pulchra, probable second order rachis with less involute xylem strand. NMP, Corda coll. E214cTOP.

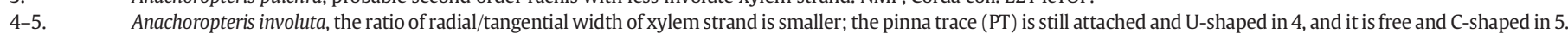
Late Pennsylvanian, Grand-Croix, France. 4 = UM2 GC514AT01; 6 = SMNHS Florin coll. 3426.

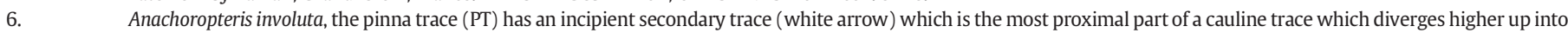
the coalescent stem $(\mathrm{S})$. The diameter of the cauline protostele quickly increased, showing a departing petiole trace (IP). Several large roots (R) are detached from the very proximal region of the shoot. Late Pennsylvanian, Calhoun Coal, Berryville, IL. UI22931 1301LTOP-1. 

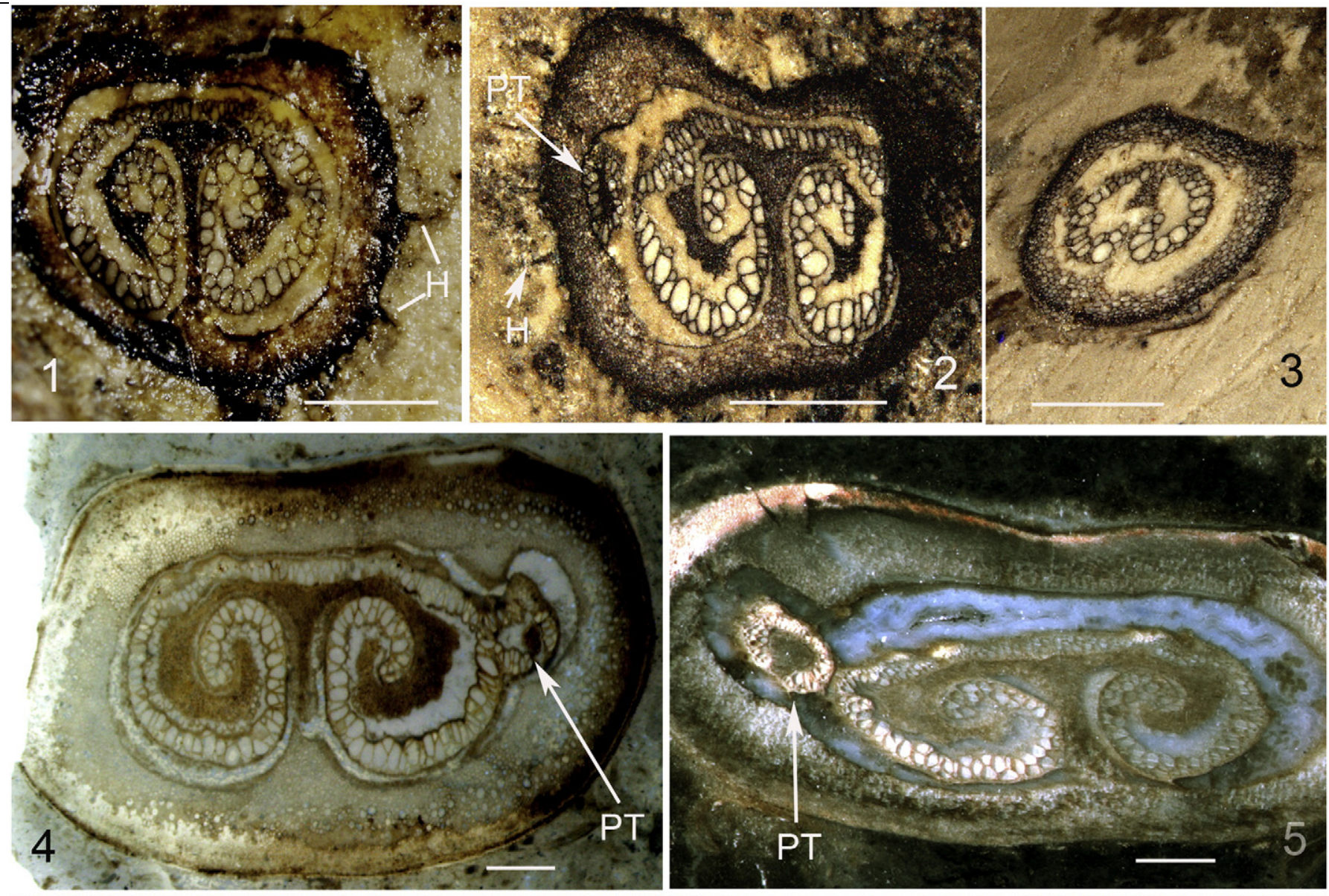

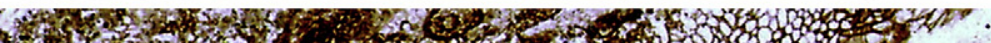

H.

7.7.

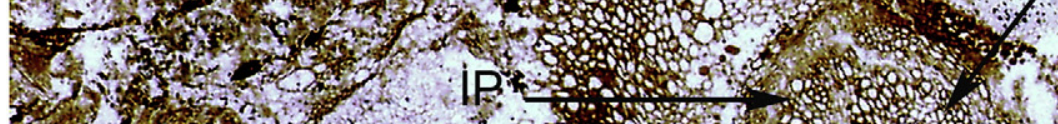

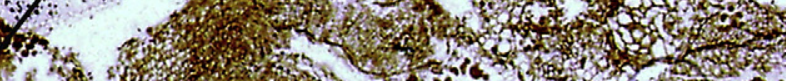

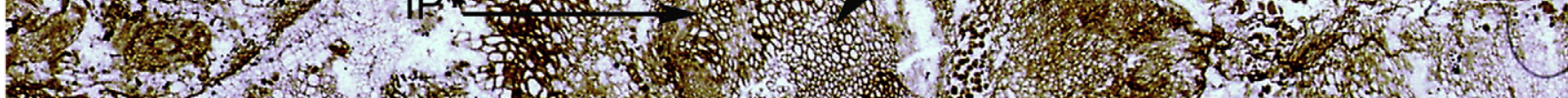

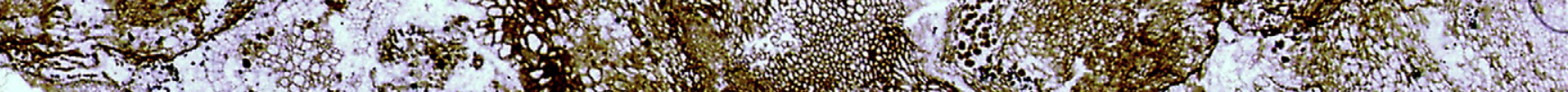

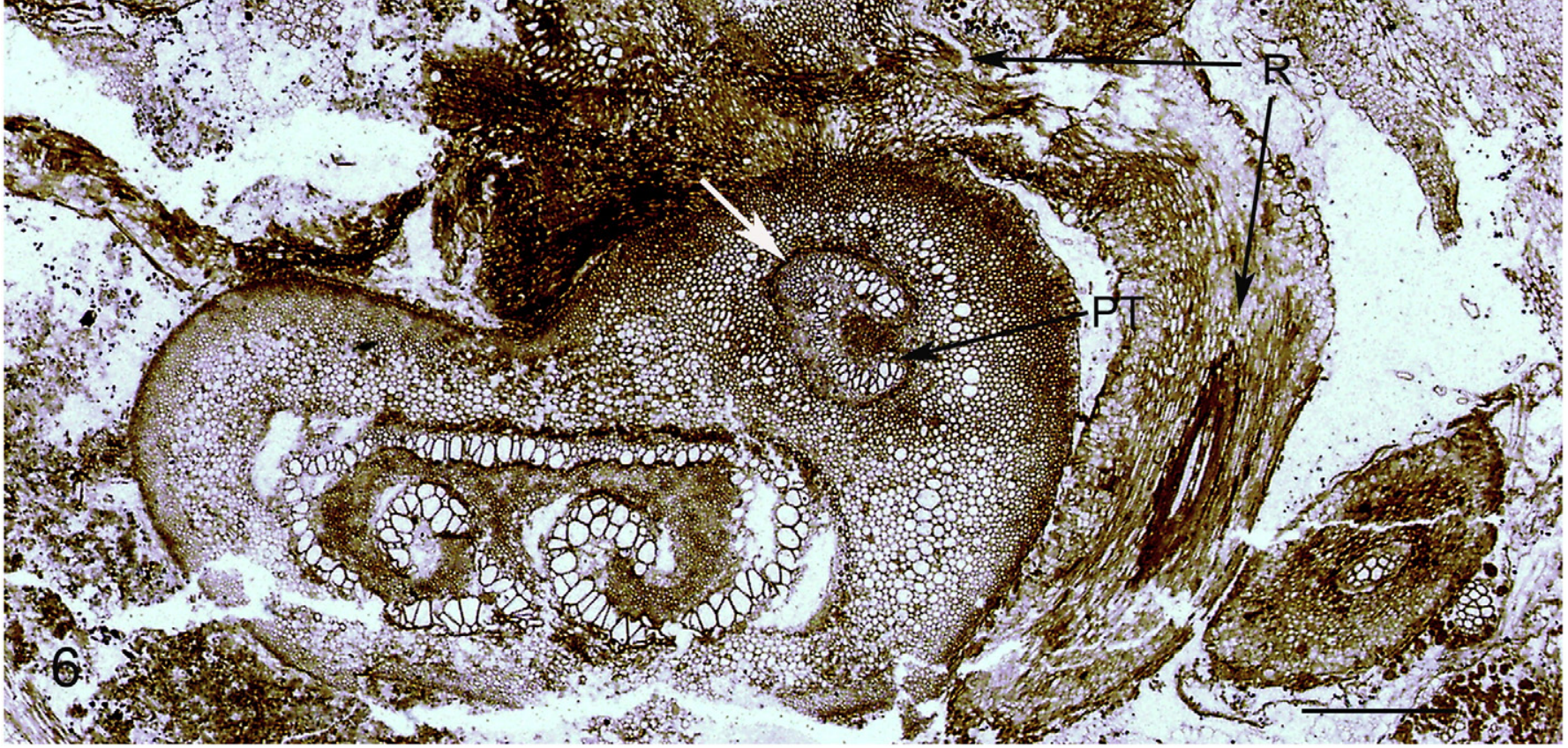


(Plate IV, 6) this rachis seems to divide into two lateral foliar members (F1 and F2) and one median cauline siphonostele (S). At this stage there is still a common cortex cloaking the two foliar organs. The foliar member F1 was greatly compressed with its xylem obliterated while the xylem of foliar member F2 is in the form of a "ring" clearly derived from the right side inrolled arm of the original anachoropterid strand. This circular xylem strand is actually thicker abaxially with a double row of large tracheids interpreted as the result of flattening of the previously inrolled tip of the xylem arm; on the opposite adaxial surface small protoxylem tracheids are visible. Another specimen, shown on Plate IV, fig. 7, is interpreted as a little more distal region of the same type of branching. The siphonostelic cauline trace is departing upward on the adaxial side and both foliar members show well preserved xylary strands with bilateral symmetry and protoxylem groups on the adaxial side. However, F1 shows an internal bar separated from the xylem ring while in F2 the bar is contiguous with the lower part of the ring; the last anatomy is very similar to that of F2 in Plate IV, fig. 6. At this stage both foliar members still possess a common cortex. Another example of a most distal section (Plate V, 1) was beyond the recurved cauline stele, and foliar members are fully separated; anatomy of one foliar member (arrow at left) appears unchanged while there are two involuted xylary strands (a dichotomy) at right (double arrows). Finally, this foliar to cauline branching type may be interpreted as a trifurcation (two close branchings) of the involute foliar member producing one median siphonostelic cauline shoot, departing adaxially, and two lateral foliar members with initially circular xylem strands. The reconstruction in Fig. 4 (not taking in account the first branching, i.e. the separation of the compressed foliar member F1) shows the second branching, i.e. the separation of the cauline siphonostele and of foliar member F2. The reconstruction in Fig. 5 tracks all 3 members ( 2 foliar and the median cauline) in a more distal region of the trifurcation.

The last branching type in the development of shoots on fronds is interpreted as a dichotomy of the main involuted foliar member resulting in a cauline siphonostelic trace (Plate V, 2-3). As the cauline stele $(S$, Plate $V, 2$ ) begins to form petiolar traces, the remaining half of foliar xylem (F, Plate $\mathrm{V}, 2$ ) progressively recurves toward a $\mathrm{C}$ to involute shape. At this stage both xylem strands are within a common cortex. Higher up (Plate V, 3) the siphonostelic cauline stele enlarges and its pith shows ground tissue similar to that inside the petiolar traces.

\subsection{Early Pennsylvanian Anachoropteris williamsonii}

This fern was first described by Williamson (1878) under the name of Rachiopteris gleiche from British coal balls, then as Rachiopteris rotundata by Felix (1886) from Westphalia. Subsequently, it was attributed to the genus Anachoropteris by Scott (1920) and distinguished as a new species, Anachoropteris williamsonii, by Koopmans (1928). Corsin (1937) provided a detailed specific diagnosis. Holmes (1981b), studying new British and Belgian material, first described the evidence of foliar to cauline branching in this species.

Anachoropteris williamsonii is of relatively rare occurrence and restricted to Early Pennsylvanian coal balls from west Europe (line 1, Table 1) ranging from the basalmost Langsettian of Spain, England, Belgium, The Netherlands and Germany up to the basal Duckmantian of The Netherlands.

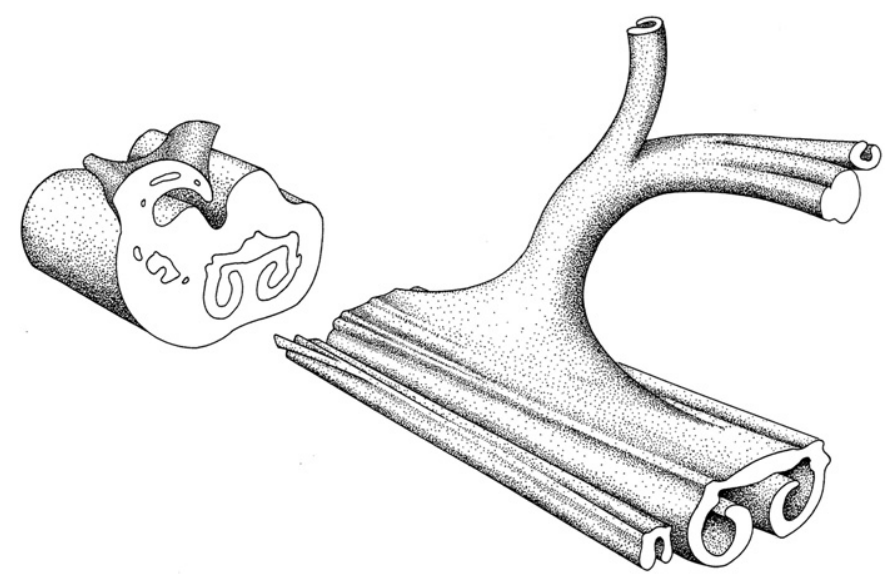

Fig. 3. Reconstruction of Anachoropteris sp. foliar member with protostelic adaxial shoot from the American Middle Pennsylvanian. The rachis is also emitting a lateral pinna trace which is shown with paired small lateral secondary pinna traces. Note how the resulting small pinna arches over the adaxial face.

The main rachis is small, about $4-5 \times 3 \mathrm{~mm}$ in transverse section, and the maximum diameter of $8 \mathrm{~mm}$ mentioned by Corsin (1937) seems greatly overestimated. The primary xylem strand, about $2 \times$ $1 \mathrm{~mm}$ (Plate VI, 1-3), is in the form of a slender involute arc only 1 or 2 tracheids thick. Metaxylem tracheids are up to 150-200 $\mu \mathrm{m}$ diameter; they exhibit reticulate thickenings to multiseriate scalariform pitting. There are two protoxylem strands on the median rectilinear adaxial face, separated by more than $1 \mathrm{~mm}$. The successive stages of pinnatrace formation may be followed on Plate VI, figs. 3 and 2; they consist of marginal development of U-shaped traces. This is conforming to observation by Holmes (1981b) while Corsin (1937) erroneously described a massive pinna trace. Primary pinnae are borne alternately (Plate VI, 3) to sub-oppositely (Plate VI, 2). In the pinna base the Ushaped xylem strand is about $300 \times 150 \mu \mathrm{m}$ broad and it shows the precocious emission of a small cylindrical trace (arrow, Plate VI, 5) less than $100 \mu \mathrm{m}$ diameter; this is the trace of the first second order pinna borne on the outer (catadromic) side which is becoming free (SP, Plate VI, 1) as a structure recurved towards the adaxial side of the main rachis. The primary pinna rachis is about $1 \mathrm{~mm}$ diameter at its base and it quickly divides (PP, Plate VI, 1 and 4) giving rise, on the inner (anadromic) side, to another secondary pinna rachis (SP, Plate VI, 1 and 4). The latter small rachis is cylindrical, about $0.7 \mathrm{~mm}$ in diameter, with a broad homogeneous cortex and a tiny apparently cylindrical xylem strand. We have not obtained information on either more distal branching of these secondary pinnae or evidence of lamina, but this is suggestive that the Anachoropteris williamsonii frond was at least tri-pinnate.

The occurrence of shoots on foliar members of Anachoropteris williamsonii was first mentioned by Holmes (1981b) from two specimens illustrated here. One Belgian specimen of Anachoropteris shows the initial enlargement of the xylem strand median region due to the proliferation of small tracheids (arrow, Plate VII, 1); higher up a trifurcation results into a middle trace, in the form of a solid, more or less cylindrical, protostele (S, Plate VII, 2), and two lateral, circular xylem strands (F1-2, Plate VII, 2), each corresponding to one of the previous enrolled

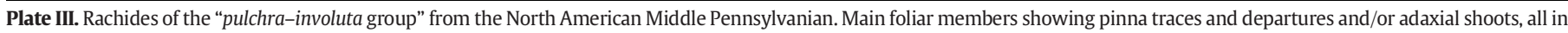
cross sections. Scale bar $=1 \mathrm{~mm}$.

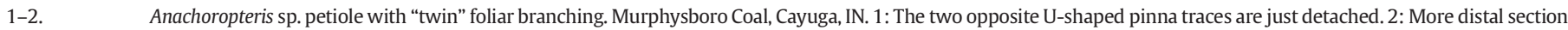
of the same showing the bases of primary pinnae (PP) and of truncated secondary pinnae (SP) with their small trace. UI25760DBOT-2 and $25760 \mathrm{ETOP}-54$.

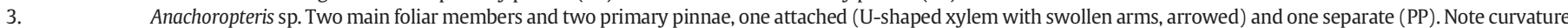
of secondary pinna (SP) extending over adaxial surface of main rachis at left. SR, detached secondary pinna rachis; SPT, TPT, secondary and tertiary pinna traces. Baker Coal, Providence, WKY. UI8222BBOT-52.

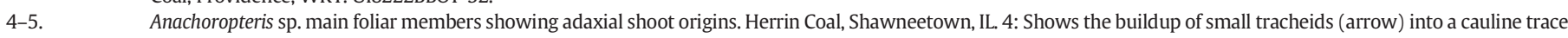
and roots (R) above in shoot cortex. UI3123DBOT-30.5: Shows the cauline trace departure in longitudinal section with roots (R), the rachis is also emitting a pinna trace (PT) laterally. UI slide 4133-7966BTOP-10. 
xylem arms. The median bundle is about $1 \mathrm{~mm}$ in diameter and the two lateral ones are twice as large. At this stage the three xylem strands are still within a common ground tissue and higher up (Plate VII, 3 ) they become free. The median strand, interpreted as a cauline stele, has been followed over a distance of $9 \mathrm{~cm}$; its diameter rapidly increased, then remained constant around $1.7 \mathrm{~mm}$. The protostele consists only
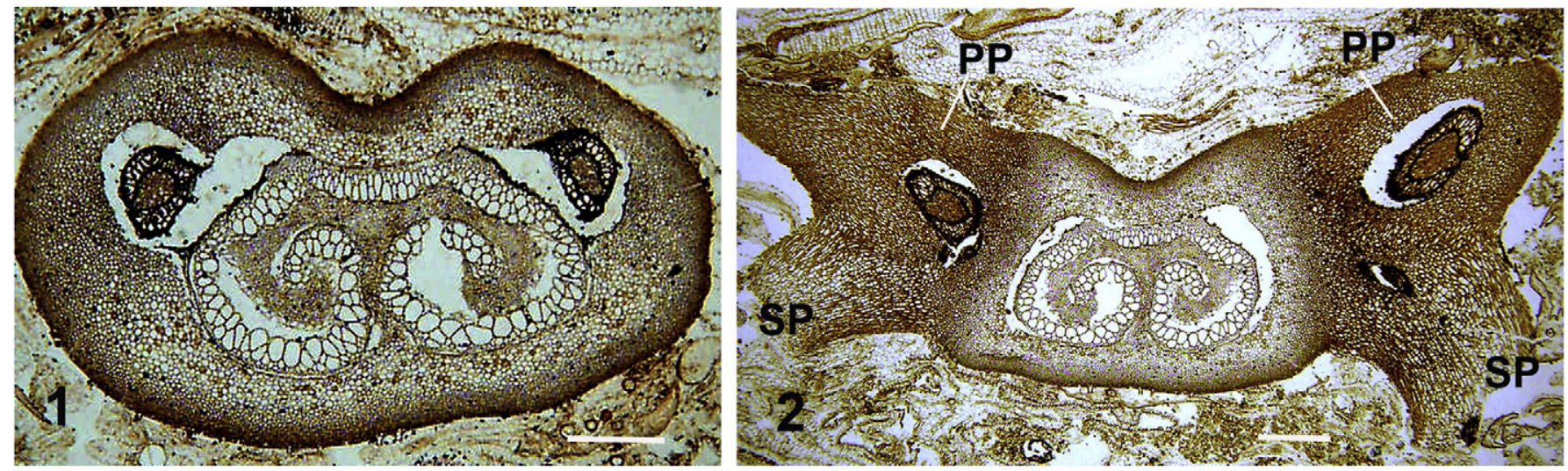
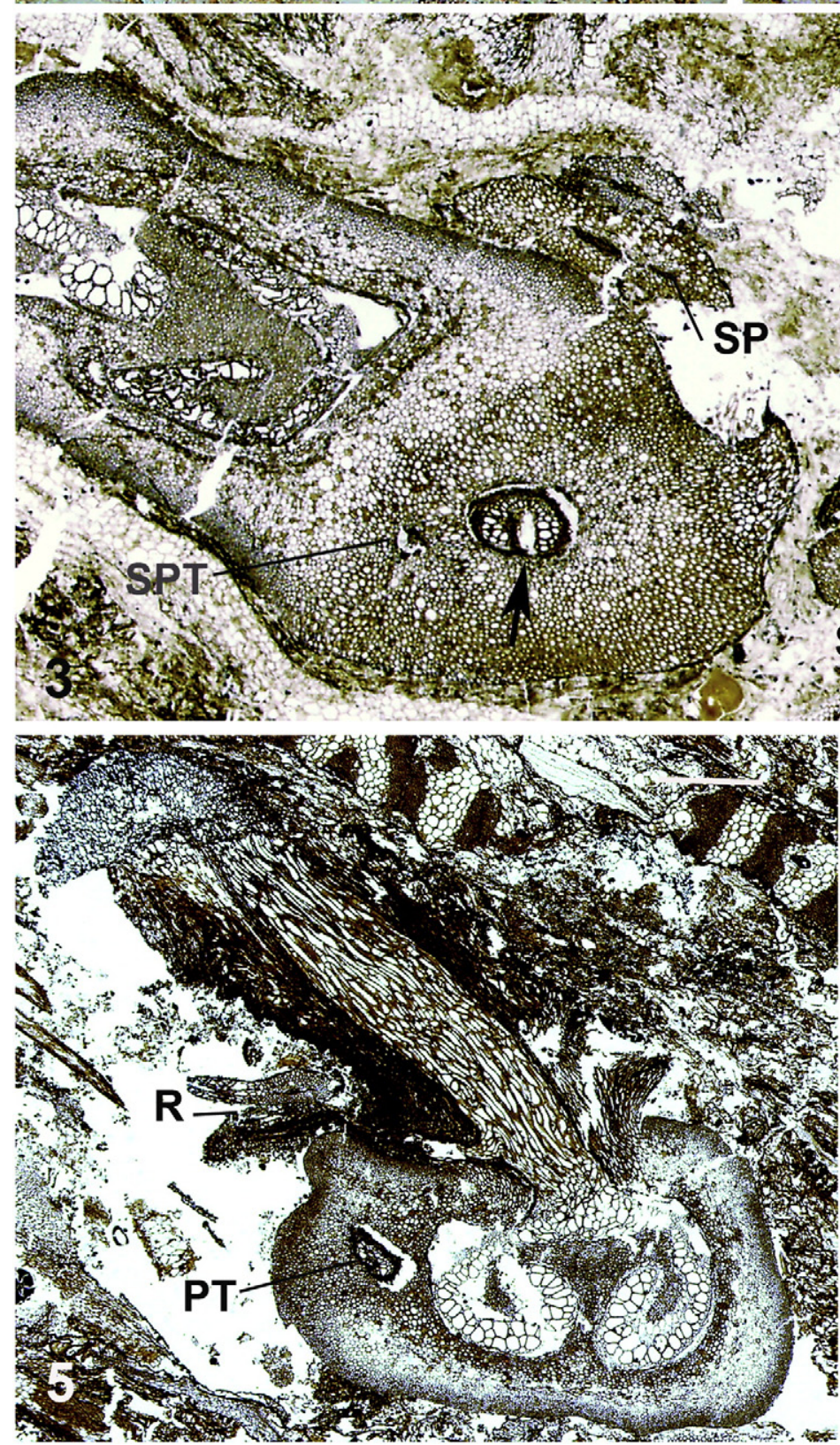

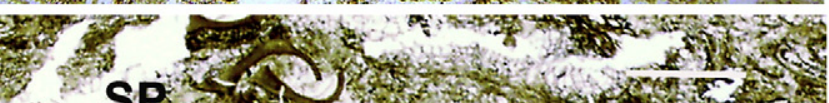

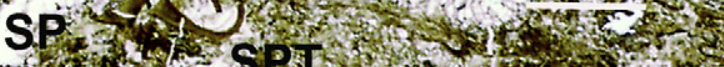

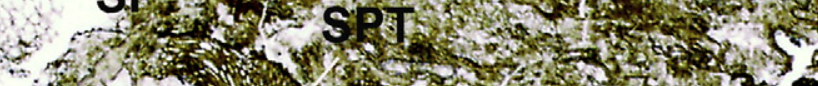

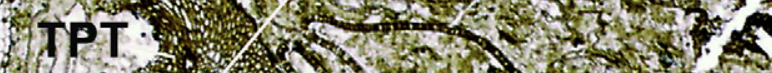

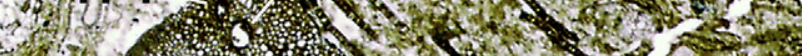

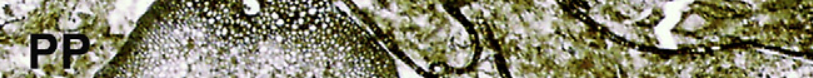

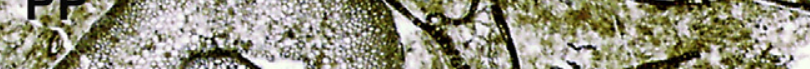

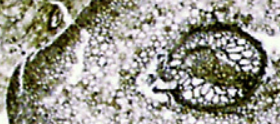
6

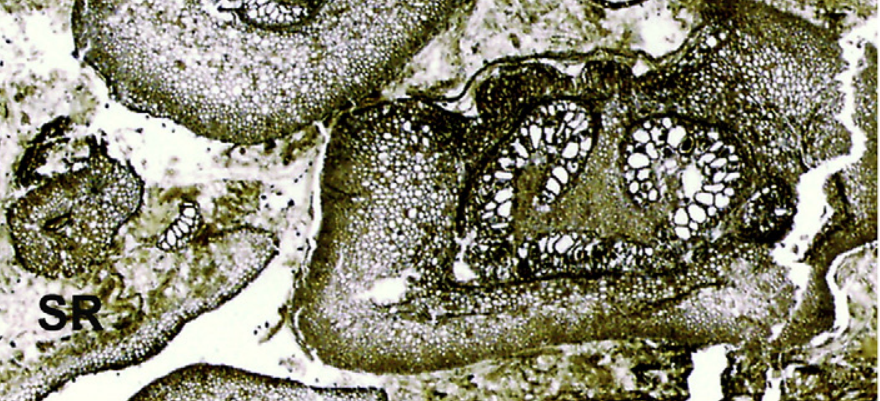

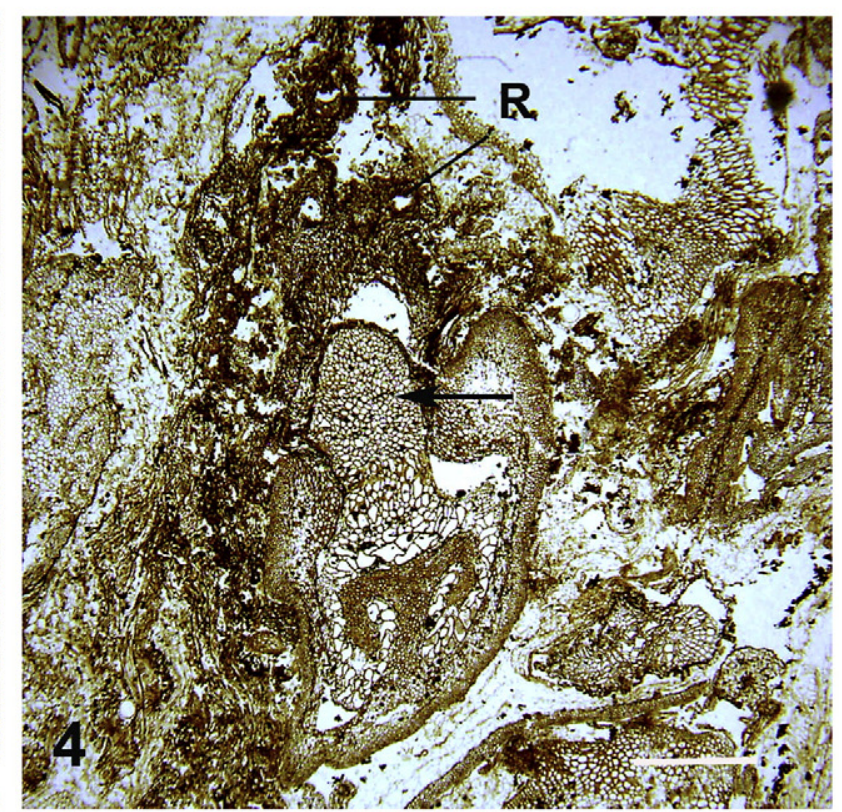


of tracheids, about $100 \mu \mathrm{m}$ in diameter with some broader in the central area. The cauline stele shows the emission of several helically arranged petiolar strands which are initially bar-shaped then slightly curved abaxially (PT, Plate VII, 3). Two protoxylem strands are visible on the adaxial face of one incipient bar-shaped leaf trace (IPT, Plate VII, 3). The stem cortex is incompletely preserved but broad cells are commonly distributed within the middle parenchymatous region. One of the two lateral organs resulting from the trifurcation (F2, Plate VII, 3 ) is well preserved and illustrated in detail on Plate VI, 6. It is circular in cross section, about $3.5 \mathrm{~mm}$ diameter with a cortex of very small cells at the periphery and larger ones in the middle region. The circular xylem strand $(1.4 \times 1.2 \mathrm{~mm})$ is slightly dorsiventral with two groups of small tracheids (probable protoxylem strands) on the adaxial face (arrows, Plate VI, 6). The other tracheids, up to $200 \mu \mathrm{m}$ broad, are similar to those of the initial Anachoropteris trace. The central area is occupied by small sclerotic cells which correspond histologically to the inner ground tissue seen within the involute arm of Anachoropteris. Interestingly, roots $(R$, Plate $V I, 6)$ are emitted in the proximal region of these organs. These strange structures, interpreted as foliar, are only preserved for a very short distance. Therefore, this Belgian specimen clearly documents the trifurcation of a rachis of $A$. williamsonii resulting in the production of a middle epiphyllous shoot in the form of a protostelic cauline organ arising adaxially as reconstructed in Fig. 6.

A second specimen of the same age, found in a British coal ball (Union Seam, Burnley, Lancashire) confirms this branching. In this example the most proximal region is very poorly preserved; however, in sections just beyond the trifurcation (Plate VII, 4 and 5) one can recognize the massive cauline protostele $(\mathrm{S})$ flanked by the two circular xylem strands (F1-2). The cauline stele is recurved (Plate VII, 4) and cut twice in another section with the evidence of a first petiole trace departure (Plate VII, 5). The protostele is preserved for more than $12 \mathrm{~cm}$; its diameter increases from 1 to $1.6 \mathrm{~mm}$ and parenchyma cells become intermixed with tracheids in the distal region (Plate VII, 6). Numerous massive leaf traces are borne helically on the stem and they soon acquire a slight abaxial curvature. Unfortunately, the stem cortex is mostly destroyed. As in the Belgian specimen, it was not possible to follow, beyond a few $\mathrm{mm}$, the two organs with circular xylem resulting from the trifurcation; in one of them (F1 on left, Plate VII, 4) the xylem is $1 \mathrm{~mm}$ in diameter and thicker on one side with protoxylem strands on the other side, suggesting a bilateral symmetry of foliar nature. The cortex is relatively well preserved with scattered large cells and the free organ is about $4 \mathrm{~mm}$ in diameter, as in the Belgian specimen.

In conclusion, we have the evidence of epiphyllous shoots borne, in both cases, on an Anachoropteris williamsonii rachis. According to the anatomy of their protostele and of their massive, rectangular then C-shaped leaf traces, these stems conform to the genus Tubicaulis. They represent a new example of shoots borne on foliar members of anachoropterid ferns. As reconstructed in Fig. 6, in A. williamsonii the shoot results from a trifurcation of the rachis into two lateral foliar members and a median adaxial stem, as in the American Middle Pennsylvanian Anachoropteris described just above; differences concern the protostelic versus siphonostelic cauline trace and the absence versus presence of internal bar in the circular xylem of the two resulting foliar members. This may be an argument to consider the Middle Pennsylvanian anachoropterids as derived members of the same group as the Early Pennsylvanian A. williamsonii.

The Tubicaulis-type of stems borne on Anachoropteris williamsonii rachides are comparable to several species of Tubicaulis previously described from the Pennsylvanian. The stem protostele is solid in the Belgian specimen but it is ranging from solid to mixed in the English shoot and this difference may be ontogenetic. As a result, the first one was considered by Holmes (1981b) as similar to Tubicaulis scandens (Mamay, 1952) while the second was compared to Tubicaulis stewartii (Eggert, 1959) and Tubicaulis multiscalariformis (Delevoryas and Morgan, 1952). One unnamed species of Tubicaulis from the early Westphalian of England was mentioned by Millay (1970) who noted similarities with $T$. stewartii and T. multiscalariformis. This stem is illustrated for the first time on Plate VII, fig. 7. This isolated stem with a mixed protostele probably represents the distal part of the same taxon represented in Figs. 4 to 6 of the same plate. Of interest, this specimen shows free petioles (P, Plate VII, 7) with a C-shaped but not enrolled xylem strand, therefore distinct from the A. williamsonii rachis anatomy. Isolated rachides with the same anatomy occur in Bouxharmont coal balls and they have been illustrated by Holmes and Fairon-Demaret (1984, Plate 3, fig. 7) under the name of Anachoropteris sp.2; they are referred as $13 \mathrm{c}$ in our Table 1.

\subsection{The Anachoropteris gillotii-radnicensis group}

As stated above (Section 3.1. and Fig. 1B1-B3) these ferns are characterized by a short and thick foliar xylem with very short arms justifying the erection of the new group based on foliar anatomy. This separation from the "robusta group" is further supported by differences in cauline branching (see Section 3.5).

Anachoropteris gillotii Corsin (1937) type specimen from GrandCroix (Late Pennsylvanian), shows a uniformly thick and slightly recurved xylem strand. Holmes (1979) attributed older Belgian specimens, from Early Pennsylvanian coal balls, to the same species

Plate IV. Other examples of shoots borne on North American Middle Pennsylvanian Anachoropteris rachides. All from Herrin Coal, Illinois. Scale bar = 1 mm.

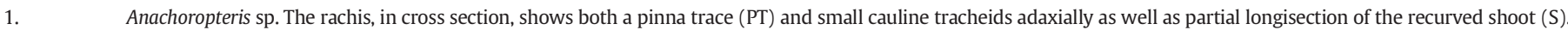
Shawneetown, IL. UI9033DTOP-52.

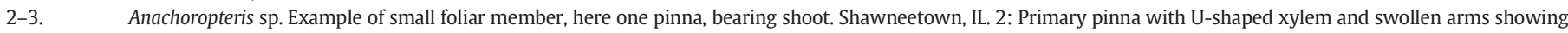
incipient (C) cauline trace. UI8266ABOT-8. 3: the same showing the recurved adaxial shoot (CX) with expanded twice sectioned xylem. UI8266ABOT.

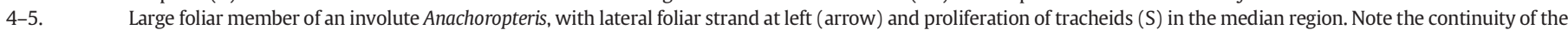
common cortical tissue. 5. Shows the increasing proliferation of cauline tracheids (S) in the median region. Shawneetown, IL. UI2927ITOP-41 and 46.

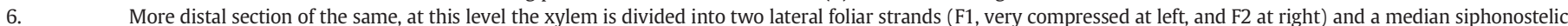
cauline trace (S). The foliar xylem F2 obviously derived from the closing of the inrolled right arm of the initial anachoropterid strand shown in 4. Shawneetown, IL. UI2927ITOP-63.

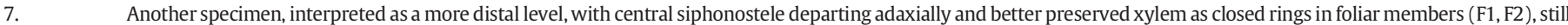
within a common cortex. In foliar xylem F1 there is a "bar" of xylem internal to the closed ring while in F2 the internal bar appears contiguous with the lower region. This represents only a slight change from the xylem anatomy of F2 in 6. Protoxylem groups of small tracheids are on the adaxial face of foliar strands. Nashville, IL. UI Slide 3973, 2524B-7.

Plate V. Other shoots borne on North American Middle Pennsylvanian Anachoropteris rachides. Scale bar = $1 \mathrm{~mm}$. (see on page 42 )

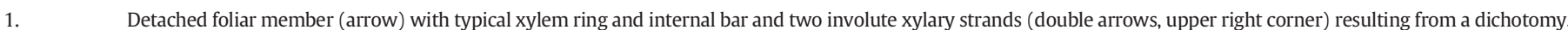
Nashville, IL. UI Slide 4065, 1578BBOT-6.

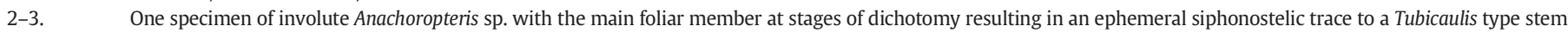
Middle Pennsylvanian, Herrin Coal, Illinois.

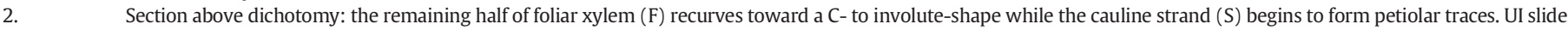
6136-136.

3. A more distal section of the same; the broadened siphonostele shows ground tissue (arrow) similar to that inside the petiolar traces (P). UI slide 6162-75. 
considering that no significant differences can be found with Corsin's figures. Comparison of sections of one French rachis (Plate VIII, 1) and of the Belgian specimen (Plate VIII, 2) actually supports Holmes' assertion. In transverse section the foliar member has a rounded contour, up to $8 \mathrm{~mm}$ diameter in the type specimen; xylem strands range from $0.4 \mathrm{~mm} \times 1 \mathrm{~mm}$ to $0.8 \mathrm{~mm} \times 2 \mathrm{~mm}$. They are slightly concave on the abaxial side, and forming an arc of about one third of a circle. The central apolar region is uniformly 3-5 tracheids thick, while adaxial arms are

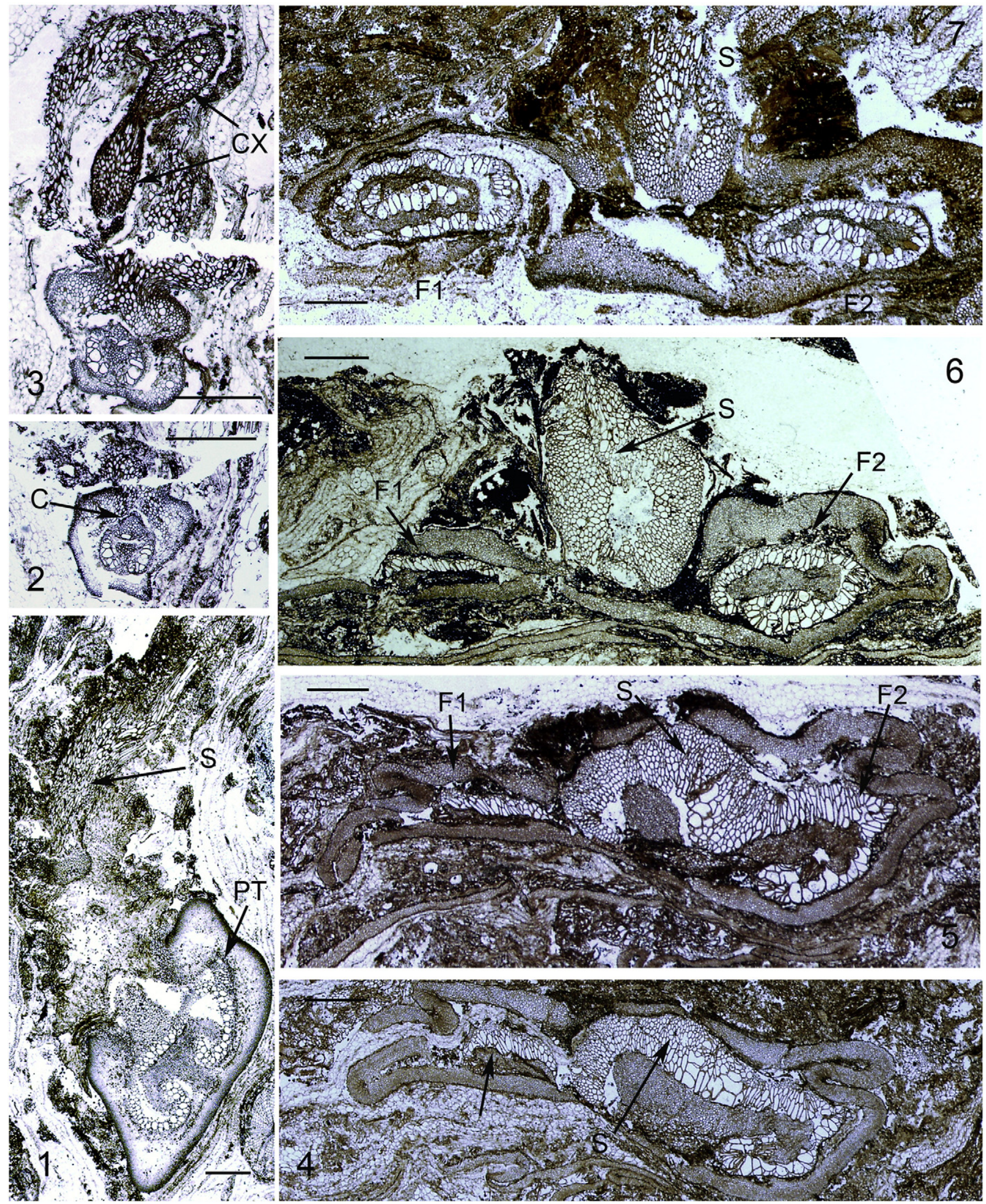



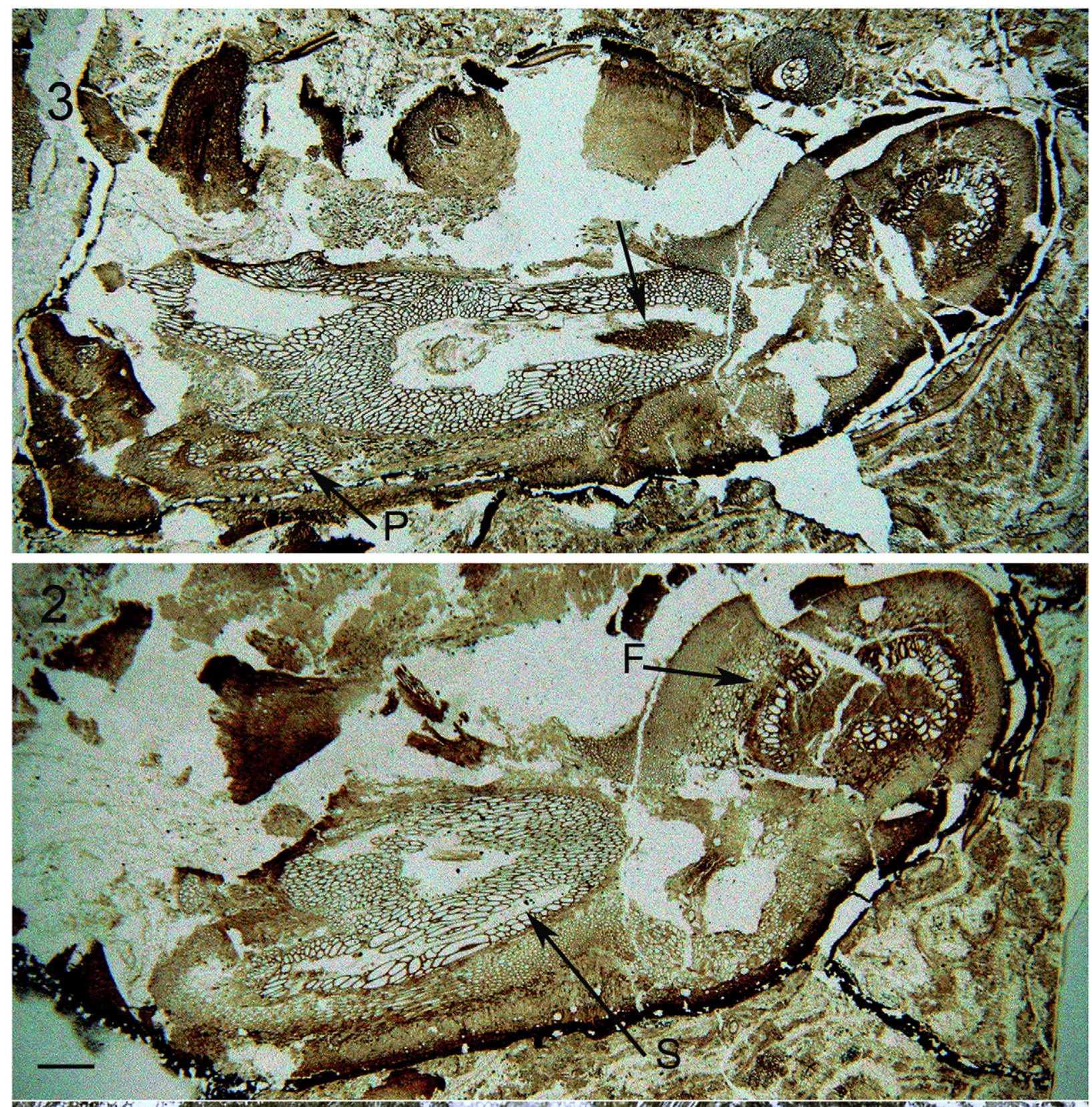

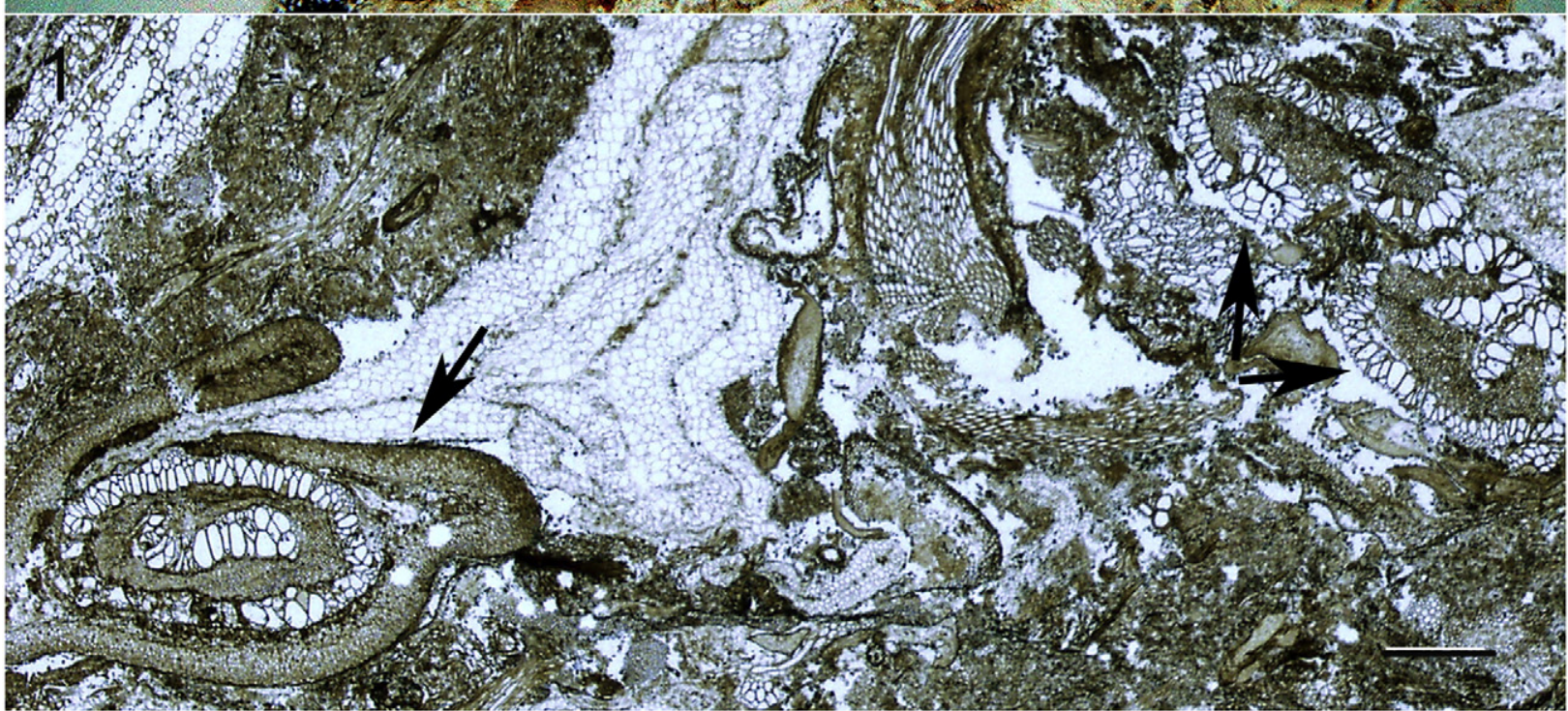




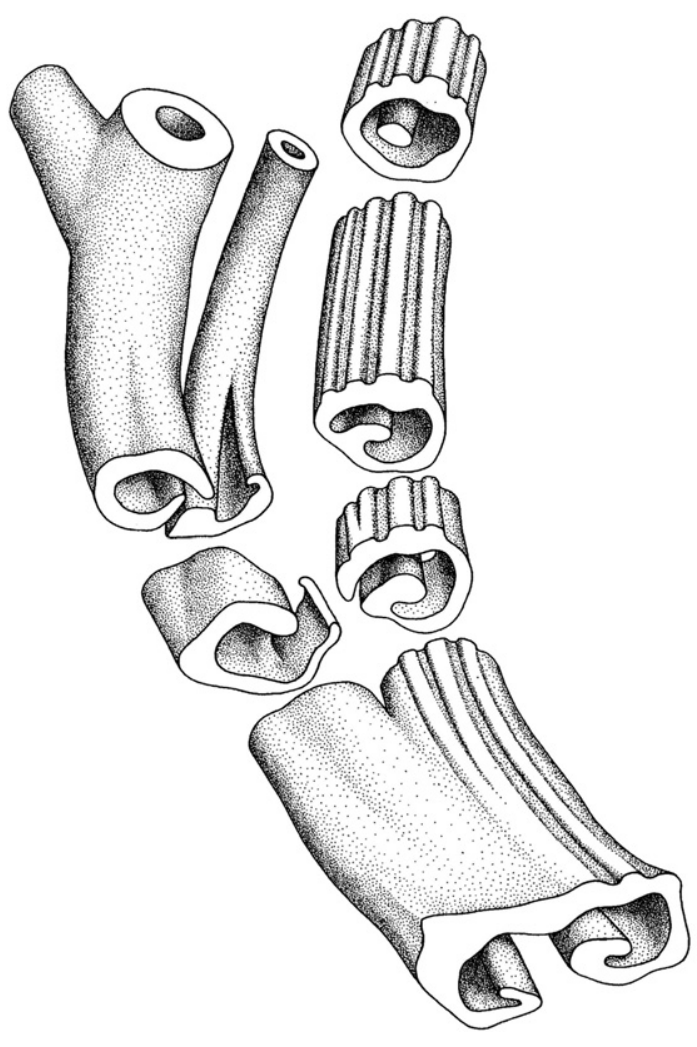

Fig. 4. Composite reconstruction of another type of shoot origin. The lower drawing corresponds to the specimen illustrated on Plate IV, 4-6. It shows the adventious shoot connected to the foliar xylem on the right while the compressed left foliar side (F1, Plate IV, 5) is omitted on the reconstruction. The adventitious shoot has a circular siphonostele, and the first leaf trace also has an $\mathrm{O}$-shaped xylem. On the right side the separating foliar xylem strand progressively incurls to form a closed oval with a small inner xylem bundle.

very short with rounded tips. In both specimens (Plate VIII, 1-2) there is an outer cortex of small elongate cells and an inner cortex composed of wider often isodiametric cells. Very large cells ( $120 \mu \mathrm{m}$ wide and more than $800 \mu \mathrm{m}$ long) are scattered through the inner cortex; they are conspicuous in both transverse (Plate VIII, 1-2) and longitudinal (Plate VIII, 11) sections and also characterize high order foliar members. Such cells are present in the cortex of other species (e.g. Anachoropteris involuta and Anachoropteris williamsonii) and they are often considered to have a secretory function. Foliar branching is documented in the Belgian A. gillotii with pinna base (PI, Plate VIII, 2) showing primary pinna trace and departing basiscopic secondary pinna trace. Distal regions of the frond are unknown.

One must consider that the foliar xylem of Anachoropteris gillotii with very slight abaxial curvature and small arms (B1, B3, Fig. 1) shows the simplest xylem configuration recorded for the genus, together with the poorly known Anachoropteris radnicensis Corda (1845) from the Middle Pennsylvanian (Bolsovian) of Radnice, Czech Republic (B2, Fig. 1); this was confirmed by re-examination of the type material of the last species (Plate VIII, 3, 4, 12). The rachis $(3.8 \times 5 \mathrm{~mm}$ diameter) of $A$. radnicensis has a massive xylem strand $(1.1 \mathrm{~mm} \times 2.2 \mathrm{~mm})$, still less concave abaxially and with shorter arms than A. gillotii. One pinna trace $(0.2 \times 0.3 \mathrm{~mm})$ is shown on Plate VIII, 4 . The cortex is similar to that of $A$. gillotii with scattered large and long cells with black content (arrows, plate VIII, 3 and 12). Another specimen from Grand-Croix (Plate VIII, 5) shows a slender xylem strand $(0.7 \mathrm{~mm} \times 1.8 \mathrm{~mm})$ with very slight curvature, intermediate in characters between $A$. gillotii and A. radnicensis. Considering their overlap in age, the identity of the two species is probable.

Anachoropteris gillotii is of particular interest in a type of trifurcation of a foliar member which gives rise to two foliar organs and a median,

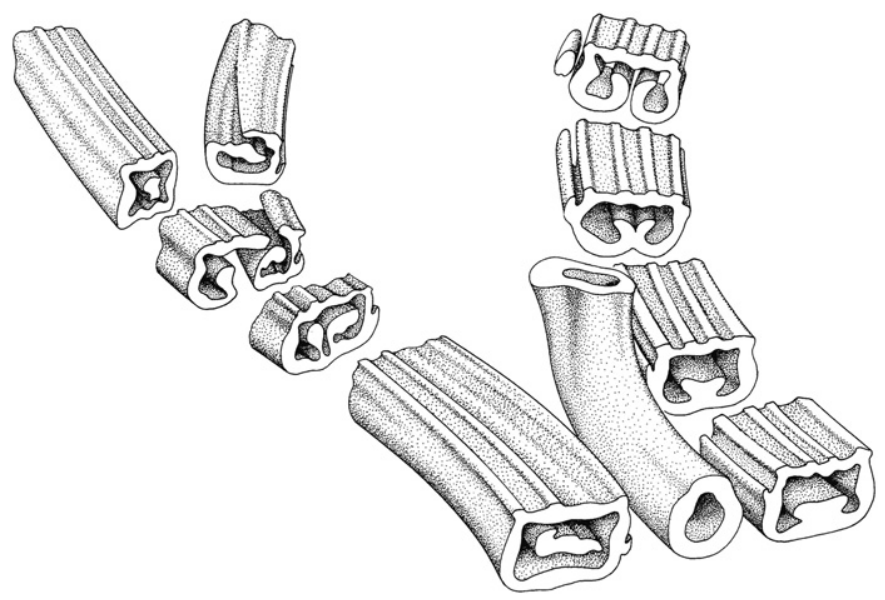

Fig. 5. Xylary reconstruction corresponding to a "trichotomy" cloaked by a common cortex, like that illustrated on Plate IV, 7. The reconstruction shows the median siphonostelic stem forming an incipient leaf trace. Note the rectangular foliar xylem with bar in the mid to lower part of the xylem supply and the adaxial ridges of protoxylem. The foliar xylem to the right shows a progressive conversion to an involute pattern with pinna trace departure. On the left side the foliar xylem undergoes an unequal dichotomy with each member resuming a closed xylary configuration.

slightly adaxial cauline strand which shows the initiation of a petiole trace, as described and nicely reconstructed by Holmes (1979, Fig. 1). This was observed in two Belgian specimens; at the most proximal extremity the foliar xylem $(1 \mathrm{~mm} \times 2 \mathrm{~mm})$ shows a slight abaxial curvature and three protoxylem strands (arrows, Plate VIII, 6). Higher up, the right-hand protoxylem divides in two, then one third of the foliar xylem mass departs to the right as an oval shaped strand (TF1, Plate VIII, 7) with two adaxial protoxylem groups. At this stage the larger strand, tF2, is curved on both sides with two adaxial protoxylem poles; both strands are bound by the same cortex with typical scattered large cells. A little higher, a buildup of small tracheids (TS, Plate VIII, 8) occurs around the right-hand protoxylem of tF2 and several roots are seen to depart from this region. Finally the addition of tracheids continues to form the stem stele which separates (TS, Plate VIII, 9). At this level the foliar member at right (F1) is free while the stem stele and left-hand foliar member strand TF2 are bound in a common cortex. At higher levels the three organs become free; the stem stele is circular with a diameter of $0.8 \mathrm{~mm}$ and one centrarch proxylem strand. It then prepares to emit a bar-shaped petiole trace (PT, Plate VIII, 10). The sides of the "bar" remain attached while the center is separated by the formation of a lacuna (L, Plate VIII, 10) interpreted by Holmes (1979) as a probable decurrent parenchymatous strip adaxial to petiole strand. Information is unfortunately missing on more distal regions of these specimens.

This type of foliar to cauline branching is a distinctive morphological feature that is characteristic of Anachoropteris gillotii, where one rachis divides unequally to form two new foliar members, the largest of which produces a stem; this is without an exact parallel with the situation described above in Anachoropteris williamsonii (Section 3.3) and Middle Pennsylvanian American specimens (Section 3.2.3) where dichotomy of the rachis occurs simultaneously with the production of a central adaxial stem and two foliar organs with a circular xylem strand distinct from the involute parent rachis. In A. gillotii the xylem strands of the two resulting rachides reproduce the initial configuration.

\subsection{The Anachoropteris robusta group}

This group was established by Corsin (1937) for species characterized by a uniformly thick xylem strand with more or less recurved but not inrolled arms, including Anachoropteris robusta, Anachoropteris pautetii, Anachoropteris circularis, Anachoropteris gillotii and Anachoropteris 
radnicensis. In the present work the last two species have been treated as a separate group (Section 3.4) even if they are considered as more closely related to the Anachoropteris of the robusta group than to the involute forms.

\subsubsection{The Anachoropteris robusta group}

The oldest member of this group, and the oldest known Anachoropteris (Fig. 1A), was illustrated by Remy and Remy (1977, fig. 49) under the name of Anachoropteris sp. from coal balls of the Namurian C of EssenWerden, Germany. According to their figure, this rachis was about $6 \times$ $3 \mathrm{~mm}$ in diameter; its broad xylem strand ( $3.8 \mathrm{~mm} \times 1.2 \mathrm{~mm}$ ) was of uniform thickness, with a long median "apolar" region and rather short arms with a sharp tip. These characters allow distinguishing this Anachoropteris from those of the gillotii-radnicensis group where the xylem strands possess a shorter median region and very small arms with round tips (compare Fig. 1A with Fig. 1B1-B3). However, this Anachoropteris may be considered as basal to the "robusta group" (Fig. 1C1-C7) where the xylem strands show variously long arms.

The type of Anachoropteris robusta Corsin (1937) from the Late Pennsylvanian of Grand-Croix (Fig. 1C4) shows a C-shaped xylem strand (up to $4.7 \times 2.7 \mathrm{~mm}$ ) with recurved and tapered (horn-like) arms, and protoxylem strands protruding adaxially as crescentic cusps (arrows, Plate IX, 1). The departing pinna trace is initially oval-shaped. Corsin (1937) distinguished Anachoropteris pautetii (Fig. 1C5) for smaller rachides with proportionally longer xylem arms. Holmes and Fairon-Demaret (1984, Plate 3, 5) illustrated, as Anachoropteris sp.1 (Fig. 1C1), a rachis from Bouxharmont which may be attributed to A. robusta but showing proportionally longer xylem arms (Plate IX, 3). Additional specimens, with xylem strand and cortex more similar to those of $A$. robusta, suggest the occurrence of this species already in the Early Pennsylvanian. Furthermore we found evidence of associated small rachides (Plate IX, 2) that we interpret as free pinnae, or $2 \mathrm{~d}$ and $3 \mathrm{~d}$ order rachides. The primary pinna or second order rachis (PP) is $1.6 \times 1 \mathrm{~mm}$ broad with a small bent xylem strand and departing pinna trace; the free tertiary rachis (SP) is about $0.5 \mathrm{~mm}$ in diameter. However, we did not find evidence of pinnules. The species A. robusta is now also recorded from the Middle Pennsylvanian (Fig. 1C2-3; Plate I, 3 and Plate IX, 4-5) and the Late Pennsylvanian (Fig. 1C6; Plate IX, 6) of the U.S.A. The American rachides show some variability in the length of the xylem arms and of the median "apolar" region but in all cases, as in A. robusta, the xylem strand is uniformly thick and the similar cortical tissues include scattered large cells in the outer cortex; when preserved, the central cortex (inside the xylem concavity) shows thickened cells. Massive oval to circular lateral traces have been observed in the American rachides (Plate I, 3; Plate IX, 5-6); they are interpreted as probable pinna traces.

Anachoropteris circularis was founded by Corsin (1937) on a single specimen, about 6 mm diameter, from Early Permian cherts of Autun. Holmes (1981b) studied the variability of this species in rachides ranging from 2 to $9 \mathrm{~mm}$ diameter with a circular to oval contour (Plate IX, 7-11), a xylem strand 1 to $4.5 \mathrm{~mm}$ wide, and homogeneous ground cortex extending inside the xylem concavity even in small rachides (Plate IX, 7-10). Incipient lateral oval traces (LT, Pl. IX, 7) are similar to pinna traces in Anachoropteris robusta. One large rachis shows a rounded primary pinna base (Plate IX, 11) with a trapezoidal pinna trace (PPT) showing two adaxial protoxylem strands; in addition, one secondary pinna (SP) is seen arching across the adaxial face of the rachis while the trace for another secondary pinna (SPT) is departing to the right. The recurved secondary pinna rachis is rather thick but evidence of further branching or of laminate pinnules is lacking. The morphology of this arching pinna is similar to that known in several involute anachoropterids (e.g. Plate III, 3 and Plate VI, 1) and designated as "aphlebiae" by Corsin (1937).

Comparison of two large-sized specimens of Anachoropteris circularis and Anachoropteris robusta supports their taxonomic distinction: the xylem strand has long arms with rounded and eventually slightly enlarged tips in A. circularis (Plate IX, 10) instead of shorter tapered arms and proportionally longer median region in A. robusta (Plate IX, 1). This is expressed by differences in the ratios $\mathrm{a}=$ xylem strand radial width/ tangential width and $\mathrm{b}=$ length of median apolar region/tangential width, with always $\mathrm{a}>\mathrm{b}$ in $A$. circularis while it is about $\mathrm{a}=\mathrm{b}$ in A. robusta. However, in some rachides from Autun the xylem arms are proportionally shorter and with sharper tips (Plate IX, 11) and these are similar to Anachoropteris pautetii. Actually, some Belgian (Plate IX, 3 ) and American (Plate IX, 4) rachides attributed to A. robusta show a ratio $\mathrm{a}>\mathrm{b}$ similar to that in $A$. circularis but none possessed enlarged and rounded tips. In contrast, the oldest Anachoropteris sp. from Germany (Fig. 1A) shows very low values with $\mathrm{a}<\mathrm{b}$. It is not our purpose in this paper to solve the taxonomic problem of probable synonymies, and we consider the species of the "robusta group" (Fig. 1 C1-7) as representing an evolutionary continuum from the Early Pennsylvanian to the Early Permian.

\subsubsection{Lateral shoots in Anachoropteris of the "robusta group"}

The first example of such foliar to cauline branching was described by Holmes (1981b) in a rachis, from the Late Pennsylvanian of GrandCroix, illustrated here on Plate IX, 13. This rachis (6 mm broad with a

\footnotetext{
Plate VI. Foliar members of the Early Pennsylvanian Anachoropteris williamsonii from European coal balls of Belgium and England. Scale bars $=1 \mathrm{~mm}$, except in 4 and $5=0.5$ mm.

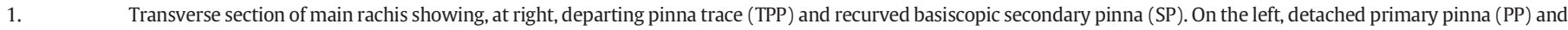
acroscopic secondary pinna (SP). Bouxharmont, Belgium. ULG BX 220 EB12.

Same rachis, more proximal section showing detail of the sub-opposite pinna traces (arrows) corresponding to the two pinnae shown in 1 . ULG BX220 FB03. Anachoropteris williamsonii rachis from British coal ball showing an initial stage in one pinna trace formation (arrow). Burnley, Lancashire. UM2 B141 A 01. Detail of detached primary (PP) and secondary (SP) pinna rachides. Note the U-shaped xylem strand of R2 and the small circular strand of R3. ULG BX 220 EB10. Detail of pinna base with the broad U-shaped pinna xylem and the precocious emission of the small trace (arrow) to the first basiscopic secondary pinna (shown free and recurved in 1). ULG BX220 FT01.

Transverse section of one foliar structure resulting from the trifurcation of a rachis (= detail of F2, Plate VII, 3). Note the circular xylem strand with two groups of small tracheids (arrows) and central small cells similar to those inside inrolled xylem arms of 2. One root (R) is departing at left. ULG BX595 EeB01.
}

Plate VII. Shoots resulting from trifurcation of the Early Pennsylvanian Anachoropteris williamsonii. All scale bars $=1 \mathrm{~mm}$. (see on page 46 )

1-3: $\quad$ Trifurcation of a probable Anachoropteris williamsonii rachis resulting in a median adaxial shoot, Bouxharmont, Belgium.

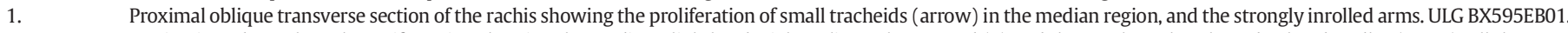

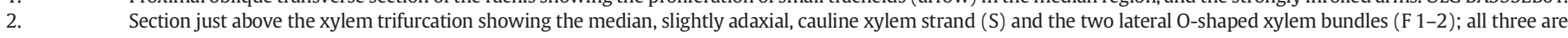
still within a common cortex. ULG BX595EB07.

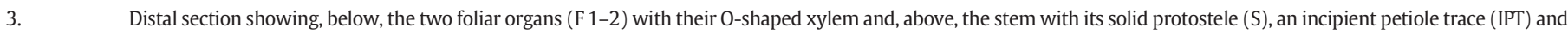
free petiole traces (PT). The outer stem cortex is missing. ULG BX595EeB01.

4-6: $\quad$ Similar epiphyllous shoot from Union Seam, England.

4. $\quad$ Section above the trifurcation showing the median recurved xylem of the shoot (S) and the two O-shaped xylem strands of foliar structure (F 1-2). UM2 B36TB 31.

5. $\quad$ Section showing the stem xylem twice sectioned (S); the foliar structures (F 1-2) are less well preserved. UM2 B36TB 55.

6. Distal section, detail of the stem protostele with evidence of parenchyma cells and two petiole traces (PT). UM2 B36 ET01.

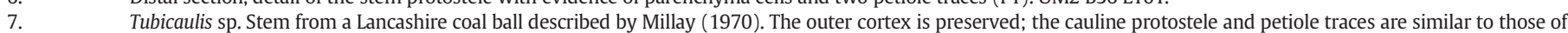
shoots illustrated in 3 and 6 . Note the free petiole (P) with a slightly recurved xylem. UM2 LAN2700EB02. 
xylem strand $3.2 \times 1.9 \mathrm{~mm}$ ) was attributed with some reservations to Anachoropteris robusta because its xylem strand was of irregular thickness, as in Anachoropteris pautetii, with the arms thicker than the median region and less recurved than those of $A$. robusta. Considering that this rachis is twice larger than the type specimen of A. pautetii, this difference may be of taxonomic value and not an ontogenetical one. However, the main interest of this specimen concerns the occurrence of a departing trace (ST, Plate IX, 13) in the form of a cylindrical protostele,
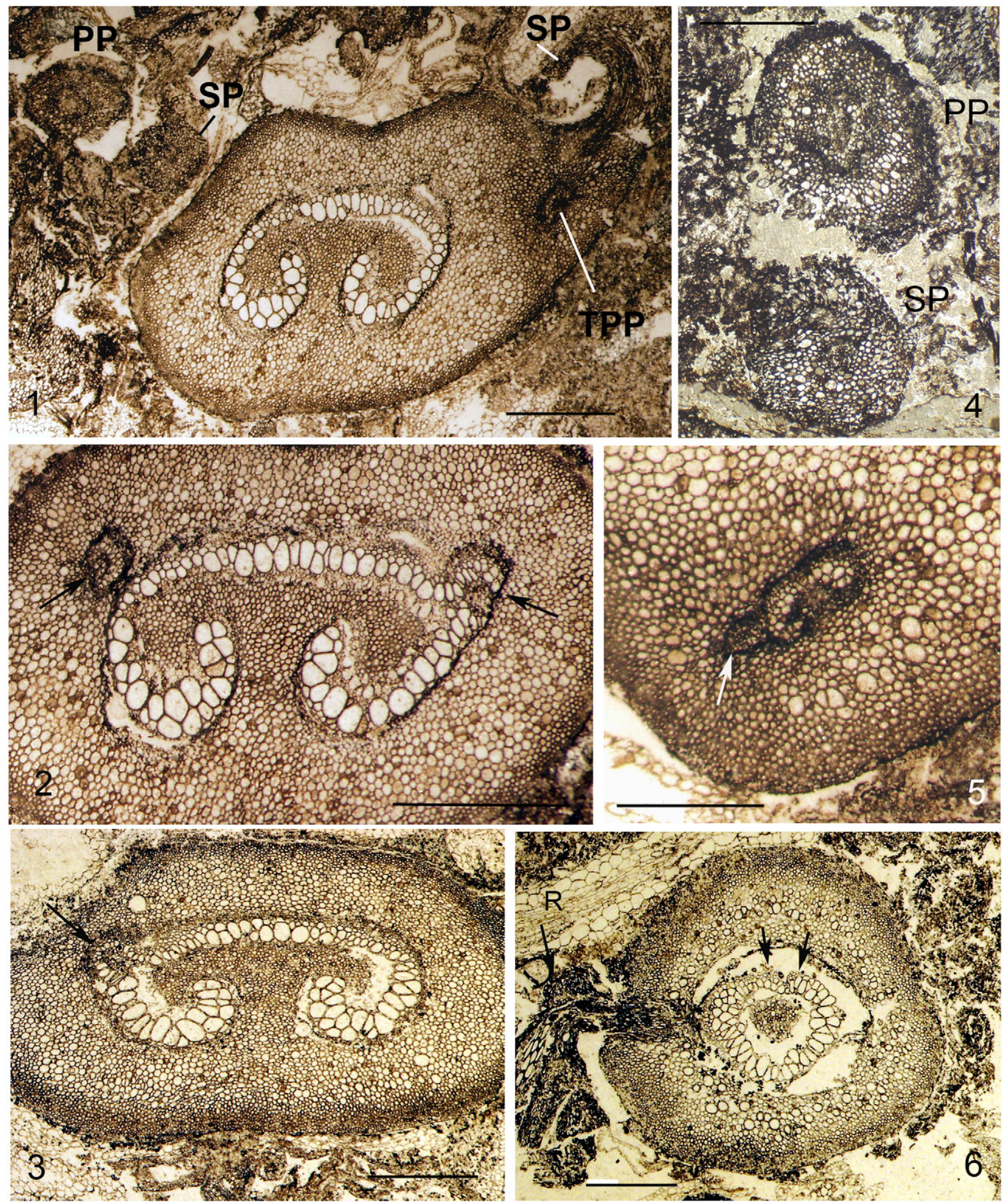


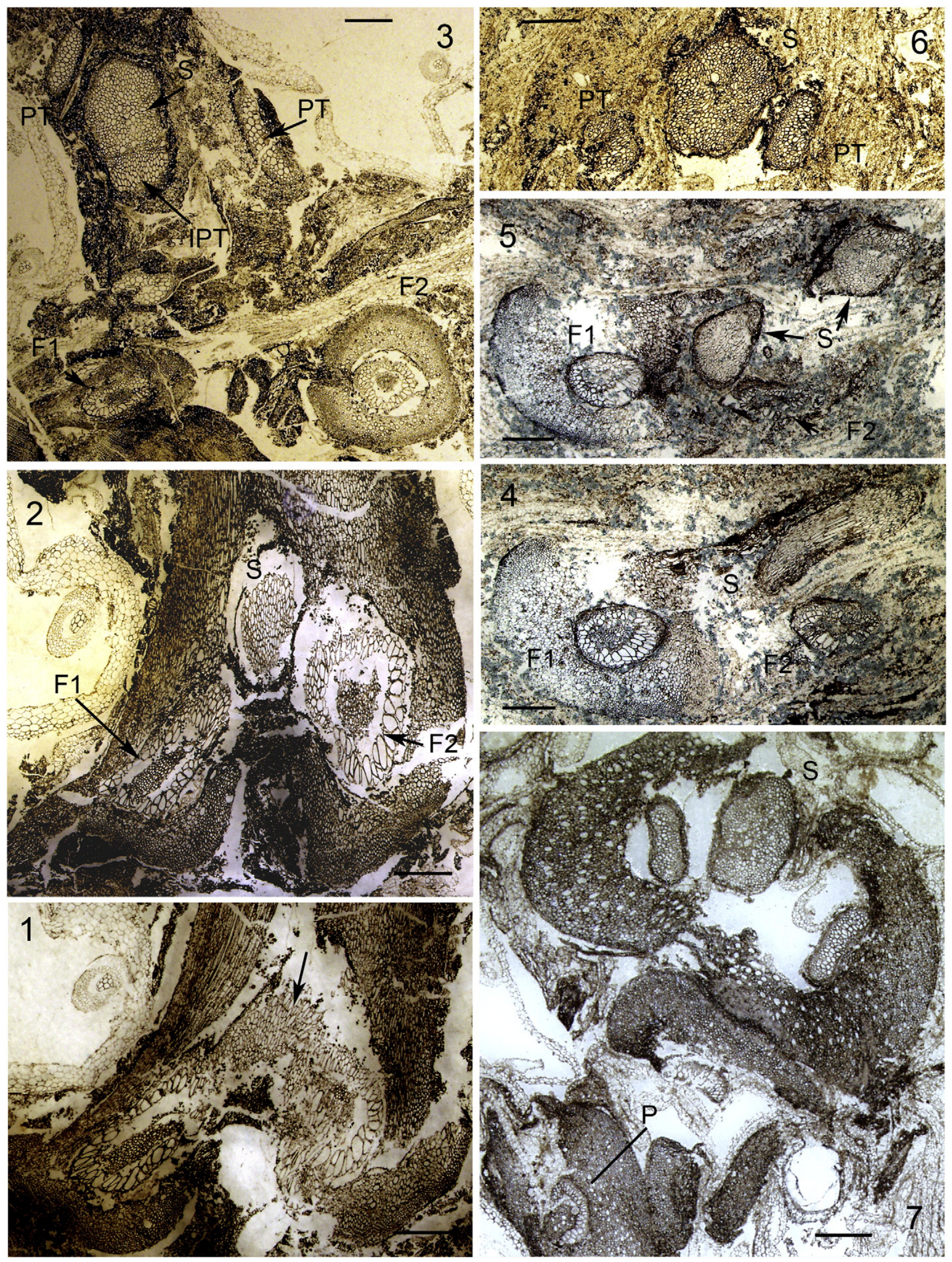

Plate VII (see caption on page 44). 


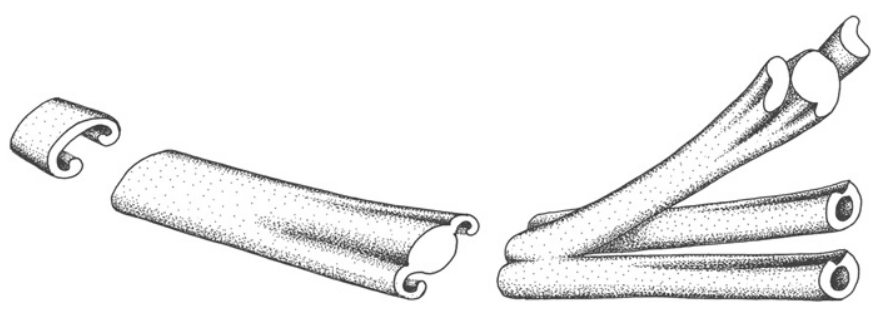

Fig. 6. Simplified reconstruction of the shoot origin in Anachoropteris williamsonii from the trifurcation of a large foliar member, resulting in a median protostelic stem and two lateral foliar members with circular xylem. Based on the Belgian specimen illustrated on Plate VII, $1-3$.

about $1 \mathrm{~mm}$ in diameter, composed of small tracheids of rather uniform size. The most proximal section was above the level of trace departure from the rachis xylem but serial peel sections show the trace departing to the left, enlarging and detaching one root trace before it was broken. The cauline nature of this trace is evident.

Another example of foliar to cauline branching is documented on a rachis of the Anachoropteris robusta type from the Early Permian of Autun; this occurs in two consecutive thin sections of Renault's collection. On the basal section the rachis is circular in transverse section with a xylem strand less than $3 \mathrm{~mm}$ broad, with one incipient oval lateral trace similar to the example illustrated on Plate IX, 7. However, on the next section (Plate IX, 12) the rachis shows a small shoot longitudinally sectioned and attached on the same left flank. This small cauline structure is morphologically a small bud $(6 \mathrm{~mm}$ long and $2.5 \mathrm{~mm}$ in diameter) departing laterally, and then perpendicularly with regard to the parent rachis. The central cauline strand (ST, Plate IX, 12) is sectioned longitudinally and shows the emission of several traces to successive roots $(R)$ in the most proximal region of this small shoot. The dome-like apical region of the bud is covered with hairs. This type of lateral shoot appears similar to the previous one illustrated on Plate IX, 13.

Several specimens of Anachoropteris circularis from the Early Permian of Autun correspond to rachides of very different sizes (Plate IX, 7-10) bearing lateral shoots. In the first example (Plate IX, 7) the lateral trace was first interpreted as an incipient pinna trace; however, serial sections reveal that higher up this trace became circular and departed obliquely. A similar situation is observed in another rachis (Plate IX, 8) showing an intermediate stage with a bipartite trace. Higher up, the same rachis shows the enlarged outgoing trace; its inner part (PT, Plate IX, 9) is interpreted as an oval pinna trace still attached to the outer cauline part (ST). The same type of branching is observed in one of the largest A. circularis rachis illustrated on Plate IX, 10. In this case also, the voluminous departing trace is interpreted as a common trace to a pinna and a shoot borne laterally. Roots are observed departing very proximally from the cauline strand through the rachis cortex. In all these examples the shoot was broken near its level of attachment.

In conclusion, one must emphasize that the Anachoropteris of the "robusta group" are characterized by the production of lateral shoots, similarly to those of some Anachoropteris of the "involuta group" (see Section 3.2.2); this pattern is distinct from the foliar to cauline branching known in the related "Anachoropteris gillotii group" and it is an additional argument to separate the two groups.

\subsection{Anachoropteris clavata}

Anachoropteris clavata Graham (1935) was founded on small-sized rachides (averaging $2.5 \mathrm{~mm}$ in diameter) with a U-shaped xylem strand showing typically expanded club-like abaxial arms, very distinctive in comparison to other species (Plate I, 6 and Fig. 1G). The type material of this species was from the Late Pennsylvanian of Calhoun Coal, Illinois. From additional specimens of the same origin, Delevoryas and Morgan (1954) provided the first evidence of a stem of Anachoropteris and the first report of shoots on foliar members in anachoropterid ferns. In this important study, the authors demonstrated that lateral traces, arising from a rachis, supply either one pinna or an independent axis which was designated as a stem since it possesses a radial symmetry and because petiole-like structures and roots arise from it. The rachis from which the stem originates was called a "primary petiole" to differentiate it from the "secondary petioles" which arise from the stem. The authors noted the obconical construction of the stem but they indicated that regular phyllotaxy was not detected for the secondary petioles. Finally, they suggested that the main rachides/primary petioles may represent scrambling stolon-like structures on which shoots were borne.

Recently Tomescu et al. $(2006,2008)$ reconstructed the whole plant, Kaplanopteris clavata, on the basis of vegetative and fertile frond fragments and rhizomes. Characteristic anatomy conforming to the morphospecies Anachoropteris clavata allowed for integration of previously described material from the Late Pennsylvanian of Illinois with new material from Duquesne Coal, Ohio which was the object of preliminary studies by Rothwell (1987) and Trivett and Rothwell (1988). In agreement with specimens studied by Delevoryas and Morgan (1954), the authors described the production of an epiphyllous stem (called "rhizome") originating as an elliptical vascular bundle that diverges laterally along the frond rachis "at positions of primary pinnae". The increase in diameter and transition of the cauline strand into a circular protostele was documented, as well as the divergence of the first "stipe" bundle (= "secondary petiole" of Delevoryas and Morgan, 1954). Two petioles were observed diverging from the stem preserved for about $10 \mathrm{~mm}$ in length while Delevoryas and Morgan observed up to four fronds. The authors also described the overall morphology of tripinnately dissected fronds with laminate pinnules, as well as latent croziers that replace primary pinnae. Finally, the authors reconstructed $K$. clavata as a primarily vining or climbing plant consisting principally of "indeterminate vining fronds produced by scanty, small erect rhizomes" (Tomescu et al., 2006) and combining two types of reiterative growth (Tomescu et al., 2008).

One rachis of Anachoropteris clavata bearing a stem, from the Late Pennsylvanian of Berryville (Calhoun Coal, Illinois) is illustrated on Plate X. The most proximal section (Plate X, 1) shows, within the same cortex, the U-shaped xylem strand of the rachis and a smaller lateral trace (LT) at right. In the present case, this lateral is interpreted as a "common trace" consisting of the C-shaped strand of a primary pinna trace (PPT) with the addition of some cauline tracheids (CT), and of one small departing secondary pinna trace (SPT) as shown on the enlargement (Plate X, 4). The series of more than one hundred sections reveals that differentiation was first in the pinna trace, then adventitious cauline tracheids. The addition of cauline tracheids continues upwards, resulting in a typically circular protostele as broad as the adjacent pinna trace (Plate X, 2 and 5). In the interval one small trace, detached from the pinna trace from the left side (SPT2, Plate X, 5), is interpreted as the second secondary pinna trace. At this level, the lateral organ containing the bipartite common trace is free cortically (Plate X, 2) but it is only higher up that the shoot and the pinna rachis will separate (Plate X, 3). Root traces have been observed departing from the cauline trace between the levels of figs. 2 and 3 of Plate X. Preservation does not allow observing any petiole borne on the shoot. We interpret this specimen of A. clavata as bearing a shoot at the base of a pinna which, in turn, bears proximally two secondary pinnae. This type of foliar to cauline branching is similar to that described in A. involuta (Plate II, 6) where a cauline shoot is attached to a pinna trace. If this interpretation is correct, A. clavata would possess a variability in the position of shoot divergence, ranging from the base of a pinna to a direct lateral divergence from the rachis, as described by Delevoryas and Morgan (1954) and Tomescu et al. (2006).

\subsection{Fertile structures}

The first report of supposed fertile parts of ferns having Anachoropteris-type anatomy was by Kubart (1916) who attributed to 
Anachoropteris pulchra some foliar structures bearing synangia described under the name of Chorionopteris gleichenioides by Corda (1845). As stated above (Section 3.2.1) the re-investigation of the original Corda's material did not allow us to recognize any organic connection with A. pulchra and it is suggested that Chorionopteris actually represents marattialean fertile parts belonging to one of the associated Psaronius.

\subsubsection{The Sermayaceae, from the American Late Pennsylvanian}

Sermaya Eggert and Delevoryas (1967) was established for a fertile frond with Anachoropteris anatomy from the Calhoun Coal, Berryville, Illinois. The type specimen consists of three orders of frond axes or rachides; the "basal axes", 6 to $7 \mathrm{~mm}$ wide in cross section, possess a C-shaped xylem strand (about $2 \mathrm{~mm}$ wide) with recurved but apparently not inrolled arms (Fig. 7A1). We consider that they are rather similar to an Anachoropteris of the "robusta group"; as in this species, the departing trace to a higher order rachis is elliptical, then it becomes abaxially curved in the free secondary rachis (Fig. 7A2) or "primary lateral axes" of Eggert and Delevoryas. The last bear, alternately and closely spaced, tertiary rachides in which the small xylem strand still exhibits a slight abaxial curvature (Fig. 7A3); they correspond to ultimate rachides bearing alternate pinnules with lamina extending between bases of adjacent pinnules.

The pinnules are lobed, more than $4 \mathrm{~mm}$ long, and of the Sphenopteris type with a definite midvein and sub-opposite lateral veins dichotomously branched (Fig. 7A4). The pinnules are very thin with not clearly differentiated mesophyll. Radial sori, consisting of about 4 sporangia, are distributed on the abaxial surface of the pinnules but the attachment of the sporangia was difficult to determine. Sporangia are small (about $0.35 \mathrm{~mm}$ in diameter), sessile with a horizontal-oblique annulus consisting of two interdigitating rows of thick-walled cells on the distal face (Fig. 7A5). The sporangial wall, one cell in thickness, opened along a longitudinal dehiscence zone. Spores are trilete, subtriangular and may be referred to the sporae dispersae genus Leiotriletes (Naumova) Potonié and Kremp.

\footnotetext{
Plate VIII. Anachoropteris of the "gillotii-radnicensis group". Unlabelled arrows pointing to the two main protoxylem groups. All scale bars $=1$ mm.
}

Anachoropteris gillotii from the Late Pennsylvanian of Grand-Croix (= B3, 1), transverse section of rachis with circular contour, broad cortex with scattered large cells, and recurved xylem strand with the two persistent adaxial protoxylem strands (white arrows) and incipient pinna trace (IPT). UM2 GC560A.

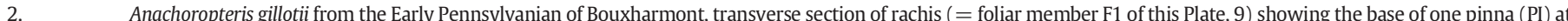
left with pinna trace. Note large cells scattered in the inner cortex including the pinna base. The foliar xylem strand is slightly recurved with short arms and rounded tips. ULG BX695AB96.

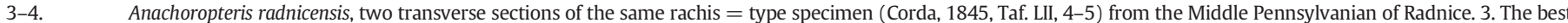
preserved section (=B2, Fig. 1) showing the cortex with scattered wide cells (black arrows) and the xylem strand that is comparatively broader and less recurved than in A. gillotii. 4. Another section showing a departing pinna trace (pt). NMP, Corda Coll. E216 AB and AT.

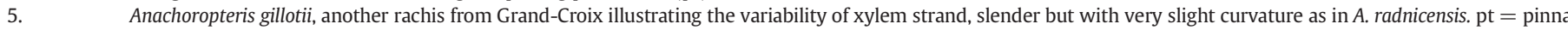
trace. UM2 GC510 AT05.

6-10. Anachoropteris gillotii from Bouxharmont, ascending transverse sections through specimen showing foliar borne stem as reconstructed by Holmes (1979).

6. Massive xylem strand, in most proximal region; the third (non-arrowed) protoxylem strand, at right, corresponds to incipient TF1. ULG BX92A2A1T18.

7. Separation of xylem strands TF1 and TF2 each with two protoxylem strands and pinna trace (tpi) at right. ULG BX695A1GB07.

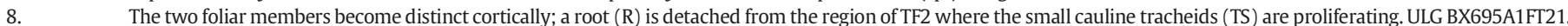

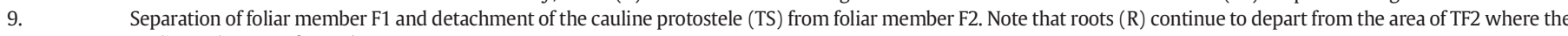
cauline xylem was formed. ULG BX695A1EB109.

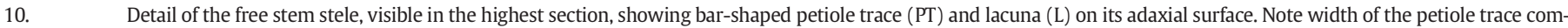
pared with stem. ULG BX695A1DT03.

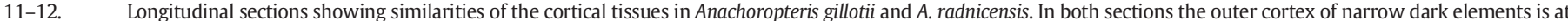
left; the inner parenchymatous cortex contains scattered elongated (?canal-like) elements with dark contents (arrows). 11. A. gillotii. ULg BX695 DLF1/11. 12. A. radnicensis. NMP, Corda coll. E216 BL.

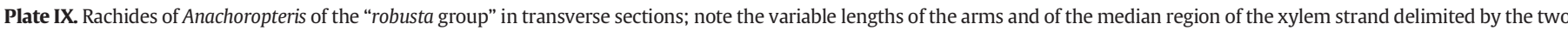
persistent protoxylem strands (arrows). Scale bars $=1 \mathrm{~mm}$. (see on page 50 )

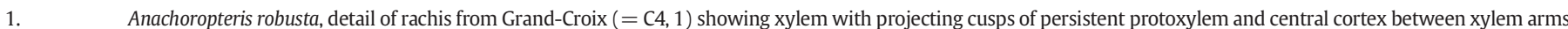
UM2 GC1230AB01.

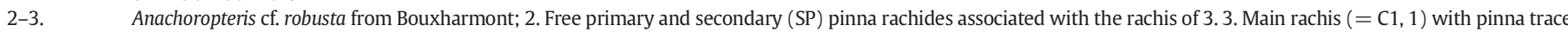
(PT). ULg BX780AT01.

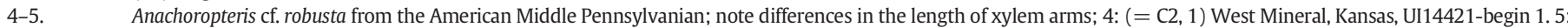
(= C3, 1) Shawneetown, IL, Ul3123BBot22.

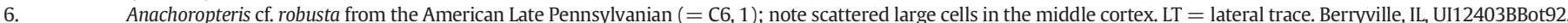
7-11. Anachoropteris circularis of different diameters, from the Early Permian of Autun.

7: $\quad$ Note the short median region and incipient lateral trace (LT) which higher results into a cauline trace. MHNA ROC SN12.

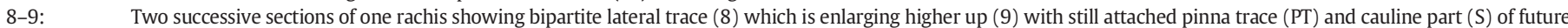
shoot. MNHNP 240 and 242 ROC11.

10. Very large rachis with departing cauline trace (CT). MNHNP 465ROC21.

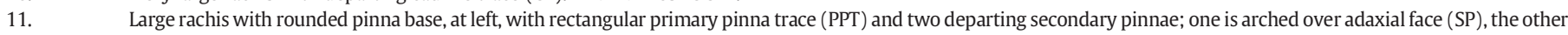
(SPT) is broken. MNHNP1325ROC.

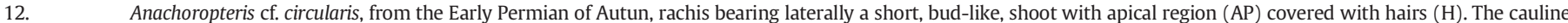
strand (ST) is sectioned longitudinally and emits several roots (R). MNHNP 1066REN47.

13. Anachoropteris cf. pautetii, from the Late Pennsylvanian of Grand-Croix, rachis with cylindrical cauline trace (ST) departing at left. UM2 GC508AT05.

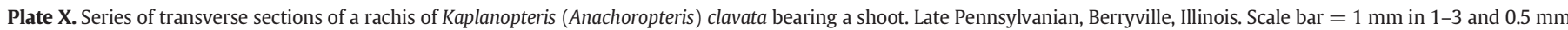
in $4-5$. (see on page 51 )

1. The U-shaped xylem strand of the parent rachis and the lateral trace (LT) are in a common cortex; detail in 4. UI1168CTOP143.

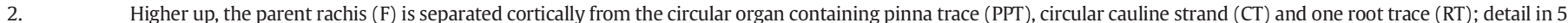
UI168CTOP07.

3. More distal section, near the level of cortical separation of the shoot (S) borne on pinna (PP). Note the departing secondary pinna trace (SPT). UI1168BBOT06.

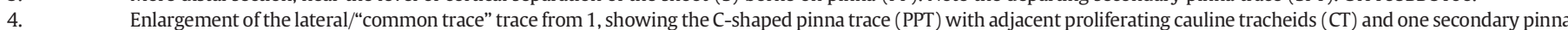
trace (SPT). UI1168CTOP143.

5. The same higher up, showing pinna trace (PPT) with cauline protostele (CT) of greatly increased diameter, and another secondary pinna trace (SPT2). UI1168CTOP07. 
Doneggia complura Rothwell (1978) from the Duquesne Coal, Ohio, is another Late Pennsylvanian member of the Sermayaceae. The original material consisted of 3 orders of leaf branching, including laminar pinnules. Larger frond axes (about $4 \mathrm{~mm}$ wide) with abaxially involute xylem strand are assignable to the morphogenus Anachoropteris (Fig. 7B1); however, they are associated but not found attached
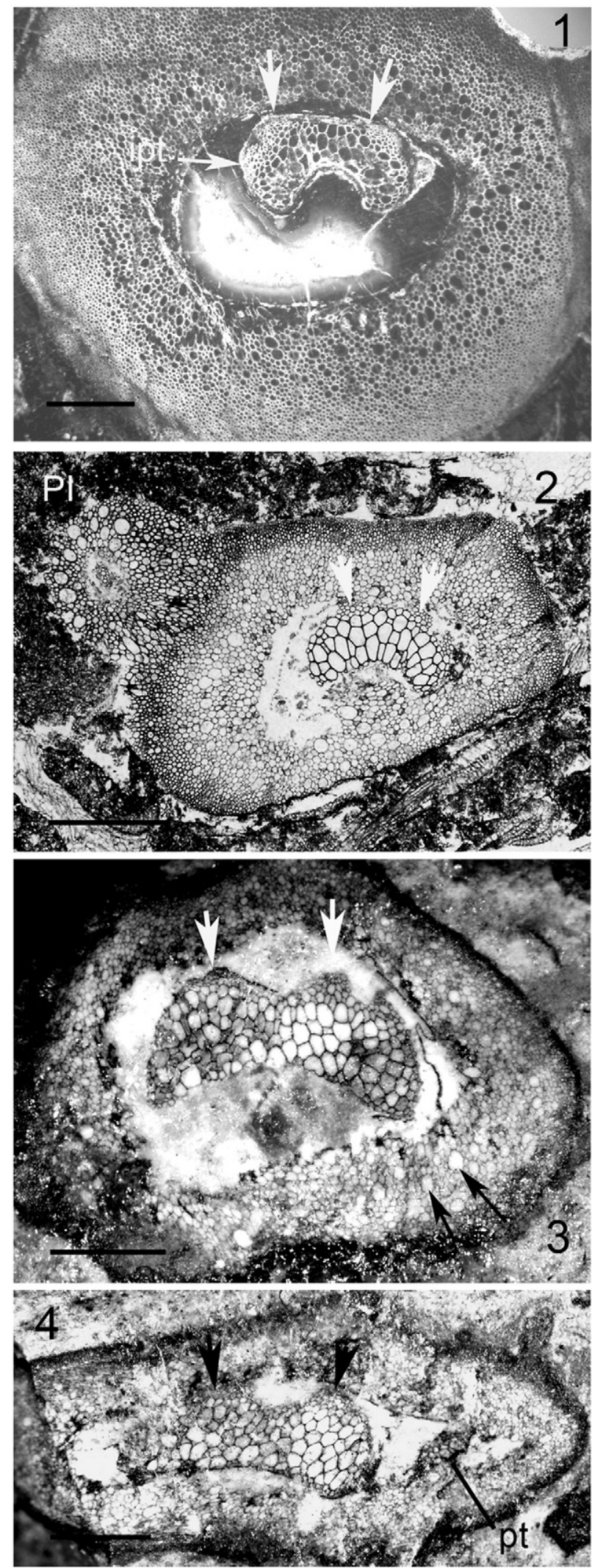
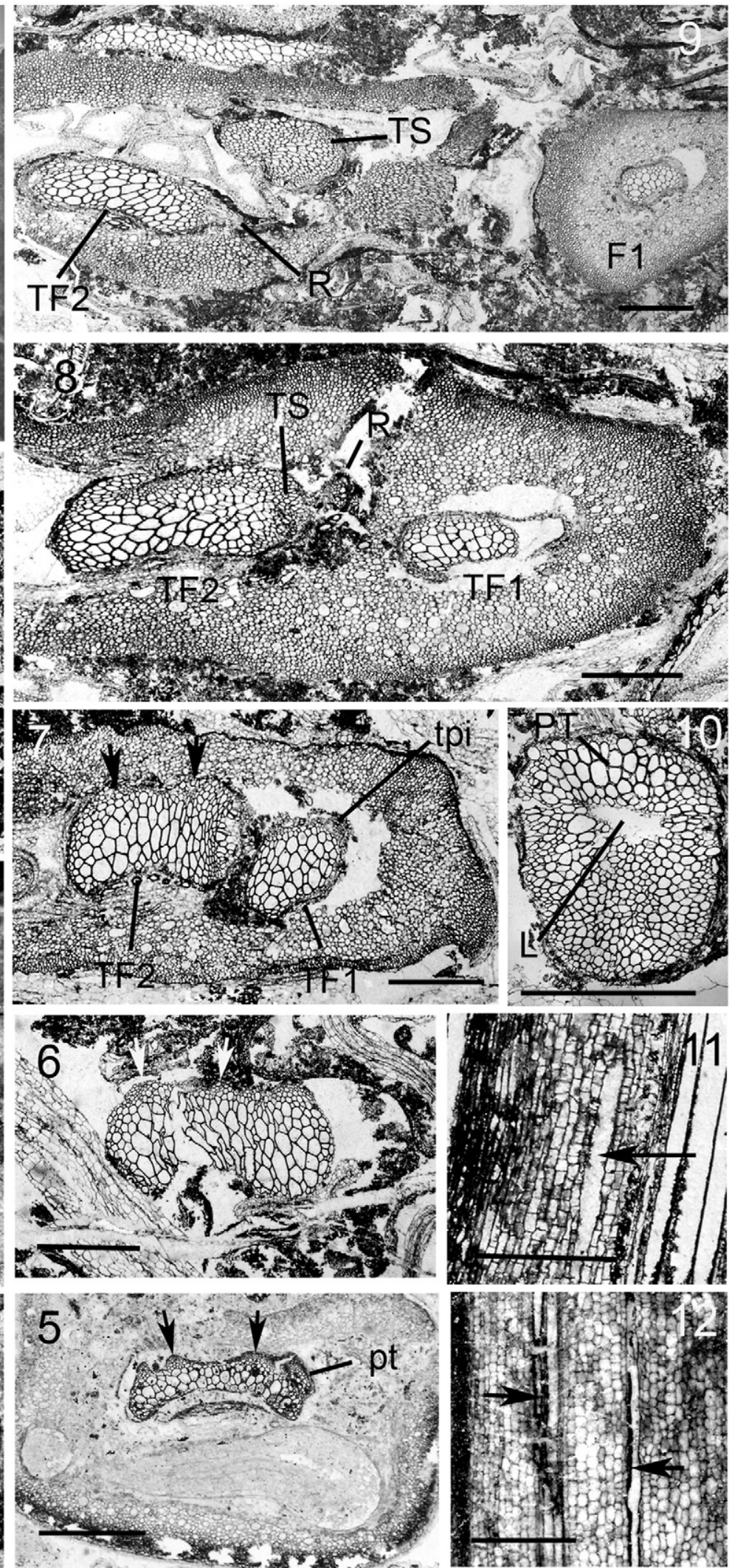

Plate VIII. 
to Doneggia material. The most proximal rachides in connection (= penultimate pinnae) are approximately $1.5 \mathrm{~mm}$ wide with two prominent adaxial ridges (Fig. 7B2); their xylem strand (about
$0.3 \mathrm{~mm}$ broad) is abaxially curved, with two protoxylem poles present on the adaxial side. The next order corresponds to ultimate pinna rachides of similar outline but smaller (about $0.1 \mathrm{~mm}$ in diameter), with an
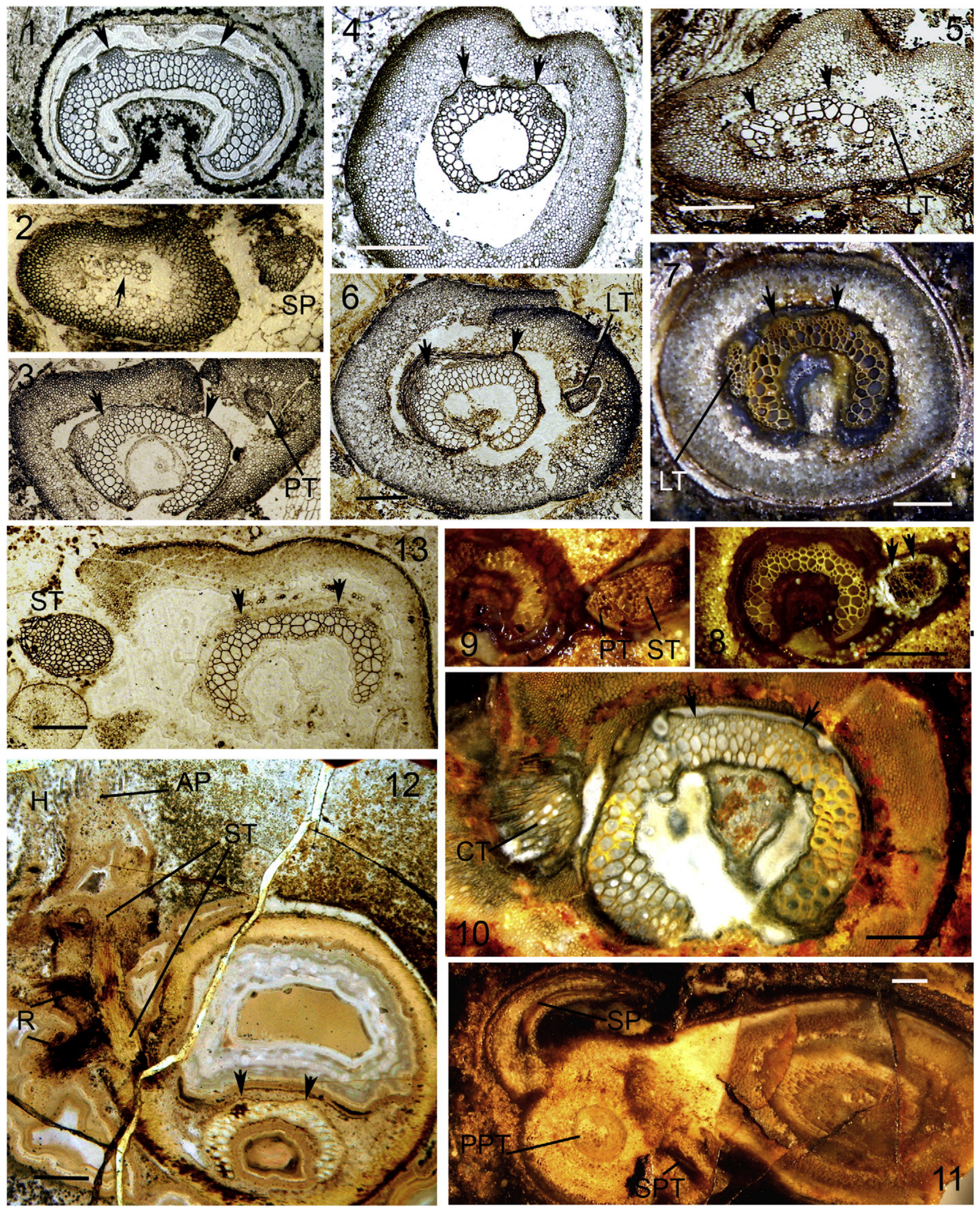

Plate IX (see caption on page 48) 

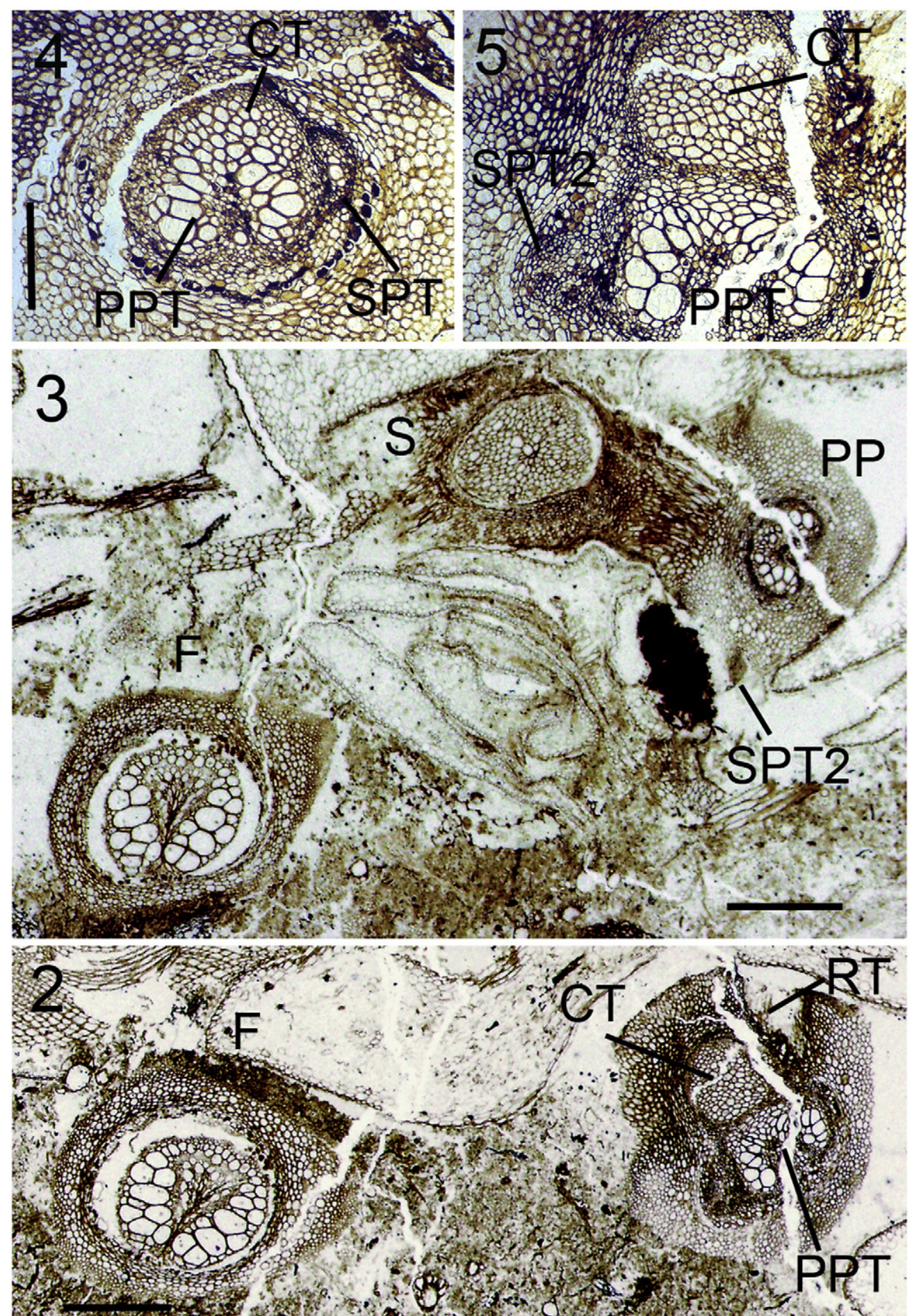

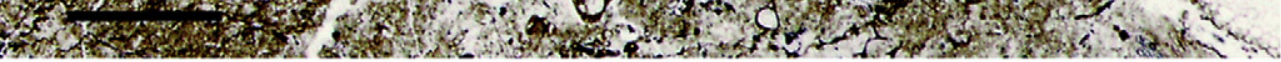

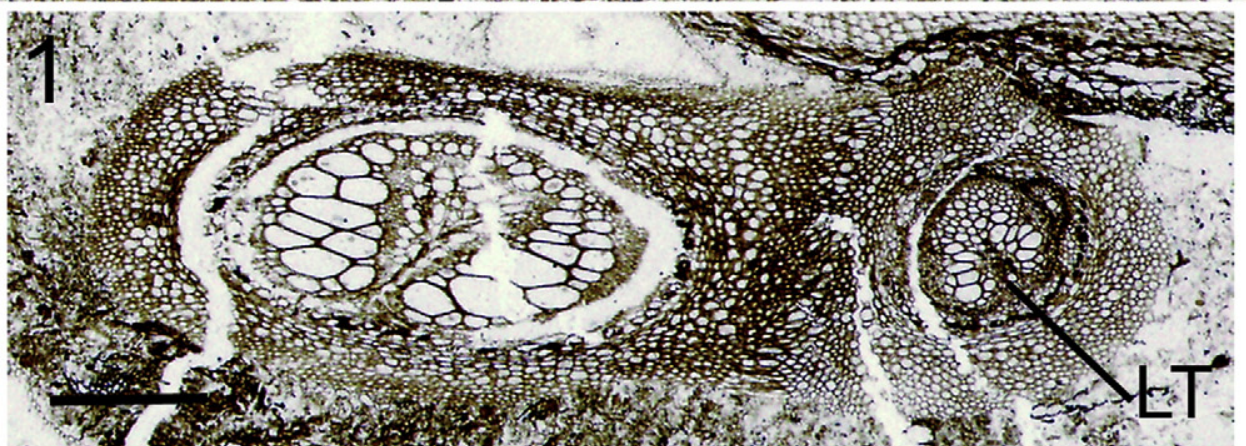


elliptical xylem strand and a single adaxial protoxylem (UP, Fig. 7B3). Traces to laminate pinnules diverge alternately and the lamina is confluent with the ultimate rachis but paradermal sections have not been obtained; size and shape of the pinnules have not been determined. Most illustrated specimens suggest that pinnule lobes had revolute margins (Fig. 7B4). The mesophyll is not differentiated into palisade tissue but consists of isodiametric cells of varying dimensions. However, the thickness of some illustrated pinnule lobes is suggestive of succulence (Fig. 7B5), a feature not mentioned by Rothwell.

Sporangia are attached on an expanded receptacle region of each pinnule lobe (Fig. 7B5). Sori consist of 25 to 35 oblong sporangia with a short, broad stalk (Fig. 7B6). The sporangium is up to $0.6 \mathrm{~mm}$ long and 0.45 in diameters; as in Sermaya the horizontal-oblique annulus consists of 2 interfingering rows of thick-walled cells. The trilete, subtriangular spores are assignable to the genus Leiotriletes.

Features of ultimate pinnae and pinnules, and morphology of sporangia and spores of Doneggia are similar to those of Sermaya and justified its assignation to the Sermayaceae. The family diagnosis takes into account characters of the sporangia but is rather vague with regard to sporangial distribution. However, Rothwell (1978) noted that Doneggia differs from Sermaya in features of pinna rachides (occurrence of adaxial ridges, and elliptical xylem in penultimate pinnae), revolute margins of pinnules, large sori of randomly disposed sporangia, and distinctly stalked and larger sporangia. The associated larger rachis of Anachoropteris belongs to the "involuta group" and this is an additional argument to separate the two genera.

\subsubsection{The Kaplanopteridaceae, from the American Late Pennsylvanian}

The family Kaplanopteridaceae (Tomescu et al., 2006) was based on the fern Kaplanopteris clavata, a novel combination for Anachoropteris clavata, of which the authors described the overall morphology of tripinnately dissected fronds. The primary pinna trace is abaxially concave and reniform proximally, becoming horseshoe-shaped more distally (P1, Fig. 7C1) while the secondary (ultimate) pinna rachis subtending the pinnule has a very small xylem strand (P2, Fig. 7C1). The pinnules have a very thin lamina and open dichotomous venation (Fig. 7C2). Fertile pinnules show superficial abaxial sori exhibiting gradate maturation. The sporangia are attached to a vascularized conical receptacle. Each sorus includes numerous sporangia tightly packed within a globose, urn-shaped indusium, 0.4-0.6 mm in diameter (Fig. 7C3-4). Sporangia are very small; they consist of a "bell-shaped capsule" (about $0.15 \mathrm{~mm}$ in diameter) with a transverse 2- to 3-seriate annulus and a long narrow uniseriate stalk (Fig. 7C5-6). Spores are scabrate, 18-25 $\mu \mathrm{m}$ in diameter, with a triangular contour. In agreement with the Sermayaceae, the fronds of Kaplanopteris have a frond anatomy of the Anachoropteris type and bear sori of annulate sporangia that are indicative of filicalean affinities. However, Kaplanopteris differs from the Sermayaceae in having indusiate sori with gradate maturation and sporangia with long, narrow stalks. In addition to differences in frond architecture with the occurrence of latent crosiers/reiterative buds, these differences in the fertile parts have been logically used by Tomescu et al. (2006) as arguments supporting the separation of this fern in a distinct family.

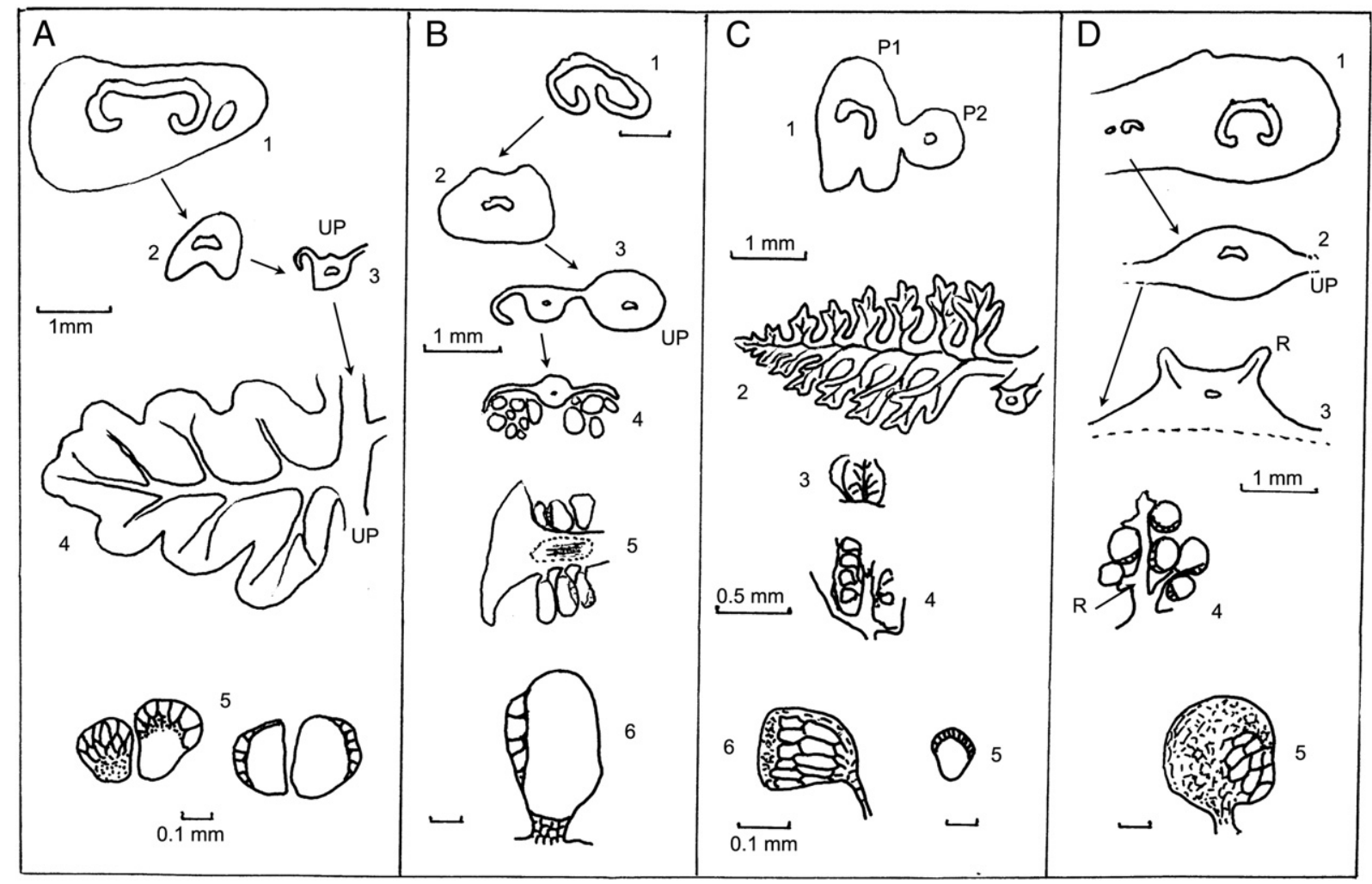

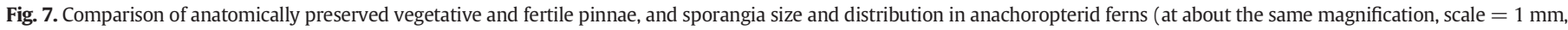

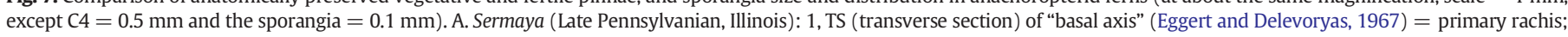

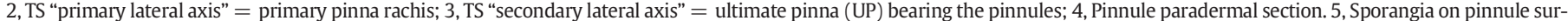

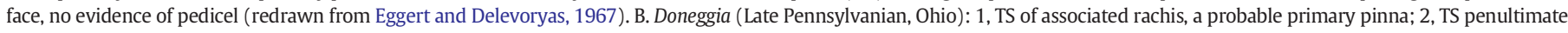

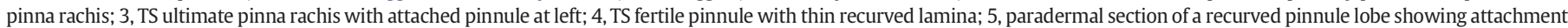

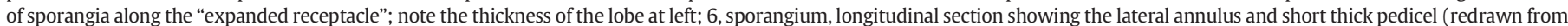

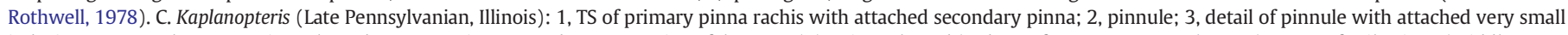

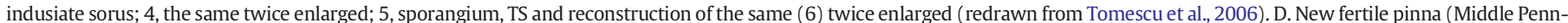

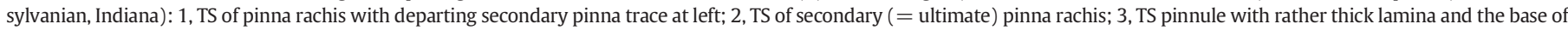

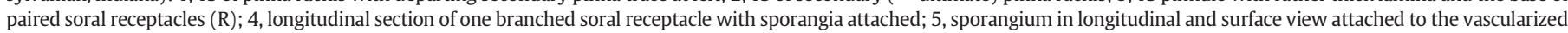
soral receptacle. 
3.7.3. New Anachoropteris fertile pinnae, from the American Middle Pennsylvanian

In documenting the diversity in fertile fronds with anachoropterid anatomy we illustrate on Plate XI details of two fronds from the Middle Pennsylvanian Murphysboro Equivalent Coal (Cayuga, Indiana) which differ from the Sermayaceae and Kaplanopteridaceae in a number of major features. In transverse section the whole fertile system measures about $9 \times 11 \mathrm{~mm}$ (Plate XI, 1 ). The main axis, about $2 \times 1.7 \mathrm{~mm}$ diameter, is interpreted as a primary pinna rachis (PP, Plate XI, 1-2); it shows a characteristic recurved xylem strand about $1 \mathrm{~mm}$ wide (Plate XI, 3), homogeneous cortex, an epidermis with small hairs and a slightly marked adaxial furrow. Secondary pinna rachides, about $1.3 \mathrm{~mm}$ broad at their base, are borne alternately; they extend first horizontally (Plate XI, 2), then they are adaxially upturned (Plate XI, 1). The secondary pinna xylem, at first C-shaped (SPT, Plate XI, 2), is only slightly curved more distally (UPT, Plate XI, 7) where the pinna cortex shows an outer zone of small thickened cells on the adaxial side, contrasting with a ground tissue of rather large cells. These pinna rachides, about $1 \mathrm{~mm}$ in diameter, correspond to ultimate pinnae bearing two rows of alternate pinnules (arrows, Plate XI, 1) which are confluent at their bases.

The pinnules are about $4 \mathrm{~mm}$ wide but they are strongly recurved (Plate XI, 6); as a result, their precise length and shape are not known. In its region of attachment (Plate XI, 4) the pinnule is very thick (0.6$0.8 \mathrm{~mm}$ ); the adaxial face with an outer zone of small thickened cells contrasts with the abaxial face showing large cells and hairs (Plate XI, 4). The pinnule mesophyll consists of rather large cells, except around vascular strands (Plate XI, 5). The pinnules are therefore characterized by a well marked dorsiventral anatomy and a rather succulent nature, their abaxial face being generally less well preserved.

The most interesting feature concerns the branched soral receptacles attached on the adaxial face of the pinnule, and occurring in paired parallel lines (R, Plate XI, 5, 6, 8, 9). The soral receptacles are up to $2 \mathrm{~mm}$ long and several times branched (R, Plate XI, 7-9, 12); the soral axis is 200 to $300 \mu \mathrm{m}$ in diameter proximally with a tiny branched vascular strand extending distally, up to the region of sporangial attachment (Plate XI, 7-13). In several sori there are basal receptacular branches with attached small sporangia which represent earlier stages of development and some examples of collapsed sporangia (arrows, Plate XI, $8,9)$. These are indicative of gradate development, as supported by the sequence of sporangial sizes shown on these figures and the basalmost location of more mature sporangia, as shown on Plate XI, 7, 9-10, 12.

One fully developed sporangium in longitudinal section with a short stalk is shown attached to the end of a receptacle branch (S, Plate XI, 13 ). The sporangia are spherical, about $0.4-0.5 \mathrm{~mm}$ in diameter, with a short stalk/pedicel and an oblique lateral annulus consisting of two rows of thick-walled cells. The annulus position is low on one face near the stalk as shown in longitudinal sections and in surface view (S, Plate XI, 7, 11-13). The dehiscence zone consists of narrow elongate cells (arrows, Plate XI, 10) extending down near the base. The spores, about $30 \mu \mathrm{m}$ in diameter, are immature.

\subsubsection{Discussion}

These American Middle Pennsylvanian fertile anachoropterids are distinct from the Sermayaceae and Kaplanopteridaceae with regard to major features. The first concerns the occurrence of sori superficially borne on the adaxial, instead of abaxial, side of the pinnules; secondly, the sorus is upright and it consists of a multi-branched vascularized stalk, up to $2 \mathrm{~mm}$ long, bearing the sporangia terminally. The adaxial location of the sori on the pinnule is a unique feature, and an exception amongst the ferns. Upright gradate sori are also known in the living Hymenophyllaceae and in the fossil Kaplanopteris. In both cases, the receptacle is not branched and the sori are indusiate, a feature absent in the new specimens. In the Hymenophyllaceae, the sori are at the apices of ultimate segments or on the margin of lobes (Iwatzuki, 1990) and not superficial on the pinnule. In Kaplanopteris, both the sori and the sporangia are of considerably smaller size as illustrated by the comparison of Fig. 7C3-6 and D4-5. Furthermore, the sporangial morphology of Kaplanopteris with its broad annulus and long unicellular stalk (Fig. 7C6) is significantly different from that of the new Middle Pennsylvanian sporangia (Fig. 7D5) which are similar to those of Doneggia sporangia (Fig. 7B6). The succulence of the pinnules of the new Middle Pennsylvanian fertile pinnae is another feature in common with Doneggia. In conclusion, the American Middle Pennsylvanian Anachoropteris described in this paper with their adaxial shoots and such distinctive fertile pinnae represent a new taxon that will deserve to be distinguished at the familial level.

\subsubsection{Comparison with fertile parts preserved as compressions}

The similarity of Sermaya fertile parts to those of the extant Gleicheniaceae was noted by Eggert and Delevoryas (1967), who suggested that some Carboniferous compression materials, e.g. Oligocarpia previously assigned to the Gleicheniaceae, may represent fertile remains of plants related to Sermaya. They emphasized the fact that "vegetative anatomy of Sermaya is noticeably different from that of any member of the Gleicheniaceae". Oligocarpia actually possesses radial sori of sporangia with a lateral oblique annulus, and spores that are similar to those of Sermaya. However, the sporangia of Oligocarpia have been described and reconstructed as having a uniseriate annulus, as those of the Gleicheniaceae (Abbott, 1954; Brousmiche, 1983), in contrast to the biseriate annulus of Sermaya and Doneggia.

In a reinvestigation of Oligocarpia lindsaeoides, Psenicka and Bek (2001) emended the generic diagnosis of Oligocarpia, and they suggested that "Oligocarpia belongs rather to Sermayaceae, based on the fact that Oligocarpia possesses an annulus two-rows of thick-walled cells"; however, they did not document this feature and their sporangium reconstruction shows one uniseriate annulus. On one side, anatomy of stem and rachis of the Sermayaceae supports their distinction from the Gleicheniaceae and, on the other side, anatomical information is missing for Oligocarpia. In the absence of evidence of anachoropterid anatomy in Oligocarpia, we consider that it is premature to include this taxon within the Sermayaceae. Oligocarpia was precisely considered as the oldest example of filicalean fern with uniseriate annulus and subsequently attributed to the Gleicheniaceae on this basis only. Oligocarpia kepingensis from the Permian of China (Wang et al., 1999) and Szea (Zhaoqi and Taylor, 1988), another fern from the Permian of China with sori consisting of 20-30 sporangia with a uniseriate annulus, has been attributed to the Gleicheniaceae but the characteristic pseudodichotomous branching of gleicheniaceous fronds was not demonstrated.

Since the Early Carboniferous/Mississippian, anatomically preserved Paleozoic ferns attributed to the Botryopteridaceae were the first to possess sporangia with a lateral biseriate annulus (Galtier and Scott, 1985). Evolutionary changes, within the botryopterids, concern size and shape of the sporangium and annulus, as documented in Botryopteris antiqua (Galtier, 1970), Botryopteris cratis (Millay and Taylor, 1980), Botryopteris tridentata (Rothwell and Good, 2000) and Botryopteris globosa-Botryopteris forensis (Phillips and Andrews, 1965; Galtier, 1971). Rather similar sporangia showing slight differences in the orientation of the always biseriate annulus (oblique/horizontal) are known in the Pennsylvanian Sermayaceae, Kaplanopteridaceae, Psalixochlaenaceae and the Permian Skaaripteridaceae. All may be considered as evolutionary intermediate towards sporangia with a uniseriate (oblique/vertical) annulus, characteristic of modern Filicales (Galtier and Phillips, 1996).

In conclusion, there are no well established compression-impression assemblages assignable to anachoropterid ferns; this contrasts with the situation in ankyropterid ferns (Phillips and Galtier, 2011) where the identity of anatomically preserved Ankyropteris and of some Senftenbergia compressions was established on the basis of crossed evidence from both anatomical and morphological features of fertile pinnae. 


\section{Tubicaulis}

The genus Tubicaulis was established for solid exarch protostelic stems with petiolar xylem traces which depart the stele as a flat tangential band and ultimately assumes an inverted C-shape (see definitions in Stenzel, 1889; Corsin, 1937; Mamay, 1952). However, following the discovery of Tubicaulis stems with vitalized protosteles and cortical modifications, it appeared likely that there are at least two major evolutionary lines of Tubicaulis (Eggert, 1959; Phillips, 1974). Eight species, ranging from the Early Pennsylvanian to the Late Permian, are presently attributed to this genus.

\subsection{Tubicaulis stems with a solid protostele}

\subsubsection{Tubicaulis solenites, the type species}

The genus Tubicaulis was created by Cotta (1832), with the type species Tubicaulis solenites based on a silicified specimen from the Early Permian of Chemnitz, Germany. This taxon was described in more detail

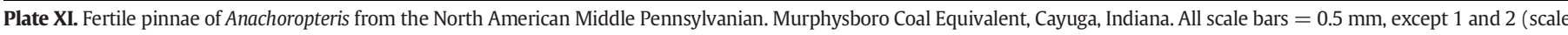
bar $=2 \mathrm{~mm}$ ).

2. More distal section of the same showing the pinna rachis with a departing secondary pinna (SPT) at left and traces to pinnules (arrows). UI25767FBOT253.

3. Detail of the involute xylem strand of the pinna rachis, transverse section. Note the departing secondary pinna trace (arrow). UI25767FBOT201.

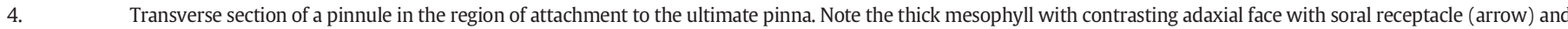
abaxial face with hairs (H). UI25767FBOT253.

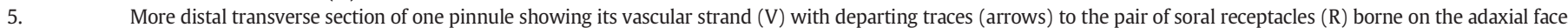
UI25767FBOT201.

6. Detail of one strongly recurved pinnule (abaxial faces and vascular strand arrowed) showing the attachment of one soral receptacle (R). UI25767FBOT165.

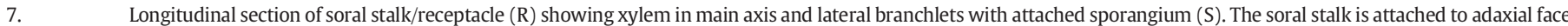
of the pinnule that is confluent with the ultimate pinna rachis, shown in cross section at right, with its slightly abaxial curved xylem strand (UPT). UI2626DBOT24.

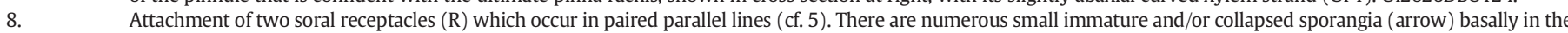
left receptacle. UI2626DBOT71.

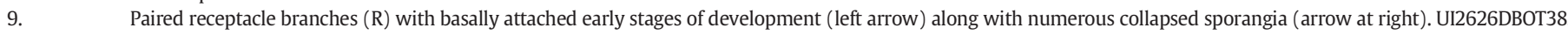

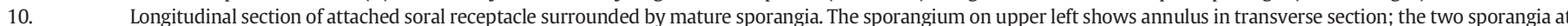
right are in surface view, showing the region of dehiscence with elongate parenchyma cells (arrow). UI2626DBOT97.

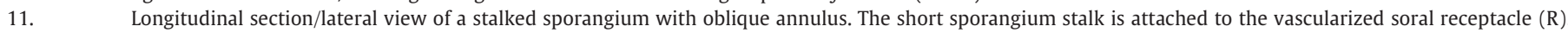
UI2626DBOT94.

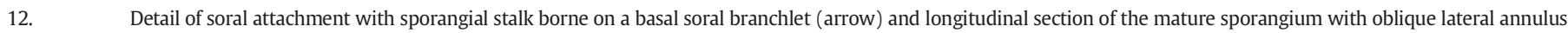
UI2626DBOT48.

13. A large sporangium with stalk attached to soral receptacle (R). UI2626DBOT48. (see on page 26)

Plate XII. (see on page 56)

1-3. Tubicaulis solenites, the type species from the Early Permian of Chemnitz. Scale bars $=1 \mathrm{~cm}$ in $1 ;=5 \mathrm{~mm}$ in $2-3$. K4798 Naturkunde Museum Chemnitz

1. Transverse section of the trunk showing the central stem surrounded by the mantle of petiole bases and roots.

2. Transverse section of the stem showing the massive solid protostele with departing trace (1) and other leaf traces (2-5) in the cortex.

3. Transverse section of a petiole showing the slender xylem strand with sub-opposite small pinna traces (1-2) and paired dividing pinna traces (arrows) in the cortex.

4-9. Tubicaulis sutcliffii, Early Pennsylvanian of Shore, England. (Scale bars $=1 \mathrm{~cm}$ in 4, 6; $=5 \mathrm{~mm}$ in 5,$7 ;=1 \mathrm{~mm}$ in Fig; 8; = $0.5 \mathrm{~mm}$ in 9 ).

4. Transverse section of the basal region of the small trunk showing the stem $(S)$ and a few helically arranged petioles. NHM, HZ2.

5. Transverse section of the stem with solid protostele and three leaf traces (1-3) in the common cortex. NHM, HZ2

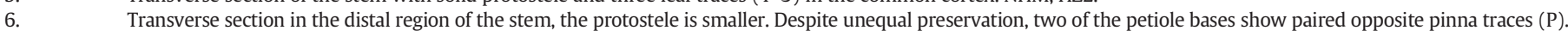
MMT18.

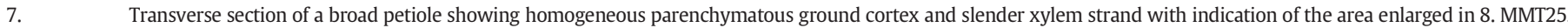

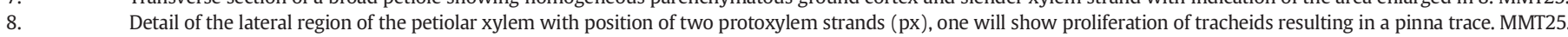

9. Transverse section of a small elongated pinna trace. MMT24.

Plate XIII. (see on page 57)

1-4. Tubicaulis berthieri, Early Permian, Autun, France. MNHNP3812 REN. (Scale bar $=1 \mathrm{~mm}$ except in $4=0.5 \mathrm{~mm}$ ).

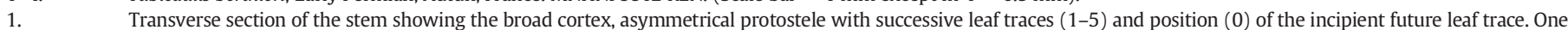
small pinna trace is pointed by the white arrow.

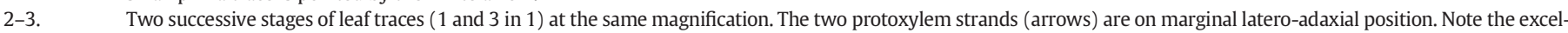
lent preservation of the phloem $(\mathrm{P})$ nearly surrounding the xylem in 3.

4. Detail of the cortex showing the small pinna trace (PT), and scattered groups of cells formerly described as "secretory" with black content lining their wall.

5-9. Tubicaulis grandeuryi, Late Pennsylvanian, Grand-Croix, France. (Scale bar $=1 \mathrm{~mm}$, except in $9=0.5 \mathrm{~mm}$ ).

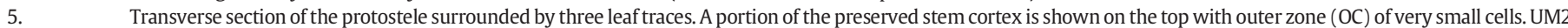
GC560CB.

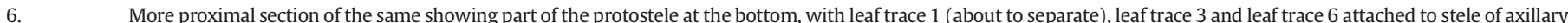
shoot (S). UM2 GC560AT.

7. Detail of the leaf trace 3 with the two protoxylem strands (arrows) in latero-adaxial position like in T. berthieri (3). UM2 GC560CB.

8. Transverse section of a free pinna in the process of division. UM2 GC560CB.

9. Detail of the stem middle cortex showing large "secretory" cells. UM2 GC 560DB.

10-16. Tubicaulis stems with parenchymatized protosteles from the American Middle Pennsylvanian. Scale bars = $1 \mathrm{~mm}$ in $10-12$; $=0.5 \mathrm{~mm}$ in $13-16$.

10. Tubicaulis sp., Shuler Mine, Iowa; transverse section of the protostele with one incipient leaf trace and one leaf trace (arrow) at left. UI524762BTOP3.

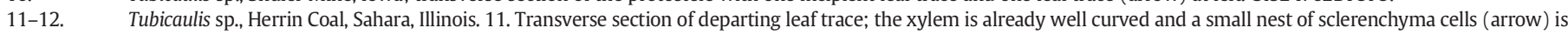
present in the abaxial concavity. Compare to 3 and 7 at the same stage. Protoxylem strands are hardly discernible. 12. Detail of a more distal petiole, at the same magnification, showing the thinning of the xylem strand and part of the very large sclerenchyma strand filling its abaxial concavity. UI4483-19.

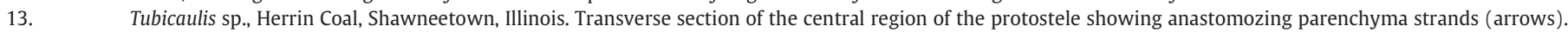
UI39635A1-BOT32.

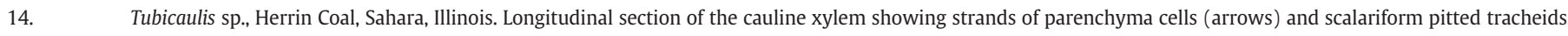
UI45776-1.

15. Tubicaulis sp., Herrin Coal, Sahara, Illinois. Longitudinal section in the petiole through the sclerenchyma strand, adaxial to the xylem (X) at right. UI21286BBOT39.

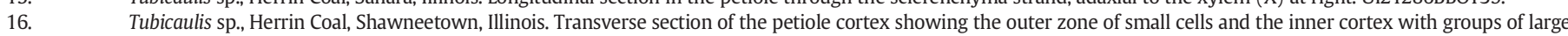
specialized cells (?secretory). These cells appear similar to those of 4 and 9 (same magnification). UI38896KTOP-37. 
by Stenzel (1889) as a fragment of trunk about $40 \mathrm{~cm}$ high with a basal diameter of $14 \mathrm{~cm}$; the central stem, $1.5-2 \mathrm{~cm}$ broad with a solid protostele up to $6 \mathrm{~mm}$ in diameter, was surrounded by a thick mantle of persistent leaf bases and adventitious roots (Plate XII, 1 ). Stentzel accu-

rately illustrated the helically arranged petiole traces departing as a

small tangentially flat xylem strand, becoming slightly abaxially curved

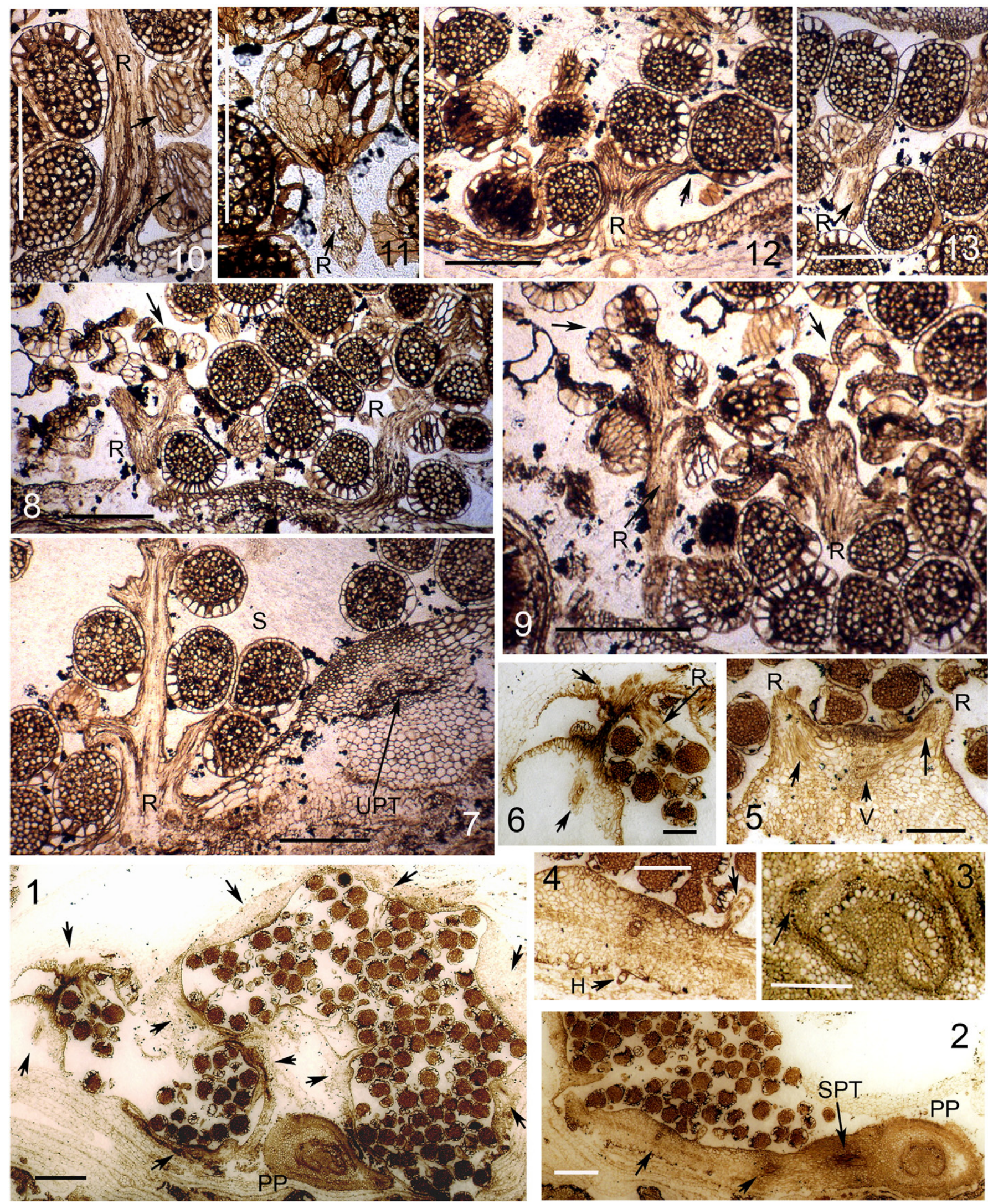




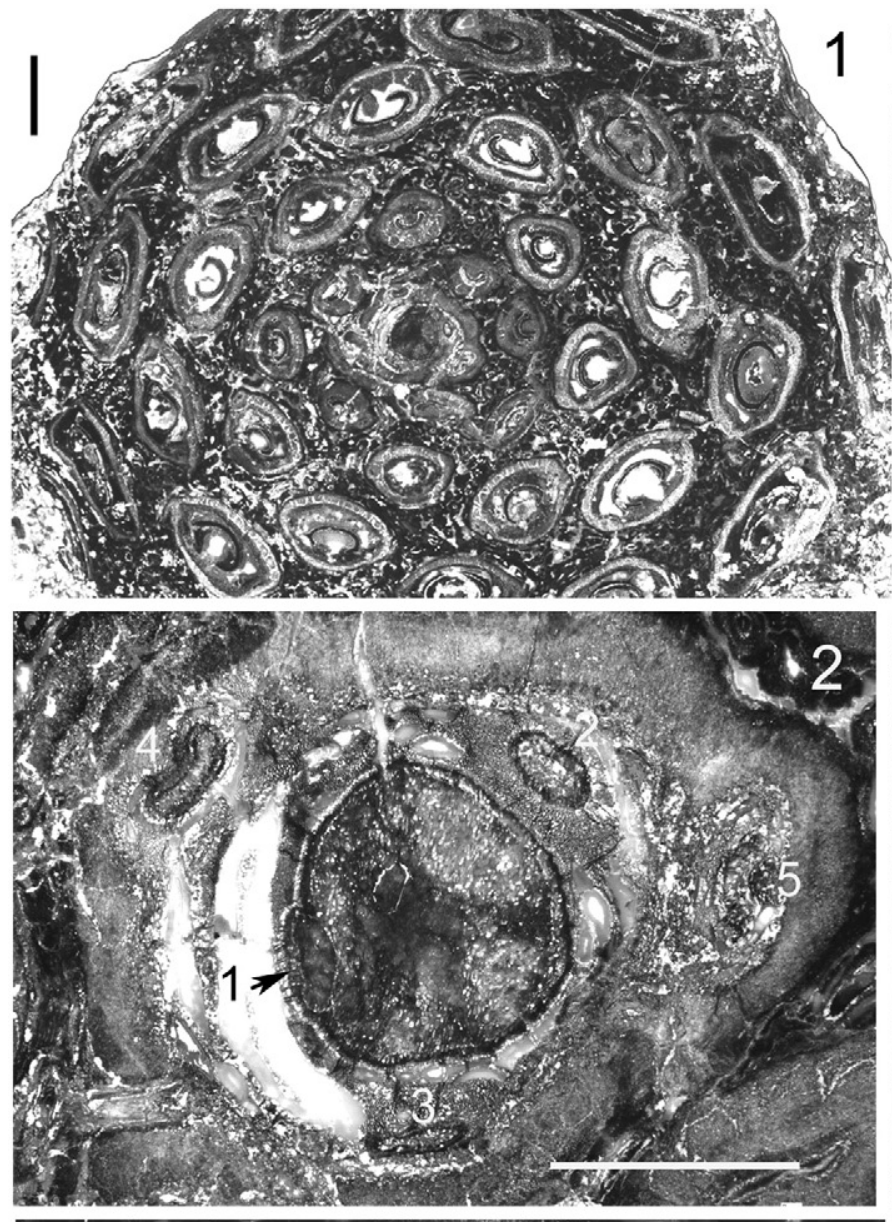

\section{4.} -

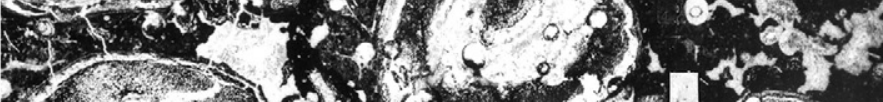

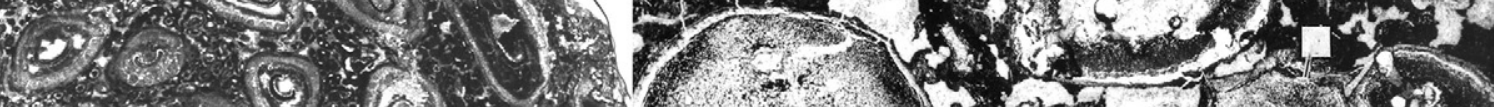
s. (4)

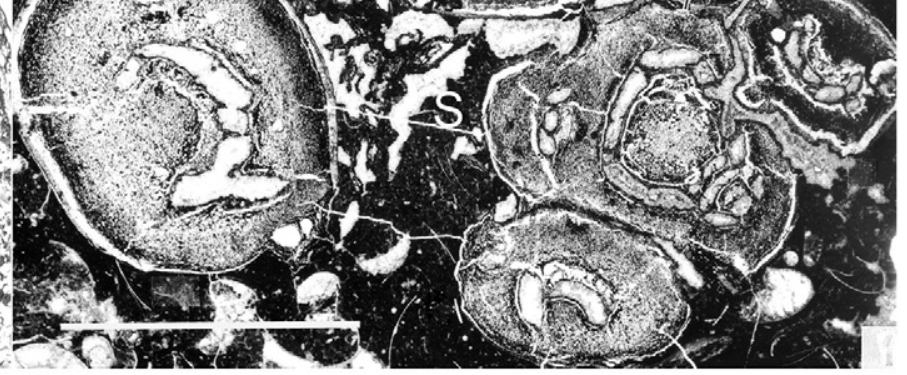
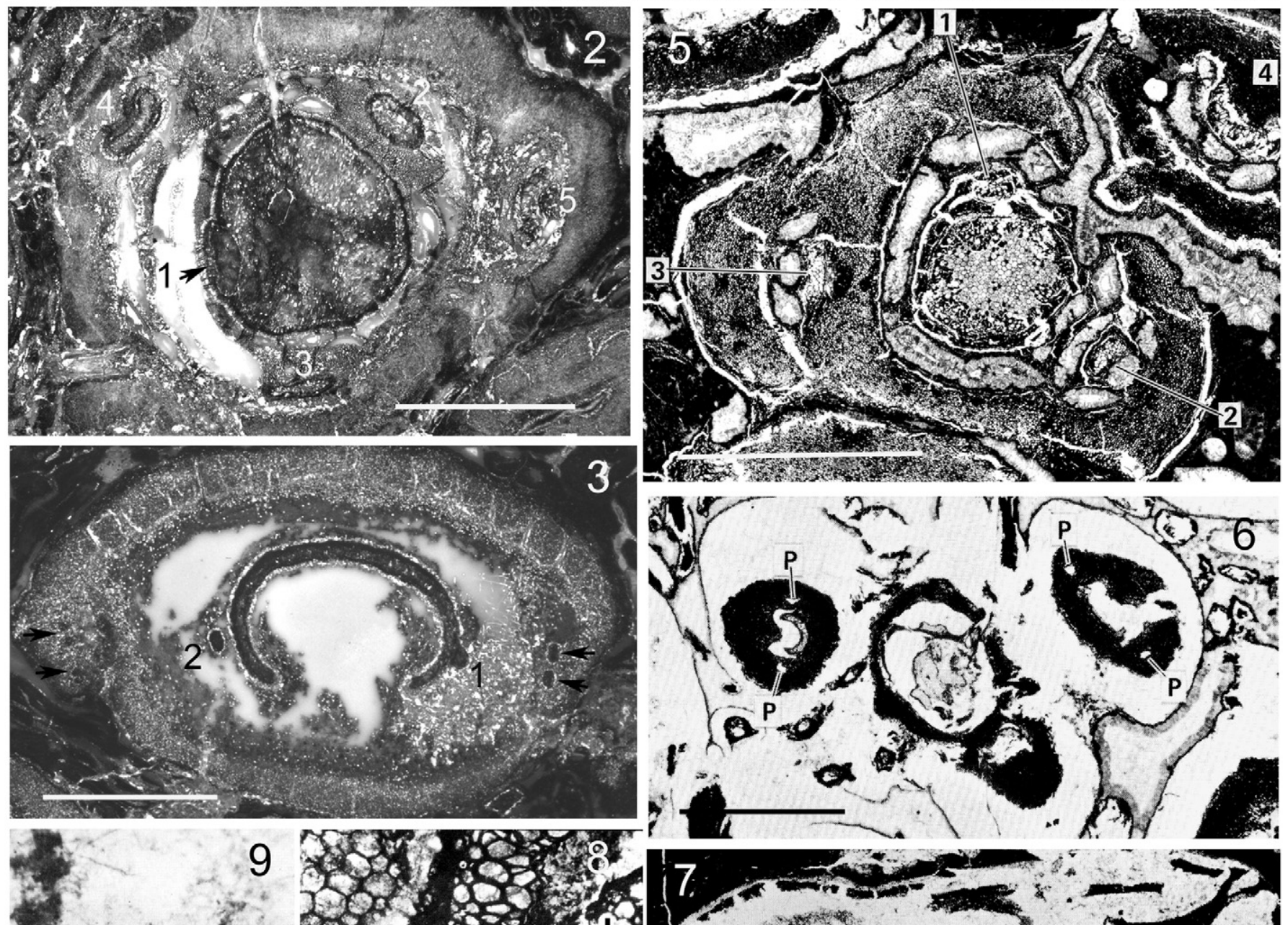

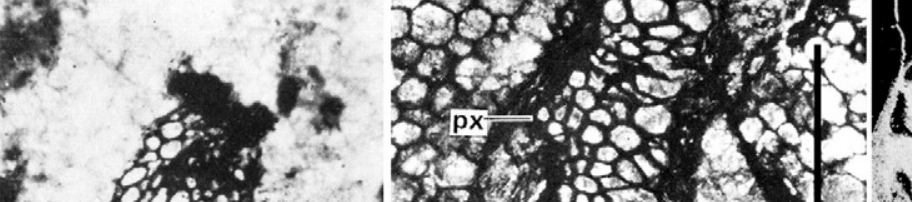
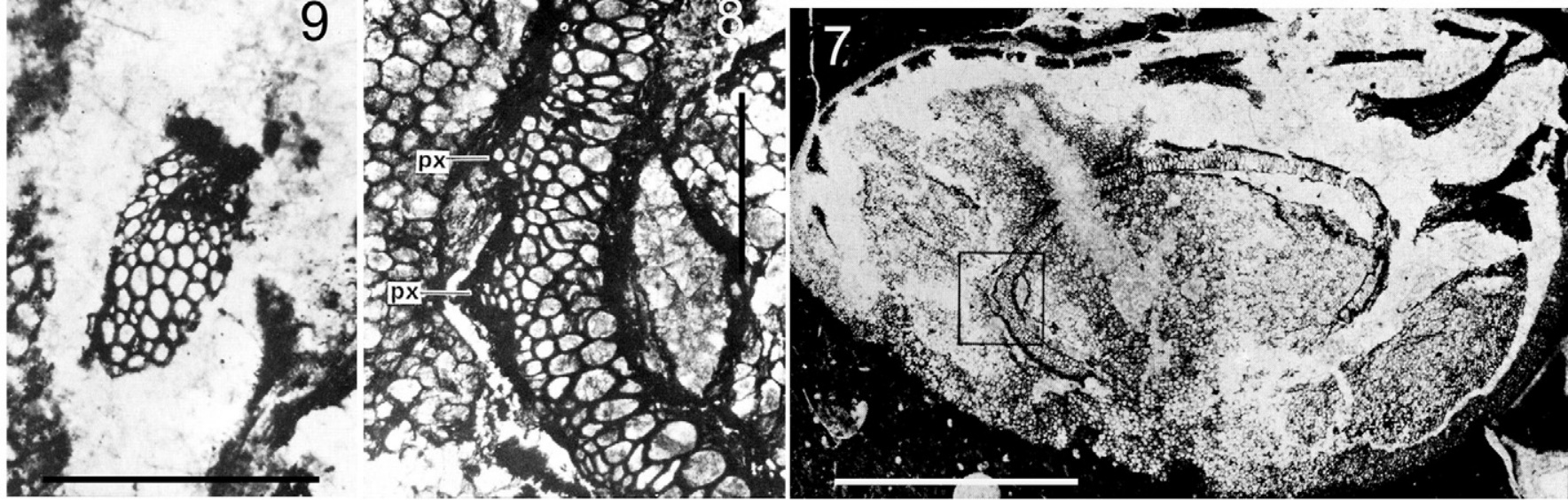
in the stem cortex where up to five petiole traces are visible (arrows, Plate XII, 2). It is only inside the free petiole that the xylem was assuming the inverted C-shaped (Plate XII, 3). Petiole traces with basal dimension of about $1 \mathrm{~mm}$ gradually increased to more than $10 \mathrm{~mm}$ width. Accordingly, the petioles are only $6 \mathrm{~mm}$ broad when they separate from the stem cortex but they increase to more than $20 \mathrm{~mm}$ in
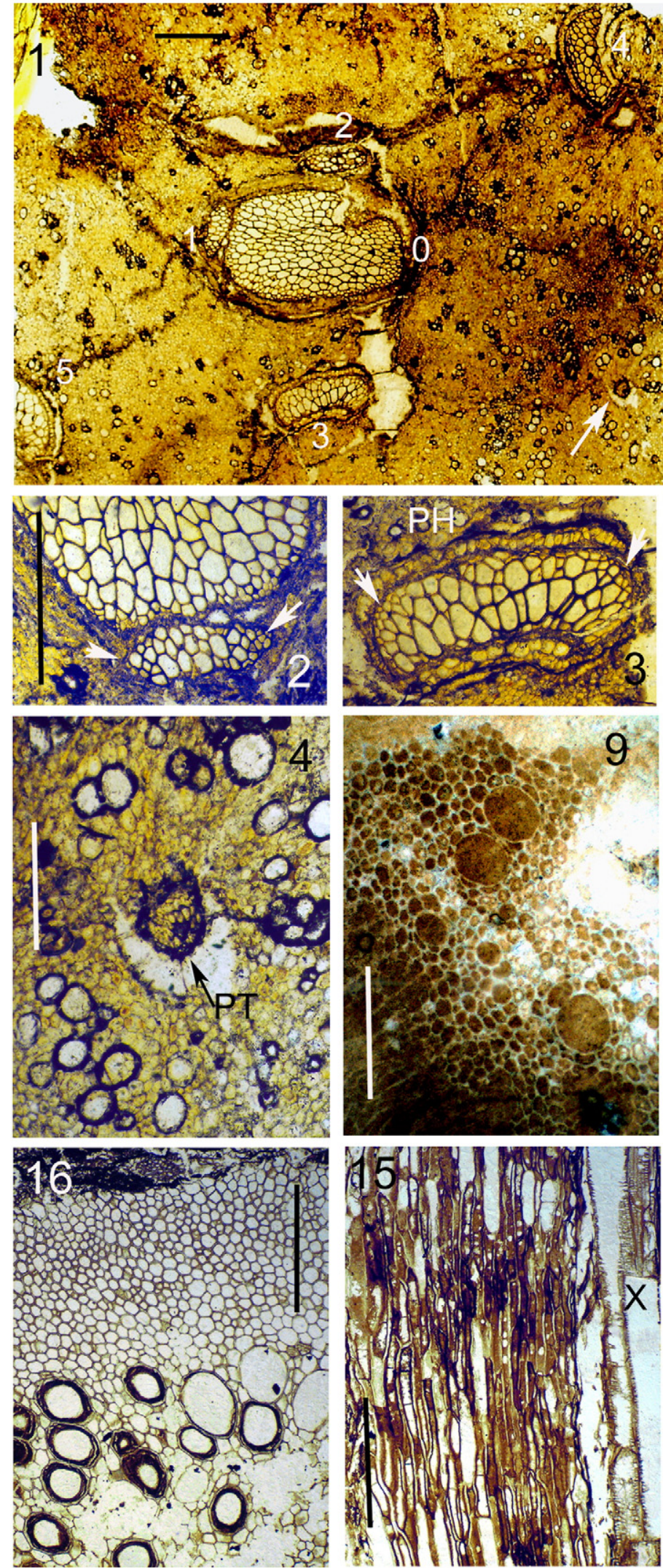
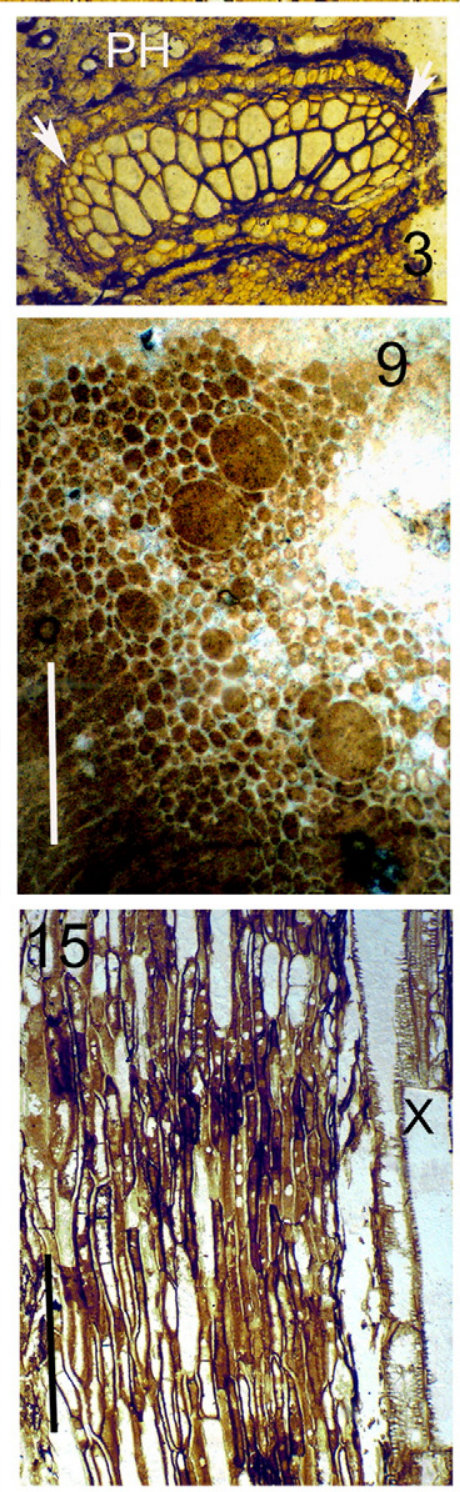

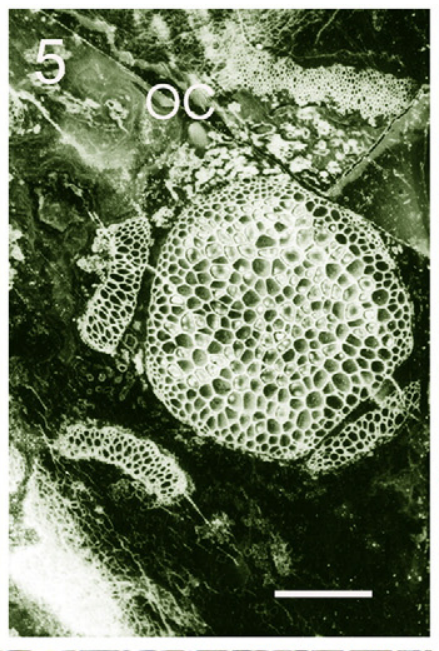

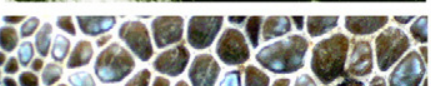
3028 - 120 rN
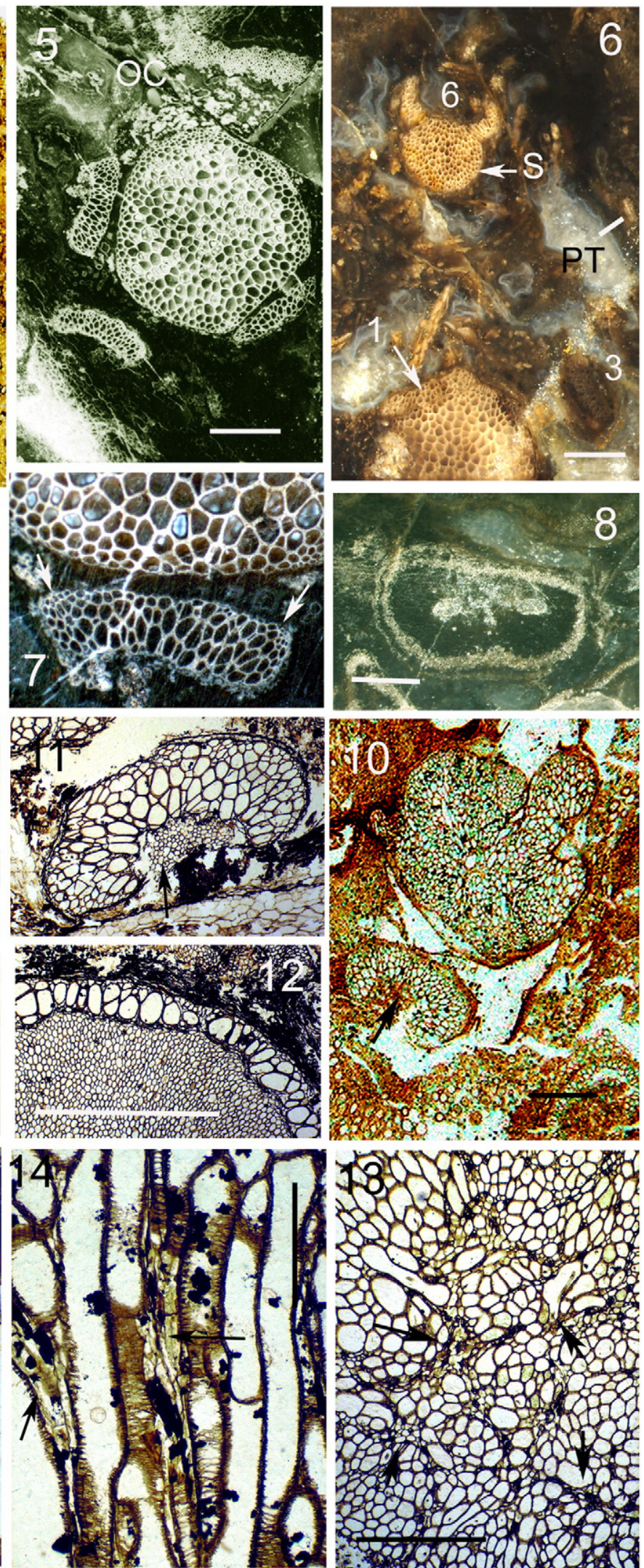

Plate XIII (see caption on page 54). 
diameter distally, at the periphery of the mantle of leaf bases (Plate XII, 1). The angle of departure of petioles is about $20^{\circ}$.

The emission of sub-opposite pinna traces is initiated very early in the free petiole. According to Stenzel (1889, Plate I, 4) the pinna xylem strand appears as a small bulge at the edge of the adaxial surface of the petiole trace. This was confirmed by photographic pictures in Bertrand (1909, Plate XV, 106-107). A number of successive subopposite pairs of pinna traces depart from the very proximal region of the petiole. While the petiole/primary rachis xylem is becoming more and more curved distally, the pinna traces depart at some distance from the edge of the xylem strand (1-2, Plate XII, 3). Pinna traces are very small, oval in transverse section. Each trace quickly divides in a radial plane. Pairs of pinna traces initiated more proximally are therefore visible as pairs on the left and right sides within the outer cortex of the same petiole (double arrows, Plate XII, 3). Finally, free pinna rachides are small cylindrical structures as illustrated by Stenzel (1889, Plate I, figs. 7-8, fg). We interpret these pinnae as morphologically equivalent to the dichotomizing "aphlebiae" that occur in two rows on the proximal region of petioles of the zygopterid ferns Symplocopteris (Hueber and Galtier, 2002), Zygopteris primaria (Sahni, 1932b), Etapteris illustrated in Phillips and Galtier (2005, Fig. 5H and Plate X, 5), and as well in the ankyropterid ferns Ankyropteris brongniartii and Ankyropteris hendricksii (Phillips and Galtier, 2011, Fig. 1C, F).

\subsubsection{Tubicaulis sutcliffii, the oldest species}

Tubicaulis sutcliffii Stopes (1906) was based on a single specimen, about $12 \mathrm{~cm}$ long, occurring in a roof nodule from the Upper Foot seam, Shore, Lancashire (Early Pennsylvanian, basalmost Langsettian); it represented the oldest known species of Tubicaulis. The specimen is smaller but similar to the type species. A mantle of petioles and adventitious roots ( $5 \times 10 \mathrm{~cm}$ in diameter) was surrounding the stem (Plate XII, 4). The stem had prominent petiole bases and solid protostele about $2.5 \mathrm{~mm}$ in diameter (Plate XII, 5). Stopes accurately described the emission of leaf traces becoming $\mathrm{C}$-shaped in the free petiole and the probable $2 / 5$ phyllotaxis. Roots are borne by the stems and petiole bases.

Holmes (1981b) re-investigated the type material of Tubicaulis sutcliffi. He studied the ontogenetical changes through the stem and the petioles, and the branching of the petioles. Some of his unpublished illustrations are reproduced on Plate XII, 4-9. The stem is very similar to that of $T$. solenites but only three leaf traces are visible on a section of the stem cortex (Plate XIII, 5). Initially the departing leaf trace has the form of a narrow band, $1 \mathrm{~mm}$ long and 3-4 tracheids in thickness; in the largest preserved petioles (17 $\mathrm{mm}$ in diameter) the xylem strand is up to $8-10 \mathrm{~mm}$ broad (Plate XII, 7). This represents an increase as much as eight to ten times the initial size of the strand, comparable to that observed in $T$. solenites. The largest foliar metaxylem tracheids show multiseriate scalariform pitting. The homogeneous ground cortical tissue of the petiole is parenchymatous (Plate XII, 7).

More importantly, Holmes established the emission of sub-opposite pairs of pinnae, a feature not clearly recognized by Stopes. Despite the rather poor preservation, pairs of pinnae are visible inside the cortex of two petioles still attached to the stem (p, Plate XII, 6). Holmes (1981b, fig. 31B) proposed an interpretation of the pattern of pinna trace emission. In the slender petiole xylem bundle the protoxylem strands are situated laterally (px, Plate XII, 7-8) rather than adaxially. On each side, there are two protoxylem strands; the one abaxially situated proliferates by the addition of small metaxylem tracheids, resulting in a minute pinna trace. Higher up, this trace separates and becomes oval-shaped $(0.5 \times 0.2 \mathrm{~mm})$ with one adaxial protoxylem (Plate XII, 9).

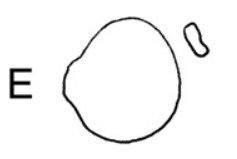

D<smiles>CC1=CCC[Se]1</smiles>

B

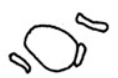

A
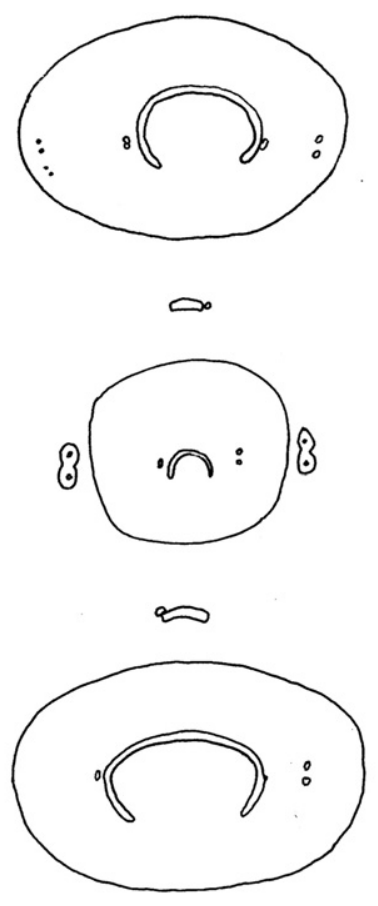
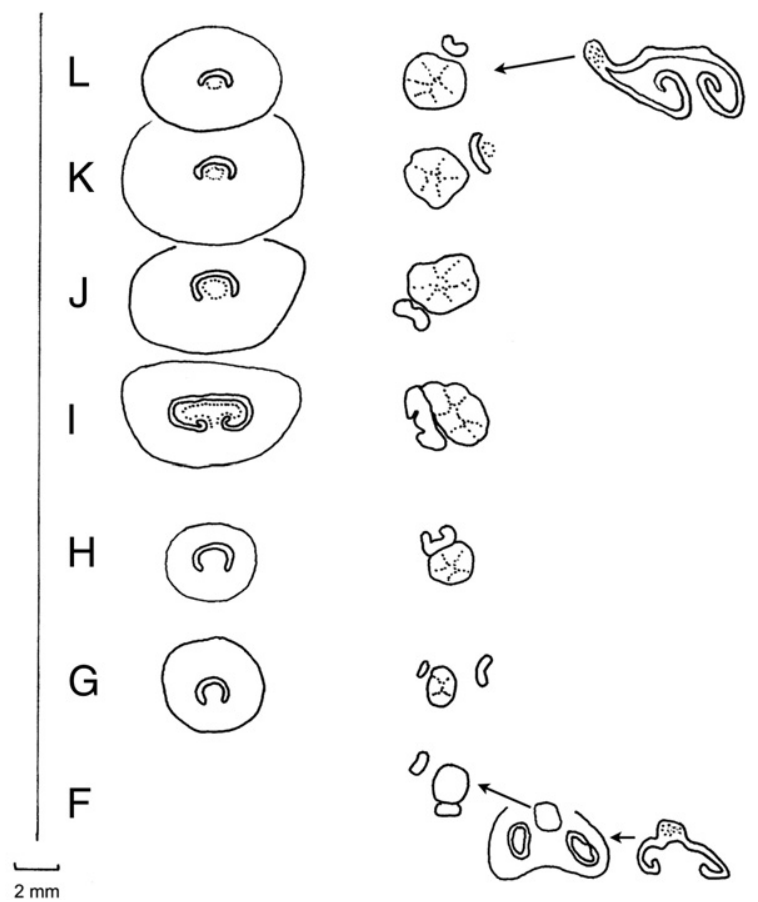

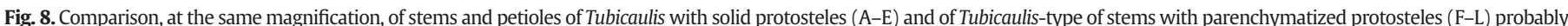

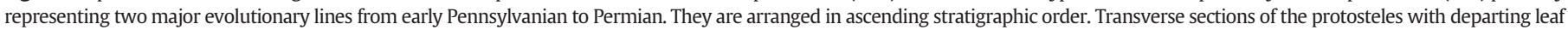

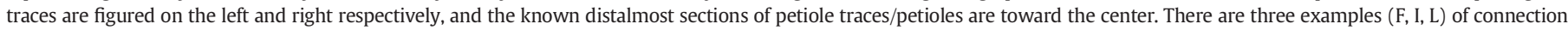

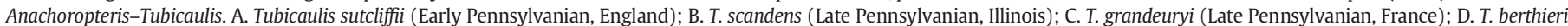

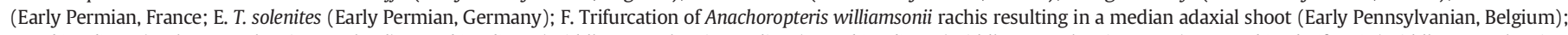

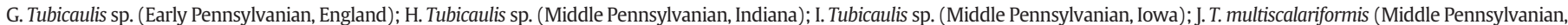
Kansas); K. T. stewartii (Late Pennsylvanian, Illinois); L. Anachoropteris involuta rachis bearing lateral shoot (late Pennsylvanian, France). Scale bar $=2$ mm.

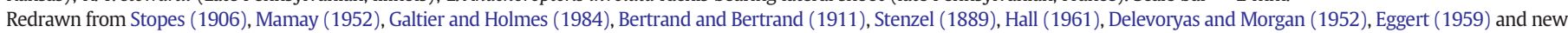
data. 
Interestingly, the petiole of Tubicaulis solenites shows the same pattern of the pinna trace emission with the trace on the right side still attached on the flank of the petiole xylem (Plate XII, 3). It is significant that, in both cases, the pinna trace is attached relatively near the abaxial tip of the recurved xylem bundle. This is different from the situation above described in Anachoropteris rachides (Section 3) where the two main protoxylem strands are adaxially situated and delimiting the rectilinear median region (= "apolar bar") while the "arms" are extending laterally and abaxially. In the petioles of Tubicaulis sutcliffii and T. solenites the median region is not rectilinear but curved and occupies the whole tangential width while the abaxial "arms" are firstly nonexisting then relatively short, even in large bundles.

\subsubsection{Other Tubicaulis stems with a solid protostele}

Tubicaulis berthieri (Bertrand and Bertrand, 1911) is a small silicified stem from the Early Permian of Autun, France. It is based on six thin sections which have been re-examined for this study. The stem, about $15 \mathrm{~mm}$ in diameter, is well preserved (Plate XIII, 1) but the outer cortex and petiole bases, as well as information about free petioles, are missing. The parenchymatous cortex is thick, homogenous and characterized by scattered groups of elongated cells described as "glandular" (Plate XIII, 4). The massive protostele is typically asymmetrical $(3 \times 1.7 \mathrm{~mm})$ and five leaf traces (1-5, Plate XIII, 1$)$ are visible in the stem cortex. The phyllotaxis is "pseudoverticillated" (Bertrand and Bertrand, 1911), the arrangement of leaf traces being sub-opposite and decussate (i.e. leaf traces 2 and 3 "alternate" with 4 and 5), a rather unusual feature in ferns. Leaf traces depart as a small flat xylem bundle $(0.85 \times 0.3 \mathrm{~mm})$ with opposite protoxylem strands (Plate XIII, 2); higher up, the trace enlarges $(1.4 \times 0.4 \mathrm{~mm})$ becoming slightly bent and surrounded by phloem (Plate XIII, 3); even the more distal leaf traces are only slightly abaxially curved and do not exceed $1.7 \mathrm{~mm}$ wide. Bertrand and Bertrand (1911, Pl. 3, 16) have illustrated the emission of one small circular trace $(0.2 \mathrm{~mm}$ in diameter) that may be interpreted as a precocious pinna trace. A similar trace is shown in the middle of stem cortex (arrow, Plate XIII, 1 and 4).

Tubicaulis scandens (Mamay, 1952) from a Late Pennsylvanian coal ball of Berryville, Illinois was the first known occurrence of Tubicaulis in American fossil floras. It is a slender stem $13 \mathrm{~cm}$ long and $20 \mathrm{~mm}$ in diameter, with a solid protostele varying in outline from nearly circular to irregularly elliptical, ranging from $2 \times 2.5$ to $2.3 \times 3.5 \mathrm{~mm}$. The petiole traces are helically arranged, departing as a narrow band of xylem 1$1.2 \mathrm{~mm}$ in length and $0.25-0.3 \mathrm{~mm}$ in width. They are gradually increasing to $4 \mathrm{~mm}$ in width and becoming $\mathrm{C}$-shaped. With one exception all the petiole traces lie within the cortex of the stem where up to eight petiole traces are visible in one transverse section. The petiole traces give off small pinna traces in sub-opposite pairs as reconstructed by Mamay (1952, text-fig. 3); the pinna trace division is unknown. Roots are initiated from the stele only. The stem outer cortex consists of thick-walled cells, the inner cortex containing two types of large nests of cells while the inner ground tissue is described as "spongy" with large thin-walled cells up to $170 \mu \mathrm{m}$ diameter. Mamay (1952) noted significant differences between the radially constructed and upright Tubicaulis solenites and Tubicaulis sutcliffii, and the rhizomatous dorsiventral $T$. scandens. In contrast, he considered that $T$. scandens bears a close resemblance to Tubicaulis berthieri in the size of the stele and of petiole traces, and the asymmetrical form of the stele; however, differences in cortical tissues support their specific distinction. Most importantly, Mamay demonstrated that $T$. scandens grew epiphytically on a Psaronius trunk, a feature previously mentioned, but not described in detail, by Bertrand (1909) and Sahni (1931) for Tubicaulis stems preserved among the roots of silicified Psaronius trunks from Chemnitz. Sahni (1935) tentatively referred these German Tubicaulis stems to T. berthieri (see below).

Tubicaulis grandeuryi (Galtier and Holmes, 1984) from the Late Pennsylvanian of Grand-Croix, France, is another small stem, with a solid circular protostele $2.75 \mathrm{~mm}$ in diameter. The petiole traces are helically arranged (Plate XIII, 5) and, like in the stems mentioned above, the petiole xylem departs as a narrow band $(1.1$ to $1.4 \mathrm{~mm}$ long and $0.3 \mathrm{~mm}$ thick) which becomes very slightly bent with the two protoxylem strands on the two latero-adaxial extremities (arrows, Plate XIII, 7). Petiole xylem is gradually increasing to $2 \mathrm{~mm}$ wide and becoming $\mathrm{C}$-shaped. The stem shows petiole bases and only the very proximal region of free petioles which are about $10 \mathrm{~mm}$ in diameter. As in Tubicaulis scandens, the petiole traces early give off small pinna traces which are visible in the stem cortex. At least three alternate pinna traces are present at the base of each petiole. Free pinnae are small cylindrical organs that quickly divide (Plate XIII, 8) like the pinnae of Tubicaulis solenites. Their distal morphology is not known. Roots are initiated from the stele only. The cortex is incomplete but the narrow outer zone of small thick-walled cells (OC, Plate XIII, 5) contrasts with the parenchymatous ground cortex with scattered very large cells (Plate XIII, 9). This tissue is suggestive of an aerenchyma but, on another hand, these cells are comparable to the supposed secretory cells of Tubicaulis berthieri (Plate XIII, 4).

The most important feature of Tubicaulis grandeuryi is the occurrence of axillary branching described for the first time in this genus. This is documented in several leaf traces that are associated with a cauline strand (S, Plate XIII, 6 ) in the form of a typical common trace. The branch xylem results from a proliferation of small tracheids on the adaxial side of the leaf trace; higher up the cauline xylem separates as a small cylindrical protostele about $1 \mathrm{~mm}$ in diameter, similar in reduction to the parent stem protostele. Interestingly, the adaxial proliferation of cauline tracheids did not disturb the precocious emission of pinna traces from the flank of the leaf trace.

Tubicaulis stems as epiphytes of Psaronius trunks from the early Permian of Chemnitz, Germany have been mentioned above and attributed to Tubicaulis berthieri by Sahni (1935). In a recent re-investigation of this material Rössler $(2000,2001)$ recognized more than 40 Tubicaulis shoots penetrating the free roots zone of Psaronius trunks. The stems are 15 to $35 \mathrm{~mm}$ in diameter with a solid protostele 2.3 to $6.5 \mathrm{~mm}$; the parenchymatous cortex contains nest of thick-walled cells. Leaf traces are helically arranged in a $2 / 5$ phyllotaxis. Of particular interest, axillary branching with the characteristic crescent-shaped common trace (Rössler, 2000, Plate III, 3) identical to that of Tubicaulis grandeuryi, is present. These stems have been referred to as Tubicaulis sp. and as T. cf. berthieri by Rössler $(2000,2001)$.

Despite differences in habit and ecology (see Section 4.4), the five Tubicaulis species discussed above share a number of fundamental characteristics: 1 ) a solid protostele, 2) the xylem of the departing leaf trace is in the form of a tangentially flat strand becoming slightly curved only within the stem cortex; 3 ) a small portion of the cauline xylem is involved in the formation of the leaf trace; 4) in the departing leaf trace one protoxylem group occurs at each end of the band of xylem, slightly towards the adaxial surface (i.e. nearly marginally); 5) in the development of the $\mathrm{C}$-shaped petiole xylem bundle the two protoxylem strands remain in latero-adaxial position while the median adaxial region enlarges significantly; 6 ) the petiole ground cortex is parenchymatous; and 7) there is precocious emission of pinna traces from the lateral edges of leaf trace and in the very proximal region of petiole. We consider that these features, present in the type species Tubicaulis solenites, are of generic value. In contrast, differences in protostele symmetry, in cauline and petiole cortical anatomy, in the more or less precocious emission of the pinna trace, and the occurrence of axillary branching allow distinguishing these species.

Both common features and specific differences are summarized in Fig. 8A-E which allows comparing sections of the five Tubicaulis species, at the same magnification; the protosteles with departing leaf traces are figured on the left, and the known distal sections of petiole traces/ petioles and of pinna traces/pinnae are on the right. Present data are supporting the idea that these species represent one major evolutionary line (corresponding to the generic concept of Tubicaulis sensu stricto) from the Early Pennsylvanian to the Permian. 


\subsection{Tubicaulis stems with parenchymatized protostele}

A second evolutionary line was proposed for Tubicaulis-type stems showing increasing stelar parenchymatization as first postulated by Eggert (1959). This trend is now demonstrable from the Early Pennsylvanian to the Late Permian (Phillips, 1974). Only three such species (T. multiscalariformis, T. stewartii and T. africanus) have been formally attributed to Tubicaulis. Fig. 8F-L summarizes, at the same magnification, features of stele with departing leaf trace and the distal most known section of petioles for selected members of this second evolutionary line.

\subsubsection{Tubicaulis from the Early Pennsylvanian}

The earliest evidence of a stem with a parenchymatized protostele is an unnamed species from the Early Pennsylvanian of England, briefly described by Millay (1970) who noted similarities with the American species Tubicaulis stewartii and Tubicaulis multiscalariformis. This stem has been illustrated for the first time in the present paper (Plate VII, 7 and Fig. 8G) and it is interpreted as probably representing the distal region of some epiphyllous shoot borne on an Anachoropteris williamsonii rachis (Plate VII, 4-6), as found in another contemporaneous English coal ball. It must be noted that this epiphyllous shoot had a solid protostele proximally but parenchyma becomes intermixed a little more distally. The petiole trace is at first a massive xylem bar which becomes C-shaped but not inrolled (Plate VII, 7; Fig. 8G). Pinna traces have not been observed. Isolated rachides with similar anatomy have been found in contemporaneous Belgian coal balls and referred to as “Anachoropteris sp.2" by Holmes and Fairon-Demaret (1984, Plate 3, fig. 7); this is not surprising because similar epiphyllous shoots of Tubicaulis-type also occur in Belgian coal balls from Bouxharmont (Plate VII, 1-3 and Fig. 8F). Lastly, isolated rachides with the same anatomy, from the slightly older Namurian C equivalent of Essen-Werden (Germany), are present in the collections of the University of Münster. They have been attributed to Tubicaulis by Professor W. Remy (H. Kerp, personal communication); they represent, indirectly, evidence of the oldest known Tubicaulis-type of stem.

\subsubsection{Tubicaulis from the American Middle Pennsylvanian}

Tubicaulis multiscalariformis Delevoryas and Morgan (1952) from a Middle Pennsylvanian coal ball of the Fleming Coal, West Mineral, Kansas, has been described as a small stem with a protostele, about $3 \mathrm{~mm}$ in diameter, showing multiseriate scalariform pitting of the largest metaxylem tracheids. The well documented successive stages of leaf-trace development show that the C-shape is apparent very early, before leaf trace departure (Fig. 8J). This feature is absent in the older European Tubicaulis-type of stems. Helically arranged petioles averaged $6 \mathrm{~mm}$ in diameter and the vascular strand, about $2 \mathrm{~mm}$ wide, possessed a nest of sclerotic cells within its abaxial concavity. Pinna traces have not been observed.

Another Middle Pennsylvanian stem (from the Carbon Hill Coal Mine, lowa), is considered as the first evidence of the attachment of petioles referable to Anachoropteris involuta to a Tubicaulis type of stem (Hall, 1961). A large portion (about 1/3) of the cauline xylem is involved in the leaf-trace formation. At their departure petiole traces are massive and C-shaped but they become involute distally (Fig. 8I). Xylem parenchyma is interspersed in radiating plates among the tracheids. Adventitious roots are borne on the stem. Hall (1961) proposed a new interpretation of the habit and ecology of this plant which will be discussed further on (Section 4.4).

Stems from the Middle Pennsylvanian Herrin Coal, Illinois (Plate XIV, 1-2) show features of parenchymatized stele (Plate XIII, 13) and leaftrace development, with the nest of small sclerotic cells within the abaxial concavity (Plate XIII, 11-12, 15), and middle cortex with large cells suggestive of a lacunar zone (Plate XIII, 16), all very similar to those of Tubicaulis multiscalariformis. Some petiole traces are becoming slightly inrolled distally (arrow, Plate XIV, 1) and suggestive of anachoropterid anatomy. Nevertheless, some isolated rachides from the same locality (Plate XIV, 3) show a C-shaped xylem strand more "typical" of a Tubicaulis petiole.

A second stem from the Middle Pennsylvanian (Shuler Mine) of Iowa is a long rhizome of which we illustrate one basal section (Plate $\mathrm{XIV}, 5$ ). The protostele is very parenchymatized (Plate XIII, 10); surrounding petioles with progressively inrolled xylem strands (P, Plate

\footnotetext{
Plate XIV. Tubicaulis stems with parenchymatized protosteles and petioles from the American Middle Pennsylvanian. Scale bars $=2 \mathrm{~mm}$, except $6-7$ bar $=0.5 \mathrm{~mm}$.
}

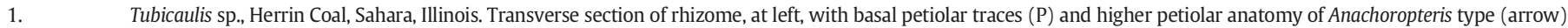
UI4483-19.

2. Tubicaulis sp., Herrin Coal, Sahara, Illinois. Longitudinal section of similar rhizome protostele (S) with departing petiole traces. UI45776-1.

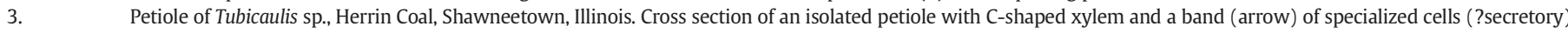
arching abaxially. See detail on Plate XIII, 16. UI38896KTOP-37.

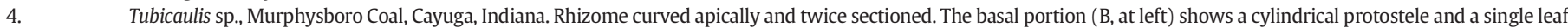
trace already C-shaped (arrow). The stem cortex is homogeneous. The apical most part (A, at right) is smaller in diameter, with an abundant ramentum. UI22753BTOP143.

5-7. Tubicaulis sp., Shuler Mine, Iowa. UI524762BTOP3. 5. Basal cross section of rhizome with petiole traces and surrounding petioles with progressively inrolled xylem strand (P), and numerous diarch roots (arrows). Detail of the protostele illustrated on Plate XIII, 10. 6. Detail of transverse section of stem cortex with outer zone of small diameter cells and middle cortex with abundant large cells. 7. Detail of the outer cortex and prominent hairs.

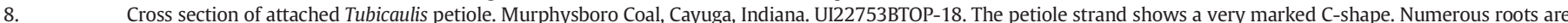
departing, some connected to the petiolar vascular system. An abundant ramentum $(\mathrm{H})$ is present.

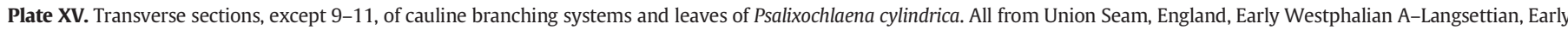
Pennsylvanian. Scale bars $=1 \mathrm{~mm}$, except $9-10=0.5 \mathrm{~mm}$. (see on page 62 )

1. Group of three developmentally old stems and one leaf (at right) sandwiched between the layers of bark of a Sigillaria stem. UM2 B36FA1

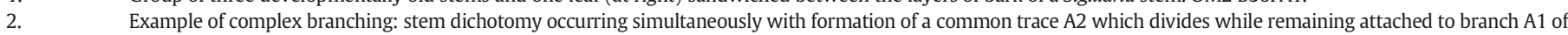
dichotomy; L, axillant leaf. UM2 TWDB02.

3. Isotomous dichotomy of a stem. UM2 B36DT02.

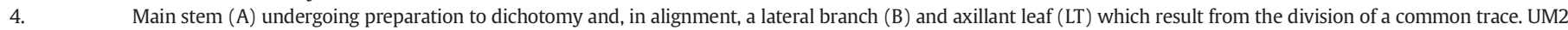
B48CB1.

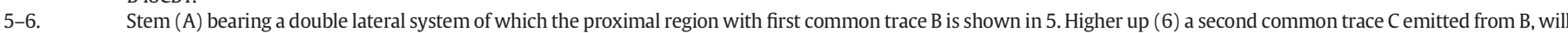
divide resulting in a second branch and axillant leaf. UM2 B77La1.

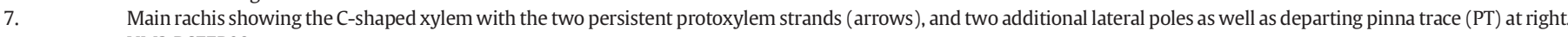
UM2 B67EB09.

8. Primary pinna rachis borne on the rachis of 7. UM2 B67DT94.

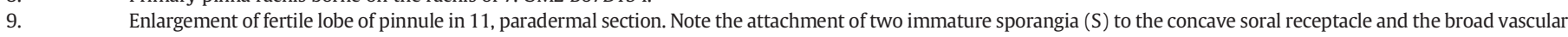
ending (V). UM2 B67EfH44.

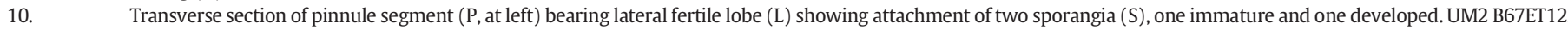

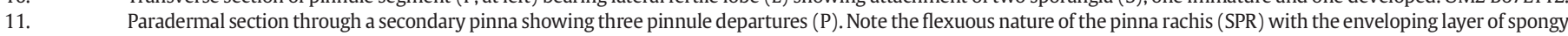
tissue. UM2 B67EfH46. 

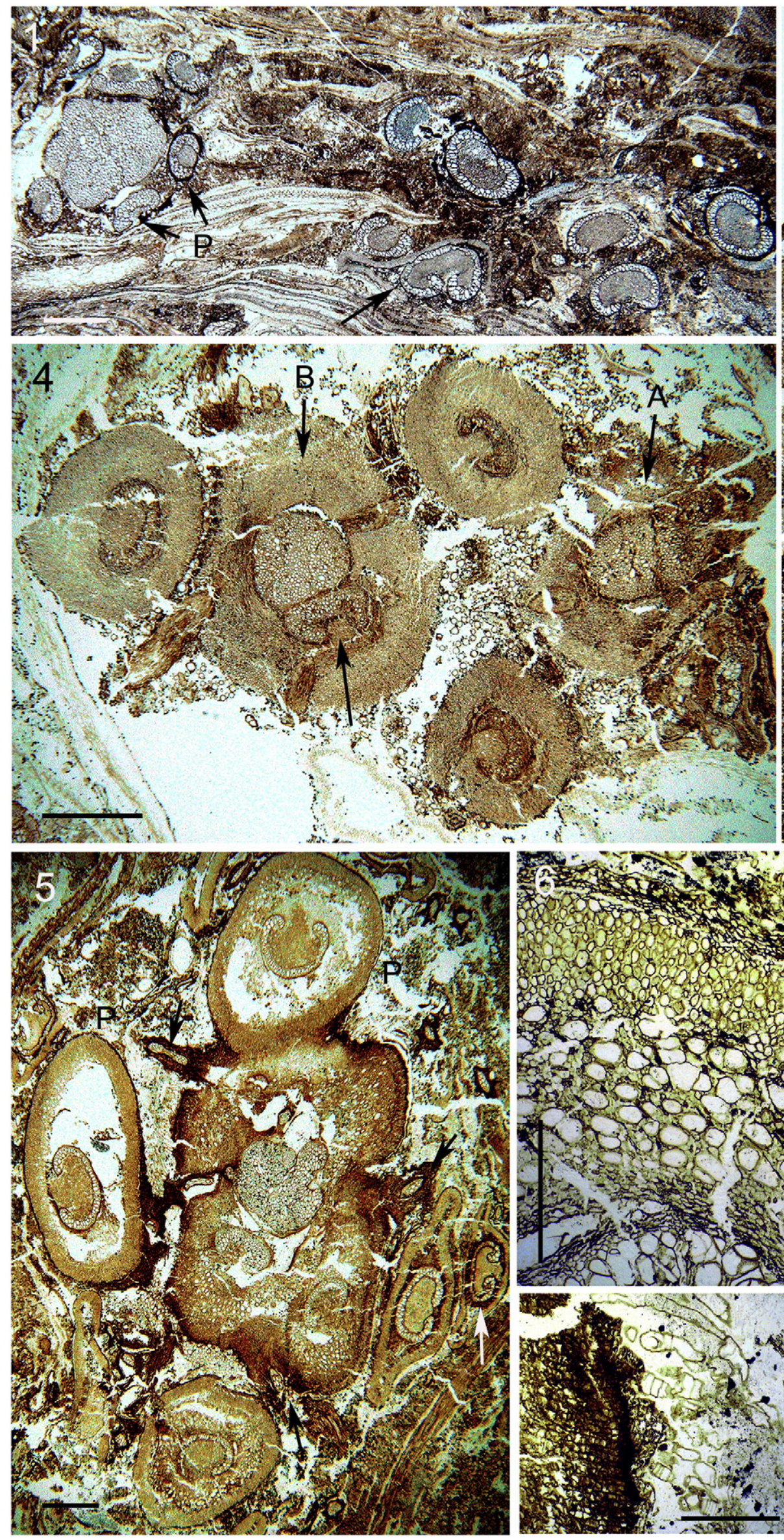
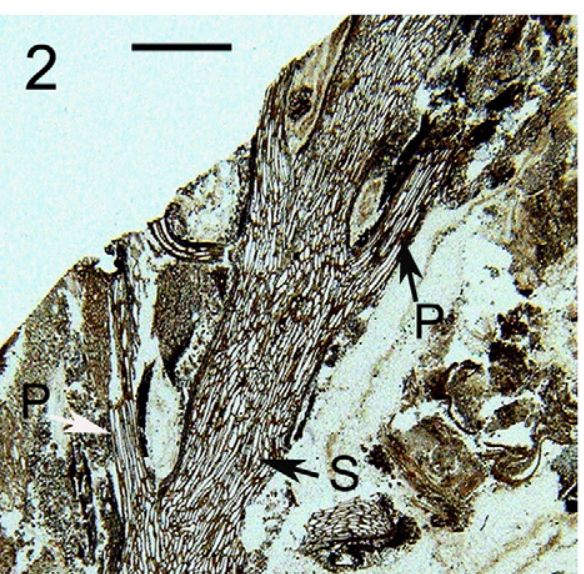
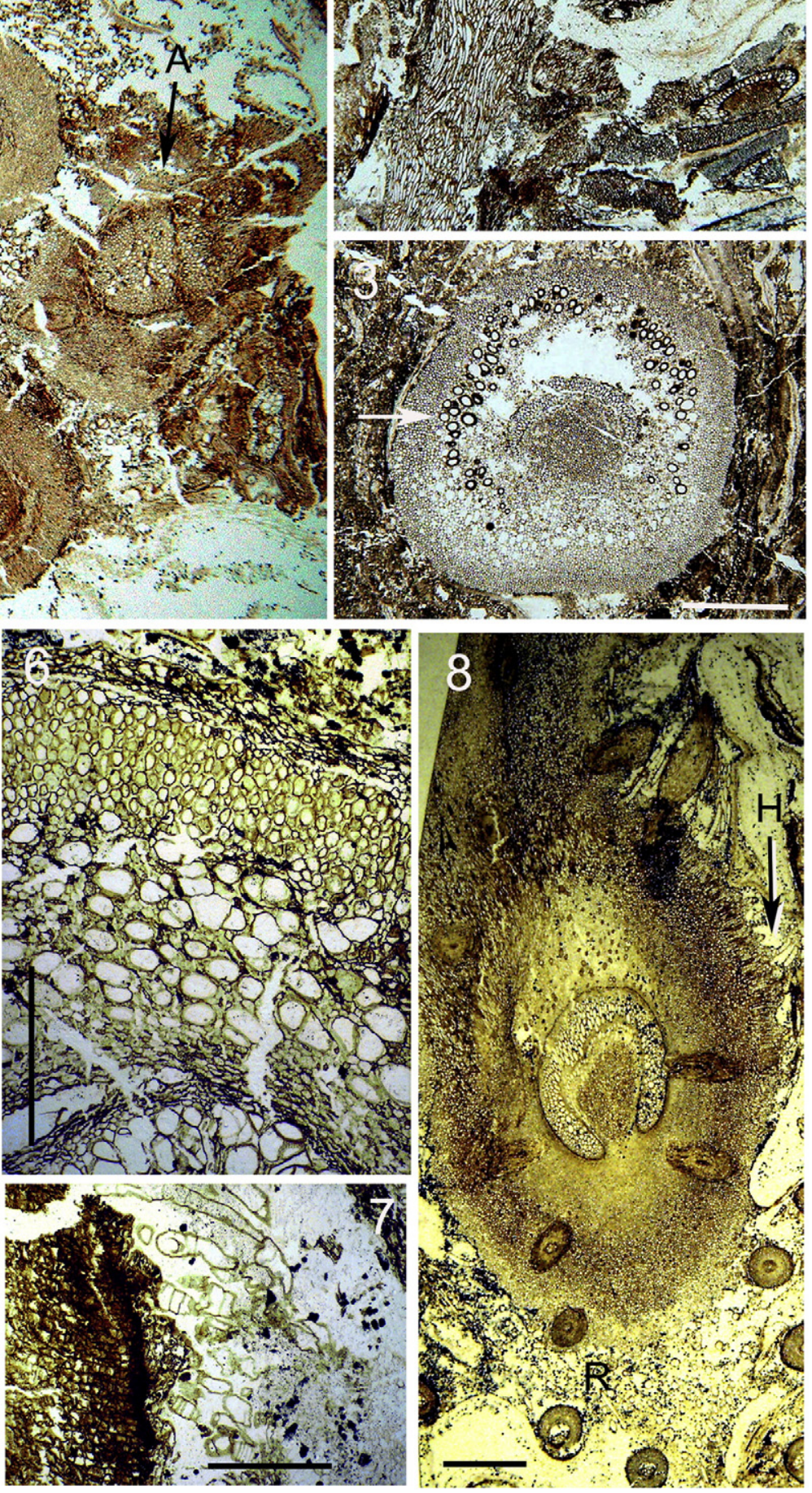

Plate XIV. 
XIV, 5) and numerous root departures are shown. Large cells are scattered in the cortex of the stem and proximal region of petioles (Plate XIV, 6) and abundant ramentum is present (Plate XIV, 7).
A third example of Middle Pennsylvanian stem (from the Murphysboro Coal, Cayuga, Indiana) shows a rhizome curved apically and twice sectioned (Plate XIV, 4). The protostele is less parenchymatized
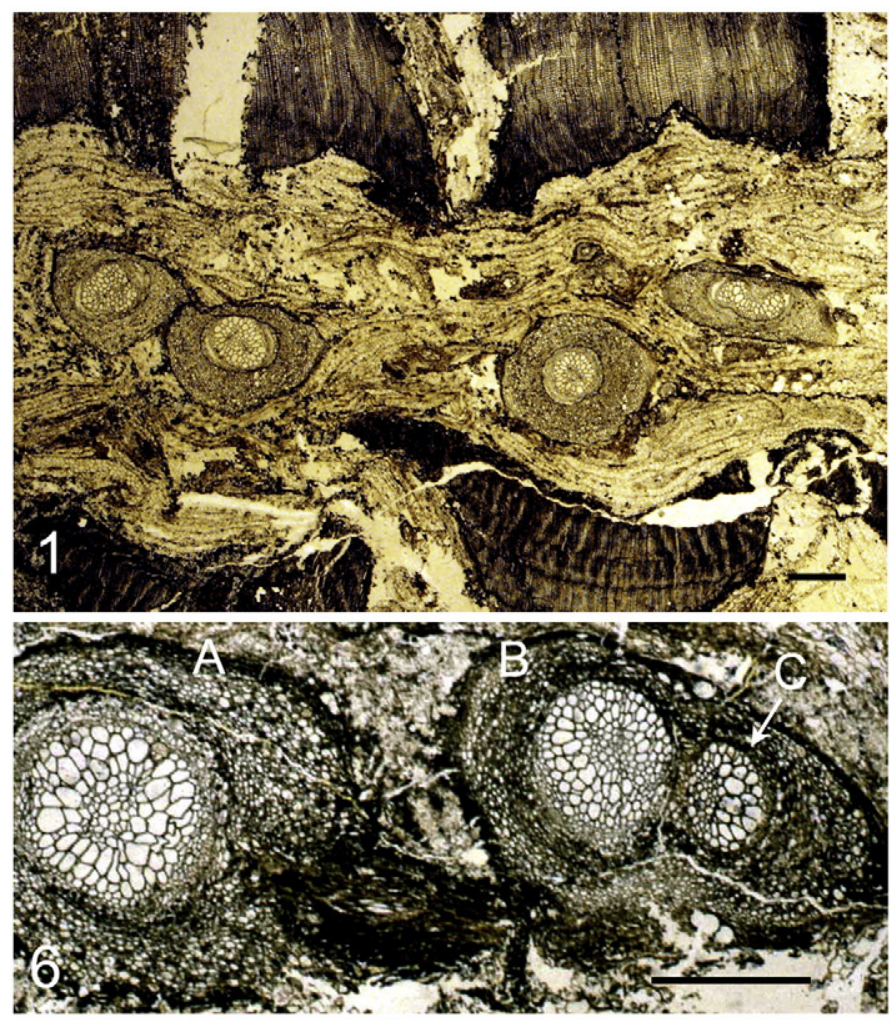

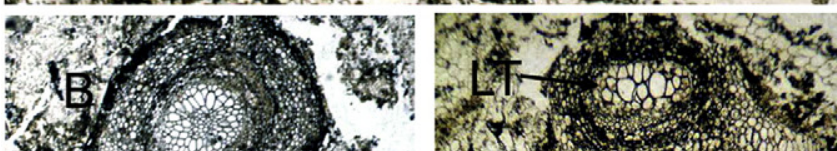

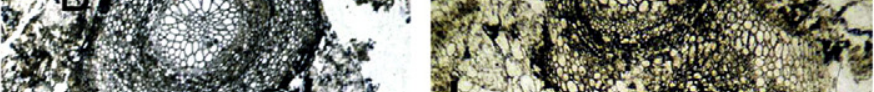

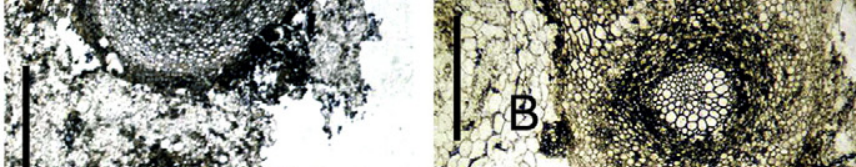

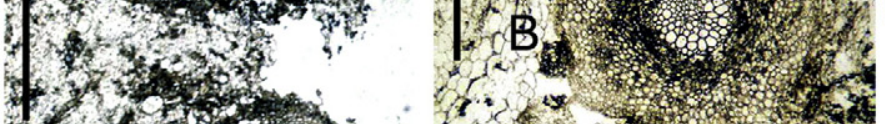

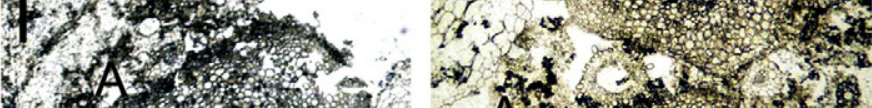

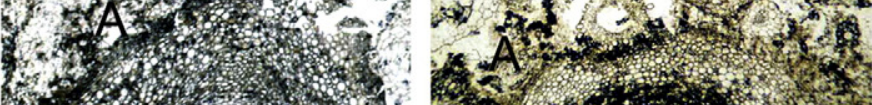

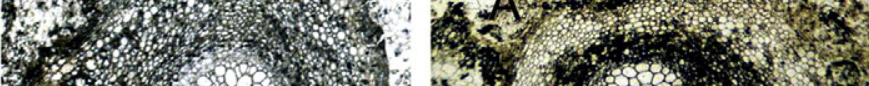

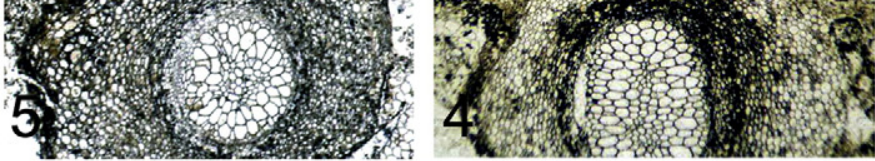

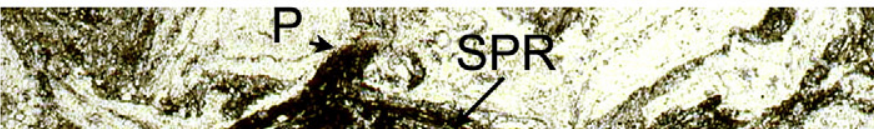

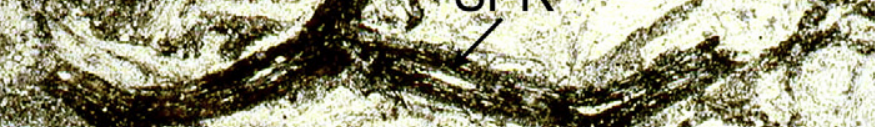

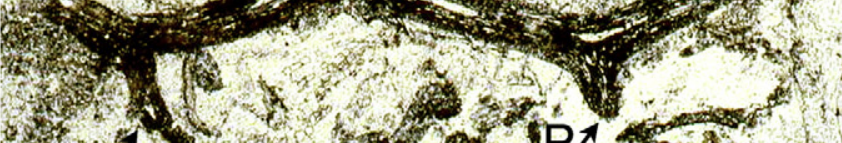

8.1.2.

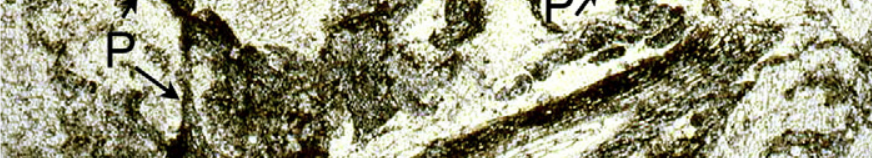

(2)

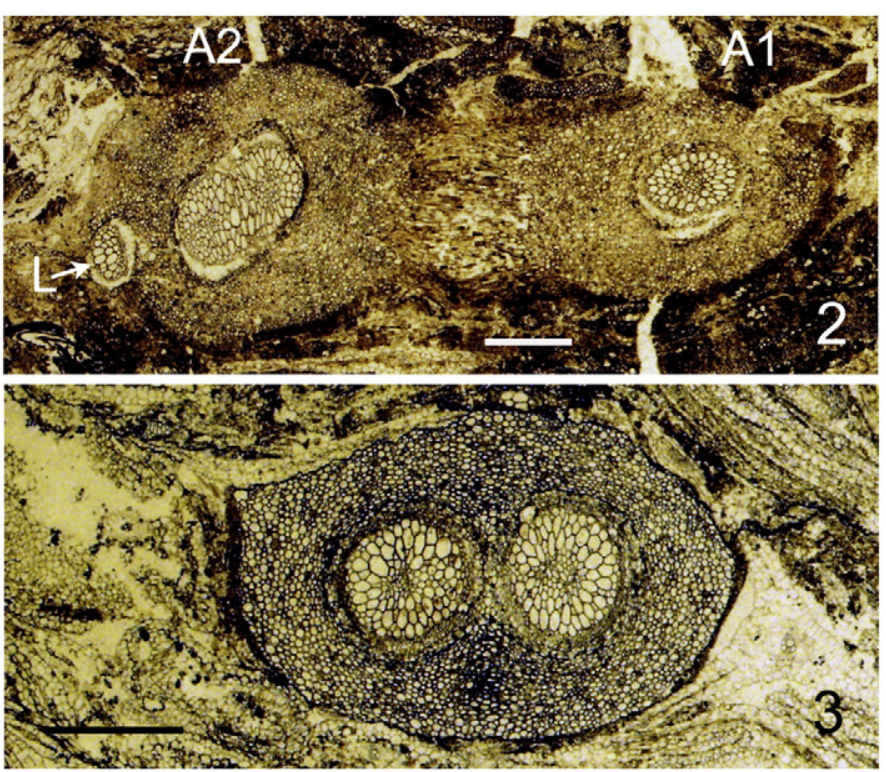

P.

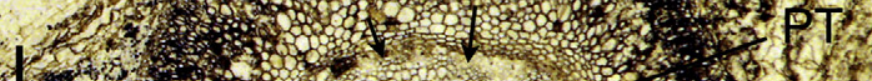
1.2

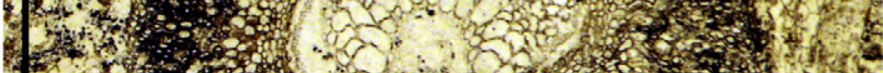

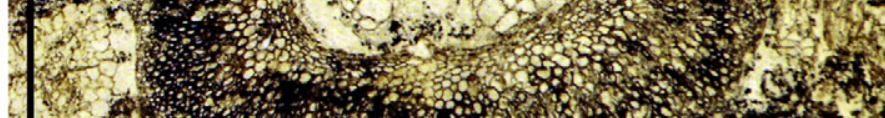

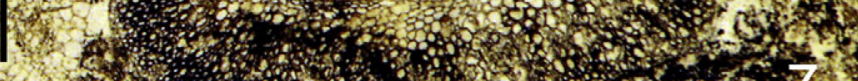

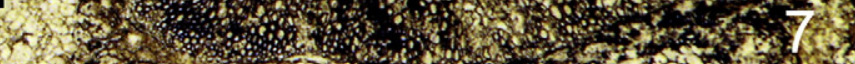

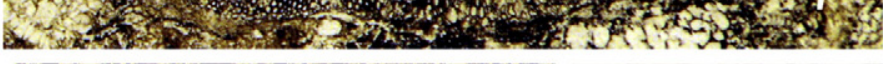

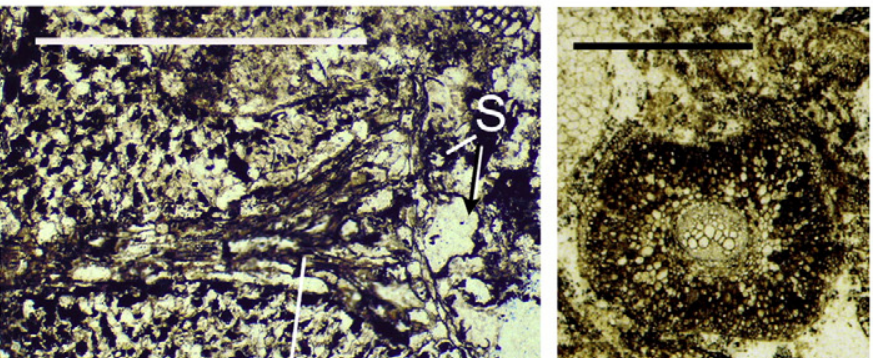

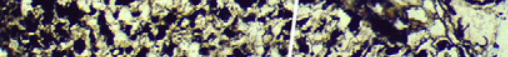

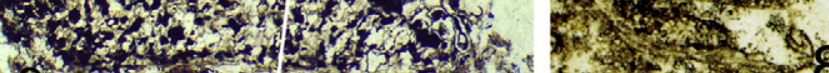

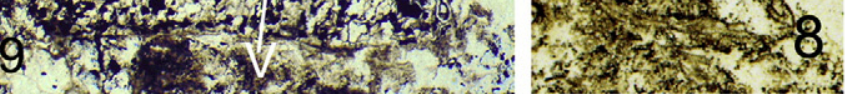

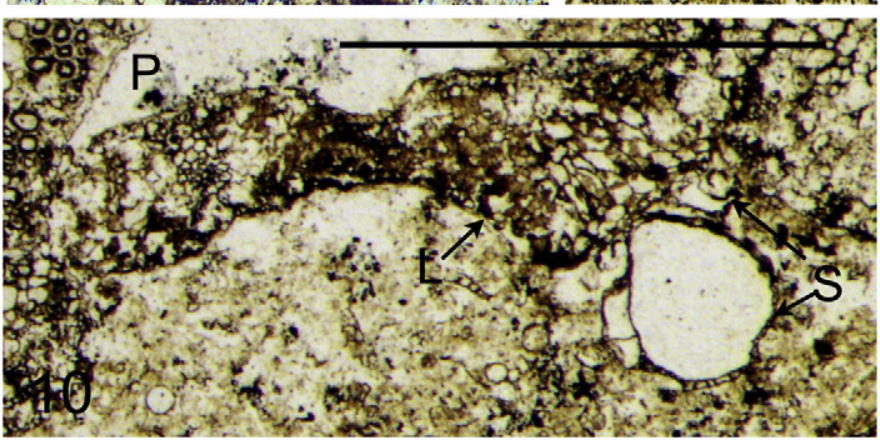


and smaller than in the previous examples; the departing leaf trace is massive and already C-shaped as schematized in Fig. 8H. There is a single leaf trace in the section of the stem (Plate XIV, 4) and the cortex is homogeneous, apparently devoid of scattered large cells, in the petiole. Roots are departing either from the protostele or from the petiole trace. A section of an attached petiole (Plate XIV, 8) shows an abundant ramentum and numerous roots, some connected to the petiole strand.

\subsubsection{Tubicaulis from the Late Pennsylvanian}

Tubicaulis stewartii Eggert (1959)from a Late Pennsylvanian coal ball of the Calhoun Coal, Illinois, was characterized as having an abundant xylem parenchyma, a lacunar middle cortex in both stem and petioles, a well developed integumentary system, and decurrent petiole bases with C-shaped xylem strand about $2 \mathrm{~mm}$ wide (Fig. 8K). Roots depart from the stele and basal portion of leaf traces. This species was considered as closely allied to Tubicaulis multiscalariformis, with similar features in stem cortex and leaf development; differences mainly concern the more abundant xylem parenchyma and lacunar cortex (not initially mentioned in T. multiscalariformis). No instance of the emission of pinna traces has been found.

The new material of American Tubicaulis, illustrated on Plate XIV, indicates that these Middle Pennsylvanian stems already exhibited many features (abundant xylem parenchyma, possible lacunar middle cortex, well developed ramentum, roots departing from both stele and leaf traces) first recognized in Tubicaulis stewartii.

Two Late Pennsylvanian Tubicaulis stems have been described from France (Galtier and Holmes, 1984) and both have been compared to Tubicaulis stewartii. One is an isolated stem with a subcircular protostele showing prominent radiating files of parenchyma cells. The second is an epiphyllous stem laterally borne on a rachis of Anachoropteris involuta (Fig. 8L) mentioned above (Section 3.2.2); the last stem, bearing nine petioles, was interpreted as conforming to the diagnosis of $T$. stewartii.

\subsubsection{Tubicaulis stem with "mixed pith" from the Permian}

Tubicaulis africanus Holden and Croft (1962) is the only species reported from Gondwana, with a probable Upper Permian age. The stem was described as upright, surrounded by a thick armor of persistent leaf bases; the cylindrical protostele has a central region (mixed pith) consisting of parenchyma intermixed with narrow tracheids. Leaf traces developed in close spiral succession, at first nearly circular in section then quickly developing abaxial curvature to slender C-shape (about $5 \mathrm{~mm}$ wide) distally where petioles are about $15 \mathrm{~mm}$ wide. Distal division of the petiole trace into three has been illustrated. Roots depart at and near the margins of petiole traces. Among the Tubicaulis with a parenchymatized protostele this species shows a number of unique features (protostele with a central mixed pith, leaf trace initially nearly cylindrical, petiole trace dividing into three distally, roots departing only from petiole traces, and thick mantle of leaf bases). To include this plant within Tubicaulis, despite these differences, Holden and Croft (1962) proposed an excessively enlarged range of the generic features. In fact, due to its Gondwanan origin and younger age, T. africanus may represent an isolated and divergent taxon.

In conclusion, the stems attributed to this second evolutionary line share a number of characteristics (see Fig. 8G-L) which are absent in Tubicaulis of the first evolutionary line. These are: 1) a parenchymatized protostele; 2 ) the xylem of the leaf trace is C-shaped very early, before trace departure; 3 ) a relatively large portion of the cauline xylem is involved in the leaf trace formation; 4) protoxylem groups of the leaf trace are unclear; 5 ) the petiole cortex shows a nest of sclerotic cells within abaxial xylem concavity; and 6) pinna traces have not been observed. Fig. 8 reveals clear differences in stele, leaf trace and petiole organization between the two evolutionary groups. As stated above (Section 4.1.3), the Tubicaulis with a solid protostele (Fig. 8A-E) are characterized by features which may be considered as generic. Therefore we consider that the use of the name of Tubicaulis for all these stems, including those corresponding to the second evolutionary line, is misleading.

\subsection{Interconnections between Tubicaulis and Anachoropteris}

Present data suggest that there is no proof of connections between Anachoropteris rachides/petioles and stems of Tubicaulis with a solid protostele (= Tubicaulis sensu stricto). Where known (Tubicaulis sutcliffi, Tubicaulis grandeuryi, Tubicaulis solenites) the C-shaped petiole xylem anatomy (curved adaxial median region extending to the lateral protoxylem strands and short arms) does not correspond to the characteristics of Anachoropteris as defined in this paper (Section 3.1) where the petiole xylem shows a rectilinear adaxial median region delimited by two prominent adaxial protoxylem strands and generally long arms.

In contrast, Tubicaulis stems with a parenchymatized protostele are the only ones eventually bearing Anachoropteris fronds. This was first demonstrated by Hall (1961) in one stem from Iowa showing the transition from "typical" Tubicaulis petiole to foliar anatomy of the Anachoropteris involuta type (Fig. 8I). This was confirmed by Phillips (1974), and in the present paper on several Middle Pennsylvanian stems from Illinois and Indiana. This transition from a small tubicaulid C-shaped strand to an inrolled xylem corresponds to a more distal region of some attached petioles. However, the transition to large petioles with a typically involuted-revoluted xylem has not yet been established as indicated by the comparison of the largest inrolled petiole (Fig. 8I) with the typical A. involuta rachis (at right in Fig. 8L).

Another type of interconnection is now established: epiphyllous shoots occurring on some Anachoropteris fronds correspond also to Tubicaulis-type of stems with parenchymatized protosteles; this is known from the Early Pennsylvanian, in shoots borne on Anachoropteris williamsonii (Fig. 8F), and from the Late Pennsylvanian in shoots borne on Anachoropteris involuta, first mentioned by Hall (1961), and described in more detail by Galtier and Holmes (1984) (Fig. 8L). In fact, these proved connections raised a nomenclatural problem; Hall (1961) did not describe a new species of Tubicaulis for the stem bearing petioles showing transition to involute Anachoropteris type, suggesting implicitly that the name of $A$. involuta could be used for this plant.

In fact, it must be noted that most epiphyllous shoots borne by Anachoropteris rachides are not of the Tubicaulis-type. Epiphyllous stems borne on Anachoropteris gillotii (Section 3.4; Plate VIII) and Anachoropteris robusta (Section 3.5; Plate IX), like those of Kaplanopteris clavata (Section 3.7; Plate X), have solid protosteles but these are small and more similar to botryopterid-type protosteles. This has been already suggested by Morgan and Delevoryas (1954) who emphasized the differences between Tubicaulis and these smaller taxa (Anachoropteris clavata, Apotropteris) where a large portion of the stele separates as a leaf trace. Lastly, we have to mention the adaxial shoots borne on Middle Pennsylvanian involute Anachoropteris (Section 3.2.3; Plates III-V) which are either protostelic or siphonostelic but not really conforming to the Tubicaulis type.

\subsection{Ecology of Anachoropteris and Tubicaulis}

Anachoropteris is well known from coal-ball peats; however, with the notable exceptions of Anachoropteris williamsonii, Anachoropteris clavata and Anachoropteris involuta, the majority of the described species are associated with clastic, if not volcaniclastic, substrates. This is the case of the type material of Anachoropteris radnicensis and of Anachoropteris pulchra (Middle Pennsylvanian, Czech Republic) and of other specimens attributed to the last species from the Late Pennsylvanian of France and the Early Permian of Germany and Sardinia. Similarly, the types of material of Anachoropteris gillotii, Anachoropteris pautetii, Anachoropteris robusta (Late Pennsylvanian, France), and Anachoropteris circularis, Anachoropteris gigas, and Anachoropteris ovata (Early Permian, France) come from non-coal swamp environments. This overrepresentation certainly does not reflect the real diversity but is partly 
the result of "splitter" systematic studies of European material. However, it is significant that we now recognize representatives of all four main "anachoropterid groups" (numbered as B to E in Fig. 1) in the older European coal-ball peats of Early Pennsylvanian time. We previously noted that the largest size within the "pulchra-involuta" and the "robusta" groups was recorded for younger taxa from clastic substrates; this acquisition of a robust stature may reflect higher nutrient environments than those of coal swamps.

In some of the oldest Early Pennsylvanian coal-ball floras from Europe small ferns (zygopterids, ankyropterids, anachoropterids and botryopterids) are a common component, occurring on a frequency basis of $25 \%$ in the Bouxharmont coal balls of Belgium and $28 \%$ in those of the Union seam of England. Anachoropterids (including Anachoropteris and Psalixochlaena) occur in about 6\% of the coal balls with Anachoropteris more common in the Bouxharmont (Holmes and Fairon-Demaret, 1984). However, quantitative analyses of these coal balls indicate that these ferns were minor biomass contributors and a similar pattern is found in coal beds throughout the Pennsylvanian of North America (Phillips et al., 1985; DiMichele and Phillips, 2002).

All the Tubicaulis specimens with a parenchymatized protostele (Fig. 8F-K) come from coal-ball peats with the notable exceptions of the much younger Tubicaulis africanus which has divergent characteristics, and of one Tubicaulis shoot, identified as Tubicaulis stewartii (Fig. 8L), laterally borne on Tubicaulis involuta rachis from cherts of the Late Pennsylvanian of France. In contrast, the majority of Tubicaulis with a solid protostele (Fig. 8C-E) come from clastic environments, and this is probably also the case of Tubicaulis sutcliffii (Fig. 8A) found in a roof nodule. The only exception is Tubicaulis scandens (Fig. 8B) from a Late Pennsylvanian coal ball. The occurrence of a lacunar cortex in the stems and petioles of the Late Pennsylvanian T. stewartii (Eggert, 1959) and the Early Pennsylvanian Tubicaulis sp. from England (Plate VII, 7) may be interpreted as adaptation to the wet coal-swamp environment. In contrast, the ecological significance of dispersed large cells, often with thickened walls, in the cortex of several Tubicaulis (Plate XIII, 4, 9, 16; Plate XIV, 6) remains unclear.

\subsection{Habits of Anachoropteris and Tubicaulis}

Different growth architectures corresponding to different categories of branching have been recognized in small Paleozoic ferns (Galtier and Holmes, 1982; DiMichele and Phillips, 2002) allowing them to acquire a variety of habits. We previously summarized (Phillips and Galtier, 2005,2011 ) the very distinct habits observed in the zygopterid and ankyropterid ferns.

It is likely that the involute Anachoropteris foliar members were borne on Tubicaulis-like stems (Hall, 1961; Phillips, 1974) which were semi erect to erect and rarely branched. The fronds, in turn, played an important role in vegetative propagation with adventitious shoots developed on several orders of foliar members.

With the exception of Tubicaulis africanus, all the Tubicaulis with parenchymatized protostele correspond to relatively short (known length up to $6 \mathrm{~cm}$ ), unbranched stems with short internodes and bearing small petioles. They are covered with roots, sometimes departing also from the petiole bases, and they are sometimes designated as rhizomes. Eggert (1959) considered that Tubicaulis stewartii had an upright stem with determinate growth; while Hall (1961) considered that the Tubicaulis shoot was erect, possibly subterranean, and at least several $\mathrm{cm}$ long. We agree with this interpretation which applies also to several un-named Tubicaulis shoots borne on long scrambling Anachoropteris frond rachides as discussed above. In this case, the Tubicaulis stem is a small part of a sort of clonal system of which the scrambling rachides are the dominant part.

Holmes (1989) recapitulated all known positions of shoots borne on fronds, including the trifurcation of the rachis to give a median stem, so far only known to occur in the genus Anachoropteris. In the present paper, we document the occurrence of epiphyllous shoots in the four main anachoropterid groups. The petioles of Anachoropteris clavata were first interpreted (Delevoryas and Morgan, 1954) as having functioned as stolons giving rise to new shoots. Hall (1961) suggested that Anachoropteris petioles were attached to an "embryonically derived primary axis (Tubicaulis) erect or subterranean", of probable determinate growth. The extremely long petioles were a more conspicuous part of the plant than the stem; they were of indeterminate growth, scrambling, and, in turn, they were bearing shoots.

This is not contradicted by the new interpretation of the growth architecture of Kaplanopteris (Anachoropteris) clavata with two types of reiterative units (Tomescu et al., 2006, 2008); the authors proposed that short orthotropic epiphyllous plantlets produced fronds with indeterminate growth and scrambling or climbing habit, while frond rachides also bore latent crosiers of arrested fronds. It has been suggested that many species of Anachoropteris were much like modern "walking ferns" that produce stem buds on scrambling frond rachides enabling them to spread rapidly across open substrate (DiMichele and Phillips, 2002). As documented in the present paper, this type of habit occurs in the Early Pennsylvanian Anachoropteris williamsonii and Anachoropteris gillotii, in several unnamed American Middle Pennsylvanian involute Anachoropteris species with adaxial shoots, and in the Late Pennsylvanian Anachoropteris involuta and Anachoropteris robusta and the Early Permian Anachoropteris circularis.

In addition to scrambling habit, adaptations to climbing also exist in several species showing recurved secondary pinna rachides arching over the adaxial side of the main rachis. This was first described by Corsin (1937) as "aphlebiae" in Anachoropteris involuta, but this feature is also present in some American involute Anachoropteris (Plate III, 3, reconstructed in Fig. 3), in Anachoropteris williamsonii (Plate VI, 1) and in Anachoropteris circularis (Plate IX, 11). The occurrence of A. involuta rachis at the periphery of Psaronius root mantle (Galtier, 2008) and furthermore, of Anachoropteris pulchra rachides found inside the root mantle of Psaronius from the Early Permian of Germany (Rössler, 2000) and France (JG personal observation), are direct evidence of epiphytic, or more precisely, of a hemi-epiphytic habit for these plants.

Finally, it is worth mentioning the new American Middle Pennsylvanian fertile pinnae associated with foliar members bearing adaxial shoots (cf. Section 3.2.3) which could have aided further propagation in climbing. It is tempting to suggest that such upward facing sori (perhaps the largest branching receptacle recorded) without indusia invites wind, rain drops or crawling visitors to aid in dispersal. Furthermore, the specimens have abbreviated succulent laminae consistent with avoiding water loss and also consistent with structural strength and water storage. As a reasonable alternative, if the fertile material is displayed adaxially by a fern with scrambling fronds, the face up would certainly be better for spore dispersal over a prolonged interval as well as avoiding quick burial by litter if abaxial. Also, in a swamp, the adaxial fertile pinna position would help avoid submergence in water.

The contrasting sizes within Tubicaulis stems have been emphasized (Galtier and Phillips, 1996, Fig. 6) and correlated with differences in habit. Unbranched erect stems of Tubicaulis sutcliffii and Tubicaulis solenites, with a thick mantle (about $10 \mathrm{~cm}$ in diameter) of large petiole bases and roots, are characteristic of an upright habit. While these two species had a solid protostele, the same upright habit also characterized Tubicaulis africanus, the youngest member of the second evolutionary line (with parenchymatized protosteles). These plants probably had the habit of small tree-ferns with very large leaves of which the distal part is unknown. These fronds, probably not conforming to the Anachoropteris-type anatomy, were bearing precocious, "aphlebia-like" pinnae. The occurrence of these precocious branched pinnae is interpreted as a convergence with the similar pinnae/"aphlebiae" occurring also on the basal region of petioles of the zygopterids, Symplocopteris and Zygopteris primaria, and of the ankyropterid, Anachoropteris hendricksii, which have also an erect-stem habit. A protective role for developing frond primordia is suggested for these organs. 
Branching of the axillary-type was described in Tubicaulis grandeuryi (Galtier and Holmes, 1984) but it also occurs in stems from Germany which are clearly epiphytes on Psaronius (Rössler, 2000). The American Tubicaulis scandens, another stem with a solid protostele and with long internodes, has been documented as an epiphyte of Psaronius (Mamay, 1952 ) and the same habit was suggested, but not demonstrated, for Tubicaulis berthieri.

\section{Psalixochlaena cylindrica and the Psalixochlaenaceae}

Psalixochlaena cylindrica (Will.) Holden is one of the most completely known Carboniferous ferns as a result of extensive studies by Holmes (1977, 1981a,b, 1989). This plant was first described by Williamson (1878) from coal balls of the Halifax Hard Bed (Yorkshire) under the name of Rachiopteris cylindrica. Bancroft (1915) retained this generic name but, subsequently, several authors (e.g. Scott, 1920; Leclercq, 1925 ) attributed the plant to the genus Botryopteris. Later, Holden (1960) referred it to a new genus, Psalixochlaena and, recognizing the abaxial curvature of the foliar xylem, he suggested the inclusion of P. cylindrica in the Anachoropteridaceae. Another species, Psalixochlaena berwickense Long (1976) from the Mississippian of Scotland, has a similar cauline anatomy but shows lateral trifurcations and no evidence of a megaphyllous leaf; this plant does not fit with the new generic diagnosis proposed by Holmes (1981a), and it is not taken in consideration in the present review.

Psalixochlaena cylindrica has long been considered as restricted, geographically and stratigraphically, to Early Pennsylvanian (basalmost Langsettian/Westphalian A) coal balls of England (Halifax Hard Bed, Yorkshire and Union Seam, Lancashire) and Belgium (Bouxharmont) but, more recently, it has been recognized in contemporaneous coal balls of Truebano, Spain (Beckary, 1988) and of New Castle Coal Bed, Walker County, Alabama, U.S.A. (Winston and Phillips, 1991). This fern is rare, occuring in about $5 \%$ of 1000 coal balls examined from the Union Seam of Lancashire, and in less than $2 \%$ of 500 coal balls from Bouxharmont (Holmes and Fairon-Demaret, 1984).

\subsection{Structure and development of the cauline system}

Holmes (1977) collected large amounts of new British material of Psalixochlaena cylindrica, with the objective of reconstructing long and highly ramified specimens, and determining the position of leaves, lateral branches and dichotomies. Some specimens have been entirely serially sectioned, their individual reconstruction necessitating several thousand peels. The quantity of observations accumulated has permitted an ontogenetic approach to the interpretation of the growth of the plant without equivalent in other small Carboniferous ferns. Stems are long and slender, 2-2.5 $\mathrm{mm}$ in width, with a terete mesarch solid protostelic xylem, up to $0.9 \mathrm{~mm}$ in diameter (Plate XV, 1-3). Three types of stelar division are observed: i) isotomous dichotomy, ii) lateral emission of a common trace which divides into a leaf trace and an axillary or epipetiolar branch trace, and iii) leaf trace emission. As reconstructed in Fig. 9, three orders of branches have been found: main axes (A) with long (4 to $11 \mathrm{~cm}$ ) internodes, second order branches (B) with shorter but highly variable internodes and finally third order branches (C), either in a bud-like state or short and bearing one to three leaves. The lateral system, composed of a branch with its axillant leaf (Plate XV, 4 ), is the main form of branching in all orders of axes giving rise to a predominantly monopodial branching system. Very occasionally two successive branches occur in the axil of the same leaf (=double lateral system, Plate XV, 5-6; B3, Fig. 9). The isotomous dichotomy occurs sporadically; it is occasionally isolated (Plate $\mathrm{XV}, 3$ ) but more commonly in close association with a lateral branch involving a trifurcation of the stele (Plate XV, 2).

Holmes (1977) demonstrated considerable variation in the ontogeny of second order branches of Psalixochlaena cylindrica. Either they have a wide stele at the base with lateral systems at long internodes (B1, Fig. 9), or they initially bear two or three closely spaced leaves, then leaves with axillary buds (B2, Fig. 9); in the latter case the branch xylem shows a marked obconical (epidogenetic) development and rapidly reaches similar dimensions to that of the parent axis. Inversely, axes of all orders show distal tapering steles (apoxogenetic growth) towards apical regions which are exquisitely preserved. The structure of the

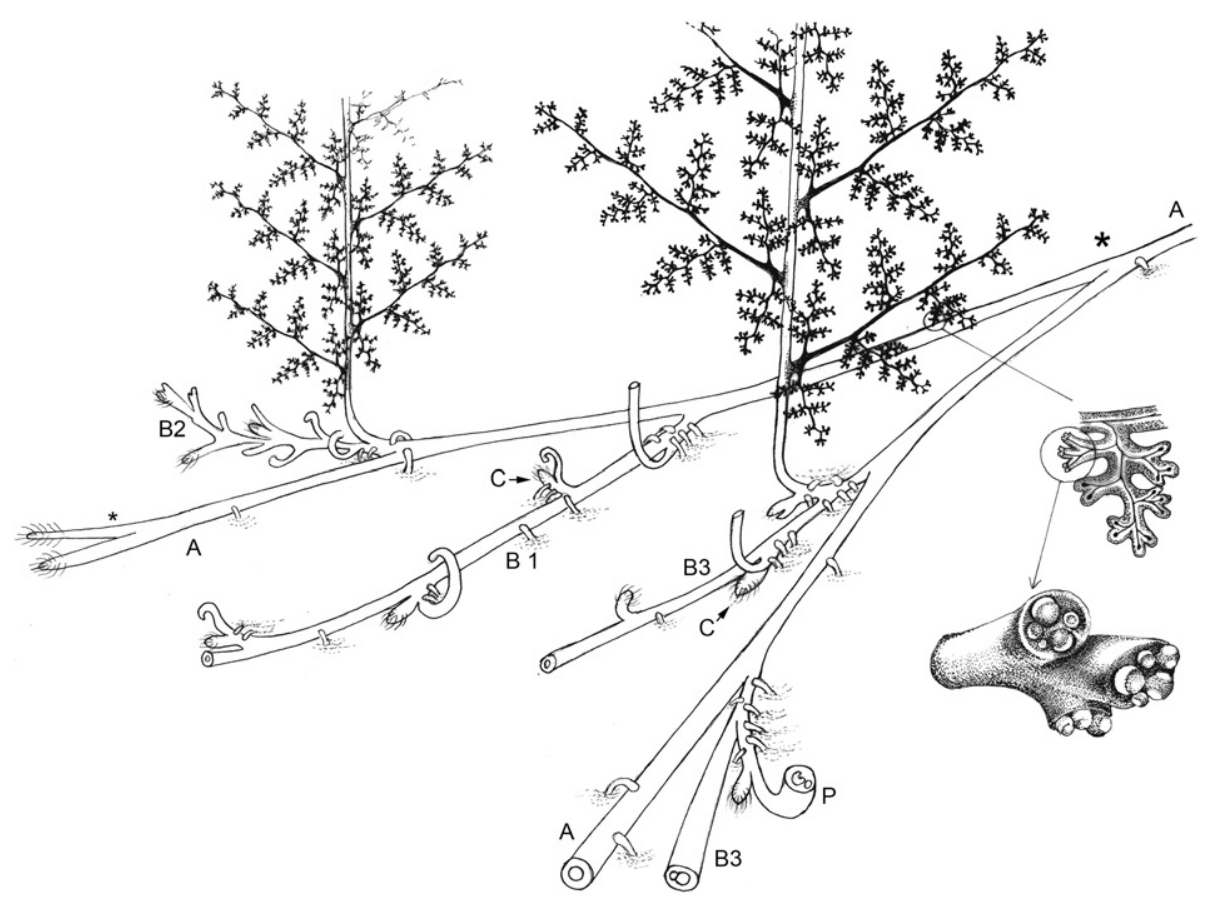

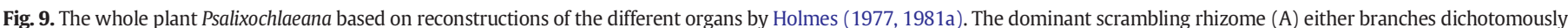

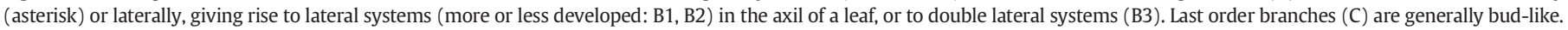

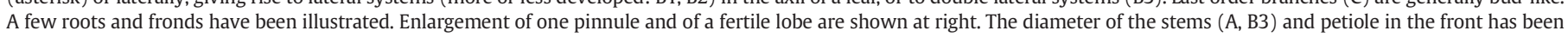
exaggerated to show anatomy. 
lateral system of this fern is similar to some types of ramifications existing within the present Hymenophyllaceae and Stromatopteridaceae (Bierhorst, 1974).

The sturdy development of some of the lateral branches suggests that the so-called main axes may be the median or distal parts of lateral branches and that this fern, like the extant Pteridium aquilinum (Webster and Steeves, 1958; Dasanayake, 1960), showed a repetitive growth habit where laterals eventually took over the role of main axes. Measurements of metaxylem tracheid lengths in short leafy and long internoded laterals, as well as the occurrence of very long phloem elements in long stems, support the idea of increased growth rate in more distal regions of Psalixochlaena cylindrica stems. With the possibility of conversion from leaves to lateral systems at the base of branches, $P$. cylindrica represents the oldest known evidence of a capacity for changeover from one type of apical functioning to another. It is also one of the oldest examples of an axillary lateral branch associated with a true frond. In the contemporaneous Ankyropteris brongniartii the axillant leaf is of phyllophore-type. Finally, Holmes (1989) emphasized the considerable range of branching types occuring in P. cylindrica, including one exceptional example of adaxial epiphyllous shoot. Psalixochlaena cylindrica, with its highly branched cauline system, strongly contrasts with most of the anachoropterid ferns considered in this paper where cauline structures are rarely branched and short by comparison, but with common occurrences of epiphyllous shoots.

\subsection{The frond and fertile parts}

The frond of Psalixochlaena cylindrica has been reconstructed from serial peel sections (Holmes, 1981a). The main rachides have been identified by comparison with petioles (up to $8 \mathrm{~cm}$ long) attached to stems. The petioles, up to $2 \times 2.5 \mathrm{~mm}$ in diameter, are axillant to a branch or closely spaced in a $2 / 5$ phyllotaxis; they are circinately coiled when young. The petiole xylem basally oval (LT, Plate XV, 4) is changing upward to C-shape, up to $0.9 \mathrm{~mm}$ wide. The main rachis xylem shows two persistent protoxylem poles (median arrows, Plate XV, 7) and two lateral ones, that represents a typical anachoropterid foliar anatomy (compare to Plate I). Primary pinnae, up $9 \mathrm{~cm}$ long, are departing alternately at 1 to $3 \mathrm{~cm}$ intervals; their rachides, up to $1.4 \mathrm{~mm}$ wide, have a xylem strand $0.3 \mathrm{~mm}$ wide with slight abaxial curvature (Plate XV, 8); like the main rachides they show a marked adaxial groove. They bear alternately up to ten secondary pinnae, at least $3 \mathrm{~cm}$ long, with a flexuous rachis (SPR, Plate XV, 11) possessing an enveloping layer of spongy tissue.

Pinnules are triangular, up to $10 \mathrm{~mm}$ long, and composed of multilobed segments corresponding to sphenopterid-type foliage ( $P$, Plate $\mathrm{XV}, 11$ and Fig. 9, at right) with narrow finely divided lobes, $0.5 \mathrm{~mm}$ wide, with rounded apices. Pinnule veins with a parenchyma sheath terminate in a pyriform swelling (Plate XV, 10); they are surrounded by a spongy tissue which extends down to the outer cortical layer of pinnae rachides. Sparsely occuring fertile lobes, are possibly restricted to basal pinnules. Fertile lobes are truncated with a swollen vascular strand $(\mathrm{V}$, Plate $\mathrm{XV}, 9)$ terminating beneath the soral receptacle. The circular soral receptacle is inclined towards the abaxial side (Plate XV, 10). Gradate sori are composed of five annulate sporangia. Most observed sporangia were immature, pyriform, $300 \mu \mathrm{m}$ long with a bi-triseriate oblique annulus and a vertical zone of dehiscence (S, Plate $\mathrm{XV}, 10)$.

The frond, about $30 \mathrm{~cm}$ long and $15 \mathrm{~cm}$ wide, has been reconstructed by Holmes (1981a) as planated, tripinnate and catadromic with subopposite insertion of basal secondary pinnae and pinnules (Fig. 9). This frond resembles a number of Late Carboniferous compression-impression fossils showing delicate pinnules with annulate sporangia situated at lobe endings. The most comparable are Hymenophyllites (Brousmiche, 1983), Boweria minor (Kidston, 1923) and Sphenopteris sp. (Leary, 1979) which all correspond to sphenopterid foliage with a much reduced webbing representing the simplest type of laminate pinnule. However, Psalixochleana cylindrica does not seem to correspond exactly, in all its characters, to any of the above mentioned ferns.

\subsection{The Psalixochlaenaceae}

Psalixochlaena cylindrica was previously assigned to the coenopterid Anachoropteridaceae but, following the description of its frond and fertile characteristics (terminal circular soral receptacle and gradate sori of five annulate sporangia), it was made the type genus of the new family Psalixochlaenaceae within the Filicales (Holmes (1981a). Psalixochlaena cylindrica is also distinguished from the other anachoropterid ferns by its mesarch protostelic stems which are extensively branched, either dichotomously or laterally. It has been emphasized that this fern shows important similarities to the extant Hymenophyllaceae in the structure of their lateral branching systems and of their marginal and gradate sori. The Sermayaceae (Eggert and Delevoryas, 1967) was, before the Psalixochlaenaceae, the first anachoropterid family segregated on the basis of fertile characteristics, as was more recently the Kaplanopteridaceae (Tomescu et al., 2006). Despite similar sporangia, the Sermayaceae differ from the Psalixochlaenaceae in their superficial sori, in addition to differences concerning cauline and foliar anatomy and morphology. The Kaplanopteridaceae are distinct by the possession of conical indusiate soral receptacle and small sporangia with long stalks, in addition to differences concerning cauline and foliar anatomy and morphology.

\subsection{Ecology and habit}

Psalixochlaena cylindrica is only known from coal-ball peats. As reconstructed in Fig. 9, this fern, with slender stems and long internodes, growing singly or in dense mats, was probably rampant along the swamp surface or slightly subterranean in the manner of some Hymenophyllaceae. According to Holmes (1981a) stems have never been observed penetrating any other organ, however some stems have been found sandwiched between layers of lycopod bark (Plate $X V, 1$ ), as if they had grown through a hollow log lying on the surface. Buds and developed branches always lie parallel to the parent stem and support the idea of the propagation of a horizontal system. Holmes (1977) suggested that stem branching appears admirably suited to colonization of peat swamps. Dichotomous branching ensures vegetative propagation as does lateral branching but, more importantly, the latter provides a continuity of growth through time by a relay of axes which solve the problem of apical senescence or damage. Perhaps also buds of both delayed and immediate development offer the possibility of surviving adverse conditions in the dormant state. While stem and apices of $P$. cylindrica are often very well preserved, petioles become decayed over a short distance and distal frond portions are very rare. This is in agreement with the suggested habit of rampant stems bearing erect fronds; later the old fronds decayed leaving only short petiole/rachis bases attached to stems. In conclusion, this specialized habit is different from those described above in the other anachoropterids which show either dominant scrambling fronds with epiphyllous shoots, or erect stems either massive or epiphytic.

\section{Apotropteris minuta}

Apotropteris minuta is known only from the Late Pennsylvanian of the U.S.A. This small fern was originally described by Morgan and Delevoryas (1954) from a coal ball in the Opdyke Coal in the McLeansboro Group, near Dix, Illinois (Phillips, 1980). The original specimen consists of a slender stem (3.8 $\mathrm{mm}$ in diameter) bearing petioles and adventitious roots. The protostele, about $1 \mathrm{~mm}$ across, was described as solid with one central group of protoxylem and small groups of tracheids around the circumference of the xylem interpreted as peripheral protoxylem. Metaxylem tracheids have multiseriate scalariform thickenings. Petioles arise from stem in no definite sequence. The authors emphasized 
the fact that the departing petiole trace is almost equal to the stele in cross-sectional area, leaving the stele with a V-shaped depression on the side adjacent to the departing petiole strand. Some of the once central cauline protoxylem tracheids continue along the adaxial surface of the petiole trace. A short distance above its point of origin, the petiole trace assumes an inverted C-shape with abaxial expanded arms; the protoxylem is usually in four groups on the adaxial side of the petiole xylem.

Additional information has been provided by Phillips (1974) from material from Berryville. Somewhat larger specimens have a small pith and leaf gaps. This is illustrated on the successive sections of one excellently preserved stem. One departing petiole trace is at first oval and as broad as the diameter of the cauline stele which shows a typical leaf gap (Plate XVI, 1). Higher up the leaf gap is not yet closed and the cauline xylem shows an indentation (Plate XVI, 2), corresponding to the V-shaped depression originally reported by Morgan and Delevoryas (1954); at this level the petiole trace (P, Plate XVI, 2) is within the stem cortex and shows abaxially expanded arms and several adaxial protoxylem strands. Root traces are sparsely arising from the stem. The illustrated specimen (Plate XVI, 3-4) suggests evidence of branching; however, the stem was bent double, not dichotomous.

It has been suggested (Stewart and Rothwell, 1993) that Apotropteris may represent a fragment of the distal portion of a plant similar to Psalixochlaena. Actually, both possess one central protoxylem strand in the cauline stele but they differ by the occurrence, in Apotropteris, of peripheral protoxylem strands that are not present in Psalixochlaena. However, considering that only the central protoxylem is involved in petiole trace emission, we interpret as very doubtful the protoxylem nature of the small peripheral tracheids of Apotropteris. Furthermore, both taxa possess very similar small C-shaped petiole traces (compare Plate XV, 7 and Plate XVI, 2) which are distinct from those of other anachoropterids, including the small Kaplanopteris (Plate X, 2) where the abaxial petiole xylem arms are longer and more expanded.

Apotropteris and Psalixochlaena appear more similar to each other than to other anachoropterids; despite a significantly different age, these two coal-swamp plants may belong to the same evolutionary trend within the anachoropterid ferns. Additional information on the vegetative morphology and reproductive structures of Apotropteris are needed to confirm or not its relationships with the genus Psalixochlaena as reconstructed by Holmes (1977, 1981a) and reported above.

\section{Grammatopteris}

Grammatopteris is a genus of anatomically preserved ferns originally described from the Early Permian of Europe. Grammatopteris was instituted by Renault (1891) to accommodate Grammatopteris rigollotii from the Early Permian of Autun, France. The specimen consisted of one stem with a solid protostele and spiral arrangement of bar-shaped petiole xylem strands without any curvature, therefore distinct from Tubicaulis. Later, a specimen found in the Early Permian petrified forest of Chemnitz, Germany, was described as Protothamnopteris baldaufii (Beck, 1920); it was transferred to the genus Grammatopteris by Hirmer (1927), and subsequently studied in detail by Sahni (1932a). Corsin (1937) reinvestigated G. rigollotii type material and introduced a new species, Grammatopteris bertrandii, for isolated petioles of grammatopterid type from the Early Carboniferous (Late Viséan) of Esnost, near Autun, France. Recently, the geographic distribution and our understanding of the genus were significantly extended following the discovery of Grammatopteris freitasii from the Permian of Brazil (Rössler and Galtier, 2002).

\subsection{Grammatopteris rigollotii, the type species}

The type species Grammatopteris rigollotii was initially described by Renault (1891, 1893-1896) from polished surfaces of two silicified specimens but Corsin (1937) obtained the preparation of one transverse

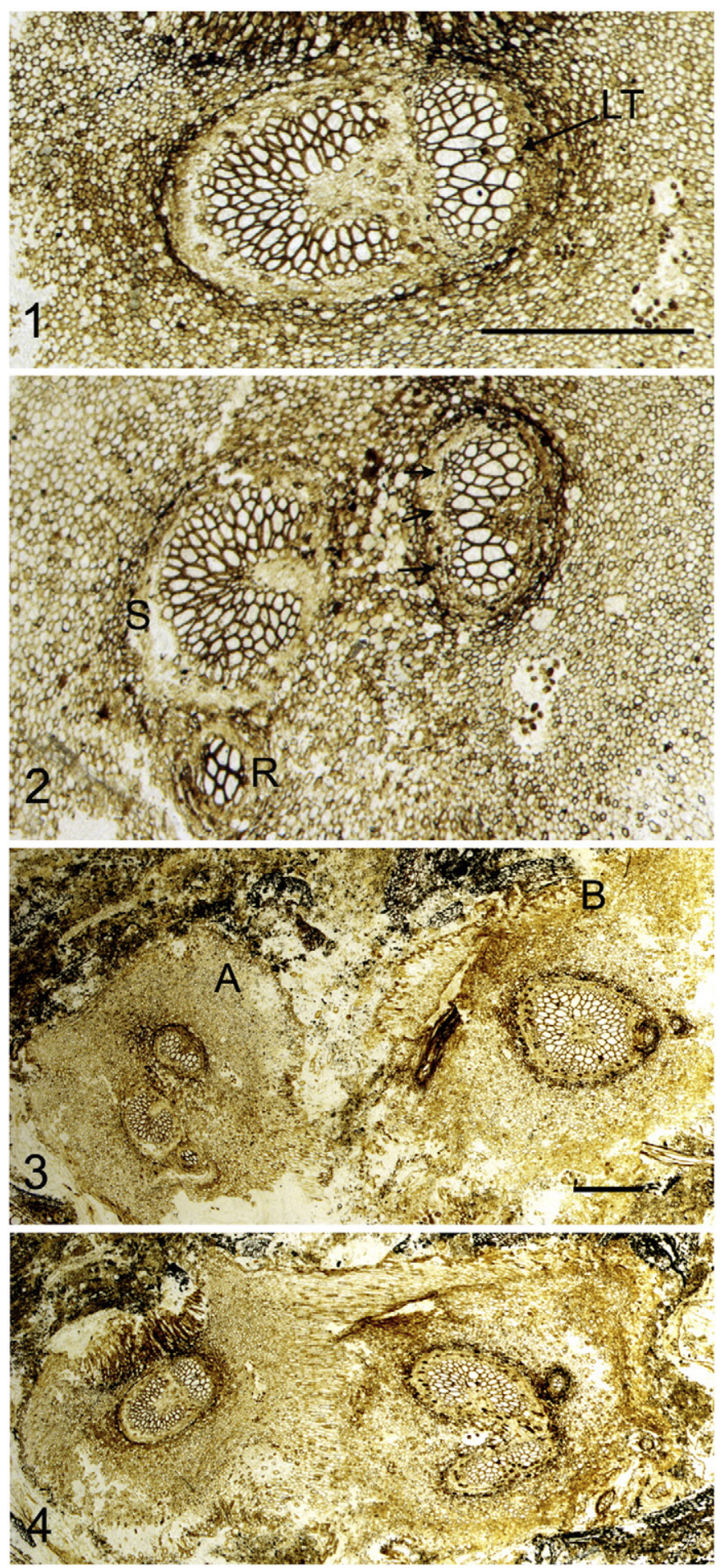

Plate XVI. Apotropteris minuta, transverse sections of a curved cauline system. All from Calhoun Coal, Berryville, Illinois, Late Pennsylvanian. Scale bars $=1 \mathrm{~mm}$.

Siphonostelic stem with leaf gap and bar-shaped leaf trace (IT). UI13769B134.

2. More distal section of the same showing the stele (S) with central protoxylem, decurrent leaf gap not yet closed, the leaf trace becoming abaxially curved with three adaxial protoxylem strands (arrows), and a departing root trace (R). UI13769B-198.

3. General view of the cauline system curved and twice sectioned. The stem (A) at left is shown in detail in 2; the stem B possesses a very small central pith. UI13769B-198.

4. Section near the level of stem bending. The stem, at left, is shown in detail in 1. UI13769B-134 
ground-thin section which allowed him to accurately describe cortical tissues, leaf traces and phyllotaxis. This slide is illustrated on Plate XVII, Fig. 1; it shows the central solid protostele (S), about $5 \mathrm{~mm}$ in diameter, decurrent bases of petioles and roots surrounding the stem; the overall diameter being about $8 \times 4 \mathrm{~cm}$. The parenchymatous inner cortex of the stem (IC, Plate XVII, 2) contains a large number of barshaped departing leaf traces, and it is well delimited from the middle cortex. A new interpretation of this section (Galtier et al., 2001, Fig. 21) suggested that the mantle of free roots and petioles was much narrower than indicated by Corsin (1937, Fig. 1). Furthermore, it was established that the "ramentum" structures correspond to roots showing a horizontal course within the stem cortex (r, Plate XVII, 1); however, information on the origin of root traces (from the cauline stele or from the leaf trace) is missing.

As well illustrated by Corsin, the solid protostele is exarch; the leaf trace is initially oval, then quickly bar-shaped, $1.5 \mathrm{~mm} \times 0.5 \mathrm{~mm}$, with two lateral and adaxially situated protoxylem strands (arrows, Plate XVII, 3). Higher up the leaf trace enlarges tangentially to more than $3 \mathrm{~mm}$ (Plate XVII, 4) while free petioles are about $10 \mathrm{~mm}$ in diameter. There is evidence of division of lateral proxylem strands (Galtier et al., 2001 , figs. 25, 30E-F) but the emission of either pinna trace or pinna has not been observed.

\subsection{Grammatopteris baldaufii}

Following the detailed study by Sahni (1932a) and additional observations by Rössler and Galtier (2002), Grammatopteris baldaufii is known as a small trunk with a basal root-felt up to $8 \mathrm{~cm}$ in total diameter. The stem diameter with decurrent petioles being about $40 \mathrm{~mm}$ and the stele is 4 to $5 \mathrm{~mm}$ in diameter; therefore, this species is very similar in size to Grammatopteris rigollotii. In both cases there is a solid protostele and petiole trace is bar-shaped with two adaxial protoxylem strands. However, in G. baldaufii the outer cauline xylem shows peripheral invaginations, small tracheids are scattered within the central xylem as well as short "parenchymatic tracheids", and clusters of sclerotic cells occur in the middle cortex; finally, root traces are derived from the abaxial side of the leaf trace. All these features, illustrated in Rössler and Galtier (2002, Plate VII), are unknown in G. rigollotii. Other differences concern phyllotaxis (5/13 in G. baldaufii instead of 2/9 in G. rigollotii) and the slightly smaller size of petiole and petiole trace in G. baldaufii.

\subsection{Grammatopteris freitasii}

This species comes from the Pedra de Fogo Formation in the State of Tocantins, NE Brazil; the geological setting and Permian age of this sedimentary sequence have been discussed in detail in Rössler and Noll (2002). The new taxon Grammatopteris freitasii (Rössler and Galtier,
2002) was based on exceptional material consisting of 16 different specimens of stems, ranging from 4 to $35 \mathrm{~cm}$ in diameter, and representing different positions along the stem. The basal region shows a narrow central stem (3-4 cm in diameter) completely clothed in a mantle of adventitious aerial roots up to $32 \mathrm{~cm}$ in thickness, as illustrated by Rössler and Galtier (2002, Plate III, 1). In contrast, in the distalmost region, the periphery of the stem shows free petiole bases and interspersed roots. Fragments from the middle to upper part of the plant are illustrated on Plate XVII, figs. 5-8. These two paratype specimens are very instructive, providing excellent information on the solid protostele ( 4 to $9 \mathrm{~mm}$ in diameter), on the leaf-trace emission with $5 / 13$ phyllotaxis (Plate XVII, 6), and on the root-trace emission from the proximal abaxial side of leaf traces (RT, Plate XVII, 7).

Free petioles (P, Plate XVII, 5, 8) are subtriangular in transverse section and up to $20 \mathrm{~mm}$ in diameter. The leaf trace is at first elliptical but finally the petiole xylem strand is in the form of a tangentially elongated bar (up to $1 \times 10 \mathrm{~mm}$ ) with two marginally adaxial protoxylem strands. The petiole shows a strong sclerenchymatous outer cortex. Subopposite pinnae, $3.5 \mathrm{~mm}$ in diameter basally, are borne in the very proximal region of the petioles; their small circular traces (arrows, Plate XVII, 8 ) are detached from the lateral margin of the petiole xylem strand and become slightly C-shaped in the free pinna. Roots are diarch, up to $5 \mathrm{~mm}$ in diameter, and with an exclusively downward course.

Grammatopteris freitasii presents a number of conspicuous features not visible (or not known) in the other species, which justified its separation but also significantly completed the generic diagnosis. Knowledge of its ontogenetic variability allowed Rössler and Galtier (2002, Fig. 6) to reconstruct this species as a tree fern with a trunk up to $40 \mathrm{~cm}$ in diameter and probably several meters in height.

\subsection{The enigmatic Grammatopteris bertrandii}

The original material of this taxon was a chert specimen, from the Early Carboniferous (Late Mississippian) of Esnost near Autun, containing about twenty rachides lying parallel to each other. Corsin (1937) distinguished three classes of sizes as "primary, secondary and tertiary petioles". All the rachides, ranging from 2 to $4.5 \mathrm{~mm}$ in diameter, exhibit a circular transverse section (Plate XVII, 9-10) and similar anatomical features of the epidermis, sclerenchymatous outer cortex, ground tissue and vascular tissues. The characteristic xylem strand is bar-shaped, tangentially elongated (up to $0.9 \times 0.2 \mathrm{~mm}$ in the largest rachides) with two adaxial protoxylem strands (Plate XVII, 11-12).

Corsin (1937) emphasized the strong similarity with the petiole strand of Grammatopteris rigollotii as an argument to attribute these rachides to the genus Grammatopteris. Furthermore, he documented similarities in the lateral emission of small circular "secondary petiole traces", which are here interpreted as pinna traces. Pinnae alternately borne on large rachides (PIN, Plate XVII, 9) are very small organs

\section{Plate XVII.}

1-4: $\quad$ Grammatopteris rigollotii, holotype specimen. Corsin's (1937, Plate I, 1) slide, Univ. Lille.

1. Transverse section of the stem, with protostele $(\mathrm{S})$, surrounded by the mantle of petioles $(\mathrm{P})$ and roots $(\mathrm{R})$. One root $(\mathrm{r})$ shows horizontal course. Scale bar $=10 \mathrm{~mm}$. Detail of the stem showing the solid protostele with the last departing leaf traces arrowed, one root trace (RT) and difference in color between inner cortex (IC) and middle cortex (MC). Scale bar $=1 \mathrm{~mm}$.

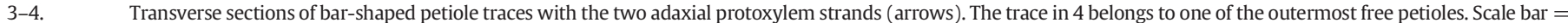
$1 \mathrm{~mm}$.

5-8. Grammatopteris freitasii, paratype specimens. K 4893 (6-7) and K 4894 (5, 8) Naturkunde Museum, Chemnitz

5. Partial transverse section of the small trunk, with protostele $(\mathrm{S})$, surrounded by the mantle of petioles $(\mathrm{P})$ and roots $(\mathrm{R})$. Scale bar $=10 \mathrm{~mm}$

6. Detail of the stem showing the solid protostele with the last departing leaf traces arrowed. Scale bar $=1 \mathrm{~mm}$.

7. Detail of the protostele with incipient leaf trace xylem (LT), its two lateral protoxylem strands ( $\mathrm{px})$, and one departing root trace (RT). Scale bar $=1 \mathrm{~mm}$

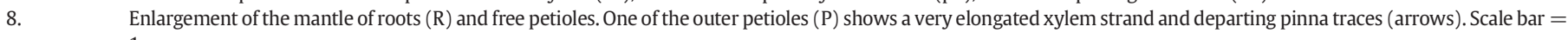
$1 \mathrm{~mm}$.

9-12. $\quad$ Grammatopteris bertrandii, holotype specimen. UL 2421 T3 (10, 12), T4 (9), T5 (11) Univ. Lille.

9. Transverse section of a rachis, showing a circular contour, with attached pinna (PIN). Scale bar $=1 \mathrm{~mm}$.

10. Transverse section of a smaller rachis with attached pinna (PIN) showing vascular branching. Scale bar $=1 \mathrm{~mm}$.

11. Detail of the bar-shaped xylem strand of a relatively small rachis with lateral protoxylem (arrows). Scale bar $=0.5 \mathrm{~mm}$.

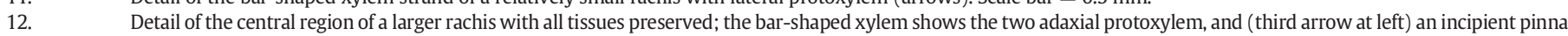
trace. Scale bar $=0.5 \mathrm{~mm}$. 
( $0.5 \mathrm{~mm}$ in diameter proximally and up to $2 \mathrm{~mm}$ long) which may be described as "aphleboid". Pinnae are also borne on smaller rachides (PIN, Plate XVII, 10). They show evidence of vascular branching and have been interpreted by Corsin as "tertiary petioles" sectioned longitudinally. In the absence of stem bearing these isolated rachides, it can be speculated that they belong to median region of fronds and that large rachides (Plate XVII, 9) are proximal to the smaller "secondary petioles" (Plate XVII, 10) instead of bearing them.
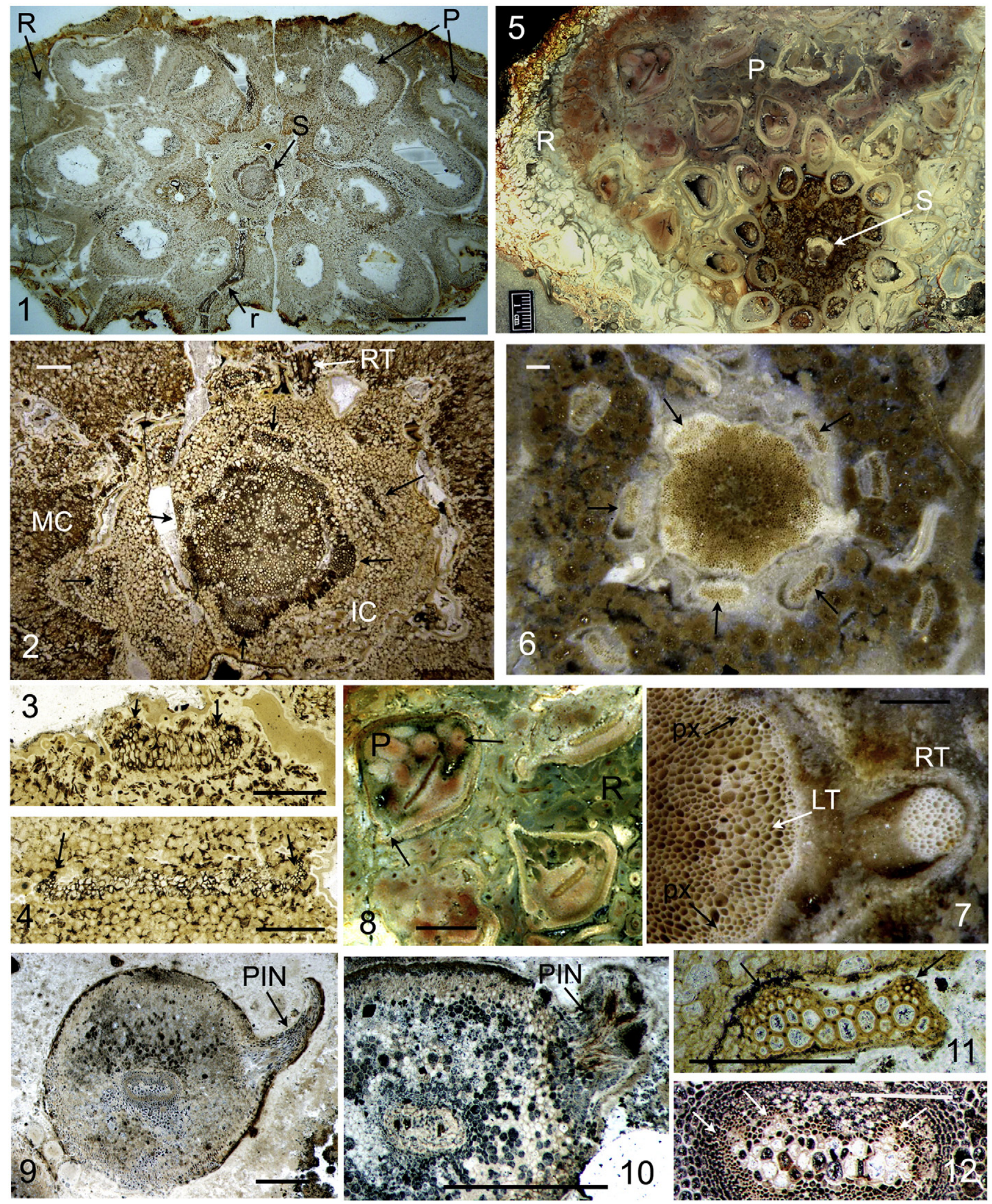


\subsection{Comparison}

Among the three species based on fragments of stems, Grammatopteris freitasii is known in much more detail than Grammatopteris gillotii and Grammatopteris baldaufii, of which proximal regions of trunks have not yet been found. In stelar organization and leaf-trace departure G. freitasii is very similar to G. gillotii (compare Plate XVII, 2 and 6) while G. freitasii and G. baldaufii show similarities in cortical features and origin of root traces abaxially from leaf traces. In all species the diameter of the central stem is within the range (30 to $60 \mathrm{~mm}$ ) observed in G. freitasii; in contrast, the diameter of protostele may exceed $9 \mathrm{~mm}$ in the median to upper region of the trunk of the last species, that is twice larger than in the other two species. If the basal region of free petiole is known in all three species, information on pinna trace emission and on the basal region of pinnae is only known in G. freitasii.

The generic attribution of isolated rachides of Grammatopteris bertrandii was based on strong similarities in xylem strand anatomy and pinna emission with the other species. However, G. bertrandii is rather enigmatic: firstly in the absence of information on its stem and secondly, in its considerably older age than the other (Permian) species. Despite extensive collecting at the Esnost locality, additional material of this taxon has never been discovered. Nevertheless, its very simple xylem strand with two distant adaxial protoxylem strands is most similar to the foliar xylem of some of the anachoropterids with small antennae (compare Plate XVII, 11 with Plate VIII, 5). This is suggestive of the idea that $G$. bertrandii is presently the oldest known representative of the anachoropterid ferns.

\subsection{Ecology and habit of Grammatopteris}

All the Grammatopteris species are known from non-coal swamp environments; they are associated with clastic (Grammatopteris freitasii), if not volcaniclastic substrates (Grammatopteris baldaufii) or eventually both (Grammatopteris gillotii and Grammatopteris bertrandii). The large size of these ferns is comparable to that of some anachoropterids and Tubicaulis which are also related to clastic substrates and it has been suggested (cf. Section 4.4) that this acquisition of a robust stature may reflect higher nutrient environments than those of coal swamps. With the exception of G. freitasii, all species are based on one or two specimens. In contrast the numerous specimens collected of $G$. freitasii suggest a very successful adaptation of this tree fern.

Grammatopteris rigollotii and Grammatopteris baldaufii had unbranched erect stems with a relatively thick mantle (about $8 \mathrm{~cm}$ in diameter) of large petiole bases and roots, characteristic of an upright habit. They were interpreted as small tree ferns with relatively large leaves of which the distal part is unknown. Grammatopteris freitasii has been reconstructed as a tree fern with a trunk up to $40 \mathrm{~cm}$ in diameter and probably several meters in height. The trunk was mechanically supported by a mantle of adventitious aerial roots whose thickness increased toward the base. As a result, this species represented one of the largest Paleozoic tree fern not belonging to the psaronialean group. As suggested by Rössler and Galtier (2002), a buttressed base probably also existed in more proximal trunk regions of the other two species, G. rigollotii and G. baldaufii. The habit of Grammatopteris bertrandii is unknown because of the lack of cauline parts. The circular section of the rachides is reminiscent of those of zygopterid phyllophores known in the contemporaneous Diplolabis and Metaclepsydropsis where the erect foliar rachides were borne on a creeping rhizome. If a similar habit existed in G. bertrandii, we may speculate that the stem would certainly not conform to the generic diagnosis of Grammatopteris.

\subsection{Relationships of Grammatopteris}

Some Tubicaulis and Grammatopteris have a nearly identical cauline anatomy, particularly concerning their solid protostele and the departing bar-shaped leaf trace with two lateral protoxylem strands. This is evident if one compares sections of Tubicaulis solenites and Tubicaulis sutcliffii (Plate XII, 1, 2, 4, 5) with those of Grammatopteris rigollotii and Grammatopteris freitasii (Plate XVII, 1, 2, 5, 6). On the basis of such similarities Corsin (1937) attributed both genera to the order Inversicatenales. However, the taxa differ in their petiole traces which become C-shaped, with antennae extending abaxially beyond the protoxylem strands, in Tubicaulis (Plate XII, 3, 7) while they remain bar-shaped, and therefore not typically inversicatenaleans, in Grammatopteris (Plate XVII, 3, 4, 8). This genus was either classified within the Anachoropteridaceae (Andrews and Boureau, 1970; see also Taylor et al., 2009) or, considering the basic filicalean organization in the geometry of its foliar xylem, attributed to an incertae sedis group of Palaeozoic ferns, as a possible link to the osmundalean ferns (Phillips, 1974; Galtier and Phillips, 1996; Rössler and Galtier, 2002). Several authors (e.g. Sahni, 1932a) mentioned Grammatopteris as a possible progenitor of the Osmundales. Miller (1971) emphasized their stelar and cortical similarities but he considered that the double protoxylem strand and the lack of adaxial curvature of the leaf trace of Grammatopteris depart from the conditions expected of a precursor to the Osmundales. Rastropteris (Galtier et al., 2001), from the Early Permian of China, has been interpreted as related to the contemporaneous Grammatopteris but it is closer to the Osmundaceae, with regard to its leaf trace with, initially, a single protoxylem strand and its adaxially curved petiole xylem. The protostelic Thamnopteroideae from the Permian flora of Angara are considered as the most primitive members of the Osmundales; however, they are contemporaneous with advanced siphonostelic forms (Palaeosmunda, Guairea, Schuichengella, Zhongmingella) known in Cathaysia and Gondwana from both coalswamps and non-coal-swamp environments (Gould, 1970; Miller, 1971; Herbst, 1981; Li, 1983, 1993; Wang et al., 2013). This suggests that the Osmundales probably evolved during the Late CarboniferousEarly Permian from a yet poorly known group of protostelic ferns. Both Grammatopteris and Rastropteris probably belong to this group but none of them can be considered as the actual progenitor. Of interest, a recent phylogenetic analysis of Osmundales (Wang et al., 2013), with Rastropteris as an outgroup, shows Grammatopteris as a member of a polytomy with the Thamnopteroideae.

\section{Discussion}

\subsection{Stele and leaf trace origin}

Most anachoropterids are characterized by a primitive cauline anatomy with a solid cylindrical protostele; more rarely there is a parenchymatized protostele (some Tubicaulis). Psalixochlaena stands apart with centrach permanent protoxylem strands and an initially monarch leaf trace. Other anachoropterids have a slightly mesarch to (?) exarch protostele, and exceptionally (Anachoropteris sp., Apotropteris) a siphonostele with minute pith which may be considered as more advanced. In both Tubicaulis and Grammatopteris the leaf trace originates as an oval bar-shaped xylem with two lateral protoxylem strands, a feature reminiscent of the initial leaf trace in zygopterids (Phillips and Galtier, 2005) which may be considered as primitive.

It is noteworthy that in anachoropterids there is no evidence of secondary growth patterns, neither in xylem nor in cortex, as do some members of zygopterid and ankyropterid ferns (Phillips and Galtier, 2005, 2011).

\subsection{Leaf evolution}

In contrast to the situation in zygopterids and ankyropterids (Phillips and Galtier, 2005, 2011), the anachoropterids possessed perfectly dorsiventral megaphylls similar to those of modern ferns. Their distinctive characters are the reverse orientation (inversicatenalean anatomy) of the C-shaped petiole xylem with abaxial concavity and 
the occurrence of two main adaxial protoxylem strands which are involved in pinna traces emission.

Evolutionary changes concern petiole/rachis xylem configuration with regard to the degree of development of abaxial arms. As illustrated in Fig. 1, there are several trends towards: very short arms, simply recurved arms and much inrolled arms. They have been used as a basis of distinction of several "groups" of Anachoropteris which appear to have radiated very early in basal Pennsylvanian. In Tubicaulis, the ontogenetic change of the petiole trace from bar-shaped to C-shaped has been well documented while it does not occur in Grammatopteris. These examples of changes may be interpreted as mosaic evolution of the foliar organ anatomy.

Information on the distal regions of the frond is known in a few examples only: Sermaya, Doneggia, Kaplanopteris, Psalixochlaena and a new fertile American Anachoropteris. In most cases the pinnules are very small, dissected and sphenopteroid. This is in accordance with the slow evolutionary process of basipetal webbing of the fern leaf as described previously in zygopterids and ankyropterids (see also Galtier, 2010). Some Anachoropteris leaves possess very recurved basal secondary pinnae, called aphlebiae by Corsin (1937); we suggest that they are not protective, as the aphlebiae of zygopterids and ankyropterids, but rather seem to represent adaptations to climbing.

\subsection{Sporangial organization}

Where known, all the sporangia are grouped in sori and have a lateral annulus but they differ in their arrangement and correspond to slightly distinct morphological types. Sori are generally superficial, with radially arranged small sporangia in Sermaya but sori are larger and consisting of broader sporangia in Doneggia (Sermayaceae). In Kaplanopteris the sori are indusiate and pedicellate, bearing a large number of very small sporangia with a long pedicel. Psalixochlaena shows marginal sori of a few sporangia. These differences illustrate different evolutionary trends and support the distinction of the families Sermayacae, Kaplanopteridaceae and Psalixochlaenaceae, and one additional family should be justified for the new fertile American Anachoropteris showing adaxial, superficial, large branched sori bearing broader sporangia. The late Pennsylvanian was certainly the time of radiation of these anachoropterid ferns. Unfortunately information on the fertile parts of most species of Anachoropteris and also of Tubicaulis, Grammatopteris and Apotropteris is still missing.

\subsection{Roots}

All roots have a diarch xylem strand. They developed endogenously from cauline xylem of rhizomes (Psalixochlaena) or of epiphyllous shoots and they have both absorptive and anchoring functions. However, in taxa with erect stems (Tubicaulis with solid protosteles and Grammatopteris) the root insertion is associated with the leaf trace. In this case, as in erect zygopterids and ankyropterids and in present tree ferns, the roots constitute a buttress/mantle with a major supporting function.

\subsection{Ecology, habit and fern responses to severe disturbances, including rapid burial}

The rhizomatous Psalixochlaena and epiphyllous shoots borne on Anachoropteris rachides, known from coal balls, certainly grew initially along substrate surface in coal swamp habitats. However, other occurrences of epiphyllous shoots are also known from non-coal-swamp environments. There is no obvious adaptation to semi aquatic habitat; the only possible exception is the "lacunous" cortex of petioles borne on Tubicaulis type of stems with parenchymatized protostele (from coal balls); surprisingly, a similar cortex exists in Anachoropteris rachides known from non coal-swamp environments.
In our studies of anatomically preserved Filicales in the late Paleozoic, it has not escaped our notice that so many buried assemblages of the small ferns (anachoropterid, botryopterid) have some foliar members with evidence of adventitious shoot production and potential for vegetative propagation. Most of the adventitious shoots exhibit limited development and many have partially preserved bud-like structures with delicate incipient crosiers and protective ramentum. Some shoots are more fully developed and a few give rise to substantial plants as in Botryopteris forensis (Galtier and Phillips, 1977; Rothwell, 1991). These foliar borne shoots are clearly a means of vegetative propagation. It is noteworthy that most of these small ferns only rarely exhibit branching of the main stem. The most notable exceptions are Psalixochlaena (Holmes, 1977) and two closely related species, Botryopteris dichotoma and Botryopteris mucilaginosa (Kraentzel, 1934; Holmes and Galtier, 1983).

Botryopteridaceae: With the many observations of foliar borne shoots on foliar members since their discovery by Long (1943) for Botryopteris hirsuta (see also Delevoryas and Morgan, 1954; Corsin, 1956; Holden, 1962; Galtier, 1969, 1970; Phillips, 1970, 1974; Holmes and Galtier, 1976; Holmes, 1984, 1989; Rothwell, 1991; Rothwell and Good, 2000; Rössler and Galtier, 2003; Tomescu et al., 2006, 2008; Galtier, 2010), it is clear that the responses of the plants represent a means of vegetative propagation. These responses no doubt served them well when there were blow downs, severe disturbances or sudden burial. All of these plants were relatively small, and whether they were rhizomatous, erect or climbing, they were easily felled and covered over by the abundant litter and of associated disturbances of the coal swamp. In our opinion, the frequent encounters with so many variously developed adventitious shoots on foliar members represent plant responses to the disturbances and/or burial. Perhaps the potential preservation of such delicate young apical tissues was enhanced as a result of their trauma and developmental response upon burial.

Tedeleaceae: In addition to the small filicalean ferns, specimens of Ankyropteris brongniartii occasionally show extended proliferation of the axillary shoot and exceptional preservation of even the procambial strands in the developing shoot (Phillips and Galtier, 2011, Plate V, 1-5). Such preservation may be attributed partially to the burial of living plants which still sustained development in their axillary shoots.

Zygopteris-Zygopteridales: Responses to burial have been noted in Zygopteris whereby the axial rhizome is covered by litter while still alive. One clear response was to undergo repeated dichotomies, usually in the same plane along a short distance, resulting in progressively smaller rhizomes up to four prior to death. Less clear, as a general response to severe disturbances and/or burial, are the production of dormant bud-like structures in Zygopteris. The dormant structure consisted of either or both incipient crosier cloaked in aphlebiae and true buds of a shoot with aphlebial primordial to clasping protective aphlebiae providing full cover. The preservational state of these structures range from dried (?discarded) to delicately preserved apical structures. The dormant crosiers and the laterally borne "shoots" on the rhizome, which are buried dormant buds, obviously constitute a much more complex kind of adaptation involving dormancy, first discovered by Dennis (1974). Zygopteris illinoiensis (Middle Pennsylvanian) and Zygopteris berryvillensis (Upper Pennsylvanian) (Phillips and Galtier, 2005) exhibited dormant lateral shoots (bulbil-like) which gave the plant means of surviving prolonged environmental changes of numerous kinds: extreme xeric conditions to burial, flooding or even ground fire associated with drought conditions. Such environmental conditions associated with drought may have been the one and main selective factor developed outside of coal swamps, but providing a response to other severe disturbances.

\section{Conclusions}

A century ago Seward (1910) used "coenopterid" for the anatomically preserved late Paleozoic ferns with many characters of extant 
filicalean families but in different combinations from all. In the quest for ancestral origin of the Filicales in the late Paleozoic, new families have been established (Anachoropteridaceae, Botryopteridaceae, Kaplanopteridaceae, Psalixochlaenaceae, Sermayaceae, Skaaripteridaceae, Tedeleaceae, see Taylor et al., 2009) and insight has been provided on the origins of siphonosteles, axillary branching, indusial, gradate soral maturation, sporangial development and dehiscence as well as some whole plant reconstructions (Ankyropteris brongniartii, Botryopteris antiqua and Botryopteris forensis, Kaplanopteris, Psalixochlaena).

Vegetative propagation from shoots borne on foliar members is typical in both anachoropterid and botryopterid ferns. Laminate pinnules of Sphenopteris and Pecopteris-type are common in these ferns, but knowledge of such for most species is still lacking.

The inverted C-shaped orientation of the foliar xylem (inversicatenalean) of anachoropterid ferns stands out in contrast to other ferns. In this peculiar context, it is puzzling that the new anachoropterid fern with such a multibranched receptacle has the gradate sori on the adaxial surface of the pinnules. If the frond were turned upside down, the xylem strand would be catenalean and the sori would be abaxially superficial as is common in filicaleans. This raises the basic question as to what other anachoropterids may have adaxial sori and what this divergence may have led to evolutionarily.

Finally, one must emphasize the lack of well supported evidence of compressions belonging to the anachoropterid ferns. It has been suggested that Oligocarpia, previously assigned to the Gleicheniaceae, may represent fertile parts of the Sermayaceae. However, in the absence of evidence of anatomy of anachoropterid-type in Oligocarpia, it is premature to include this taxon within the last family only on the basis of similarities in sporangial and spore morphology.

\section{Acknowledgments}

This paper is dedicated to the memory of John Holmes for his outstanding contribution to our knowledge of this group of ferns. This paper is an opportunity to present some still unpublished results of his work.

We are particularly indebted to M. Fairon-Demaret and P. Gerrienne (Liège) for the loan of coal ball material from Bouxharmont used in this study, J.P. Laveine for the loan of sections of Grammatopteris from the Collections of the Université de Lille, and also H. Kerp (Münster) and R. Rössler (Chemnitz) who generously provided us with information and pictures of specimens used in this study. M. Millay kindly sent to John Holmes the Tubicaulis stem specimen illustrated on Plate VII, 7. We thank also J. Dejax (Paris), E.M. Friis (Stockholm), J. Kvacek (Prague), and D. Chabard (Autun) for access to collections. Alice Prickett (School of Life Sciences, Univ. of Illinois) rendered the reconstructions of American anachoropterids and Elisabeth Garrone, Montpellier, the reconstructions of Psalixochlaena and European anachoropterids. H. Kerp and two anonymous reviewers are warmly acknowledged for their constructive criticism.

\section{References}

Abbott, M.L., 1954. Revision of the Paleozoic fern genus Oligocarpia. Palaeontographica B 96, 38-65.

Andrews, H.N., Boureau, E., 1970. Classe des Coenopteridopsida. In: Boureau, E. (Ed.), Traité de Paléobotanique, 4 (1). Filicophyta, Masson, Paris, pp. 33-117.

Bancroft, H., 1915. A contribution to our knowledge of Rachiopteris cylindrica Will. Ann. Bot. 29, 532-565

Beck, R., 1920. Ueber Protothamnopteris Baldaufi nov. sp. Einene neuen verkieselten farn aus dem Chemnitzer Rotliegenden. Abh. Sächs. Akad. Wiss. Math. Phys. Kl. 36, 513-522.

Beckary, S., 1988. Etude anatomique des végétaux des coal balls carbonifères du site de Truebano, province de Leon, Espagne. Unpublished Thesis, Univ. Lille.

Bertrand, P., 1909. Etudes sur la fronde des Zygoptéridées. Danel, Lille.

Bertrand, C.-E., Bertrand, P., 1911. Le Tubicaulis berthieri (sp. nov.). Bull. Soc. Hist. Nat Autun 24, 1-50.

Bierhorst, D.W., 1974. Variable expression of the appendicular status of the megahyll in extant ferns with particular reference to the Hymenophyllaceae. Ann. Mo. Bot. Gard. 61, 408-426.
Brousmiche, C., 1983. Les fougères sphénoptéridiennes du bassin houiller Sarro-Lorrain (Systématique-Stratigraphie). Soc. Géol. Nord Publ. 10, 1-480.

Corda, A.J., 1845. Flora Protogaea. Beiträge zur Flora der Vorwelt. Calvary and Co., Berlin.

Corsin, P., 1937. Contribution à l'étude des Fougères Anciennes du Groupe des Inversicaténales. G. Sautai, Lille.

Corsin, P., 1956. Sur la morphologie de Botryopteris ramosa Williamson. Ann. Sci. Nat Bot. 17, 304-312.

Cotta, B. von, 1832. Die Dendrolithenin Beziehung auf ihren inneren Bau. Arnoldische Buchhandlung, Dresden (89 pp.).

Dasanayake, M.D., 1960. Aspects of morphogenesis in a dorsiventral fern, Pteridium aquilinum (L.) Kuhn. Ann. Bot. 24, 317-328.

Delevoryas, T., Morgan, J., 1952. Tubicaulis multiscalariformis: a new American coenopterid. Am. J. Bot. 39, 160-166.

Delevoryas, T., Morgan, J., 1954. A further investigation of the morphology of Anachoropteris clavata. Am. J. Bot. 41, 192-198.

Dennis, R.L., 1974. Studies of Paleozoic ferns: Zygopteris from theMiddle and Upper Pennsylvanian of the United States. Palaeontographica B 148, 95-136.

DiMichele, W.A., Phillips, T.L., 2002. The ecology of Paleozoic ferns. Rev. Palaeobot. Palynol. 119, 143-159.

Eggert, D.A., 1959. Studies of Paleozoic ferns: Tubicaulis stewartii sp. nov; and evolutionary trends in the genus. Am. J. Bot. 46, 594-602.

Eggert, D.A., Delevoryas, T., 1967. Studies of Paleozoic ferns: Sermaya, gen. nov. and its bearing on filicalean evolution in the Paleozoic. Palaeontographica B 120, 169-180.

Felix, J., 1886. Untersuchung über den inneren Bau westfälischer Carbonplflanzen. Abh. Geol. Specialkarte Preuss. Thüring Staaten 7, 153-225.

Galtier, J., 1969. Observations sur les structures foliaires et caulinaires de Botryopteris antiqua Kidston. C. R. Acad. Sci. Paris 268, 3025-3028.

Galtier, J., 1970. Recherches sur les végétaux à structure conservée du Carbonifère inférieur français. Paléobiol. Cont. 1 (4), 1-221.

Galtier, J., 1971. La fructification de Botryopteris forensis Renault, Coenopteridales du Stéphanien français. Précisions sur les sporanges et les spores. Nat. Monspel. Ser. Bot. 22, 145-155.

Galtier, J., 1997. Coal-ball floras of the Namurian-Westphalian of Europe. Rev. Palaeobot Palynol. 95, 51-72.

Galtier, J., 2008. A new look at the permineralized flora of Grand-croix (Late Pennsylvanian, Saint-Etienne basin, France). Rev. Palaeobot. Palynol. 152, 129-140.

Galtier, J., 2010. The origins and early evolution of the megaphyllous leaf. Int. J. Plant Sci. $171,641-661$.

Galtier, J., Holmes, J., 1982. New observations on the branching of Carboniferous ferns and pteridosperms. Ann. Bot. 49, 737-746.

Galtier, J., Holmes, J., 1984. Sur les fougères Anachoropteris et Tubicaulis du Stéphanien français. Description de Tubicaulis grandeuryi nov. sp. Geobios 17, 757-770.

Galtier, J., Phillips, T.L., 1977. Morphology and evolution of Botryopteris, a Carboniferous age fern. Part 2. Observations on Stephanian species from Grand-Croix, France. Palaeontographica B 164, 1-3.

Galtier, J., Phillips, T.L., 1996. Structure and evolutionary significance of Palaeozoic ferns In: Camus, J.M., Gibby, M., Johns, R.J. (Eds.), Pteridology in Perspective. Royal Botanic Gardens, Kew, pp. 417-433.

Galtier, J., Phillips, T.L., 1999. The acetate peel technique. In: Jones, T.P., Rowe, N.P. (Eds.), Fossil Plants and Spores: Modern Techniques. The Geological Society, London, pp. 66-71.

Galtier, J., Scott, A.C., 1985. Diversification of early ferns. Proc. R. Soc. Edinb. B 86, 289-301.

Galtier, J., Wang, S.-J., Li, C.-S., Hilton, J., 2001. A new genus of filicalean fern from the Lower Permian of China. Bot. J. Linn. Soc. 137, 429-442.

Galtier, J., Ronchi, A., Broutin, J., 2011. Early Permian silicified floras from the Perdasdefogu Basin (S.E. Sardinia): comparison and bio-chronostratigraphic correlation with the floras of the Autun basin (Massif Central, France). Geodiversitas 33, 43-69.

Gould, R.E., 1970. Palaeosmunda, a new genus of siphonostelic osmundaceous trunks from the Upper Permian of Queensland. Palaeontology 13, 10-28.

Graham, R., 1935. Pennsylvanian flora of Illinois as revealed in coal balls. II. Bot. Gaz. 97, $156-168$.

Hall, J.W., 1961. Anachoropteris involuta and its attachment to a Tubicaulis type of stem from the Pennsylvanian of Iowa. Am. J. Bot. 48, 731-7327.

Herbst, R., 1981. Guairea milleri nov. gen. et sp. y Guaireaceae, nueva familia de las Osmundales (sensu lato) del Permico superior de Paraguay. Ameghiniana 18, 35-50.

Hilton, J., Wang, S.-J., Galtier, J., Glaspool, I., Stevens, L., 2004. An Upper Permian permineralized plant assemblage in volcaniclastic tuff from the Xuanwei Formation, Guizhou Province, southern China, and its palaeofloristic significance. Geol. Mag. 141, 661-674.

Hirmer, M., 1927. Handbuch der Paläobotanik: Band I-Thallophyta, Bryophyta, Pteridophyta. R. Oldenbourg, München.

Holden, H.S., 1960. The morphology and relationships of Rachiopteris cylindrica. Bull. Br. Mus. Nat. Hist. Geol. 4, 53-69.

Holden, H.S., 1962. The morphology of Botryopteris antiqua. Bull. Br. Mus. Nat. Hist. Geol 5, 361-380.

Holden, H.S., Croft, W.N., 1962. The morphology of Tubicaulis africanus sp. nov. a fossil fern from Tanganyika. Bull. Br. Mus. Nat. Hist. Geol. 7, 199-211.

Holmes, J.C., 1977. The Carboniferous fern Psalixochlaena cylindrica as found in Westphalian A coal balls from England. I. Structure and development of the cauline system. Palaeontographica B 164, 33-75.

Holmes, J.C., 1979. Foliar borne stems in Anachoropteris gillotii from the lower Westphalian of Belgium. Can. J. Bot. 57, 1518-1527.

Holmes, J.C., 1981a. The Carboniferous fern Psalixochlaena cylindrica as found in Westphalian A coal balls from England. II. The frond and fertile parts. Palaeontographica B 176, $147-173$.

Holmes, J.C., 1981b. Structure et évolution des Fougères Coenopteridales (Anachoropteridaceae et Botryopteridaceae) du Carbonifère supérieur d'Europe. 
Contribution à l'histoire de la ramification des végétaux supérieurs. (Thèse) Université S. T. L. Montpellier.

Holmes, J.C., 1984. Morphology and evolution of Botryopteris, a Carboniferous age fern. IV. Branching patterns of the European species $B$. hirsuta and B. ramosa. Description of $B$. scottii n. sp. Palaeontographica B 191, 1-28.

Holmes, J.C., 1989. Anomalous branching patterns in some fossil Filicales: implications in the evolution of the megaphyll and the lateral branch, habit and growth pattern. Plant Syst. Evol. 165, 137-158.

Holmes, J.C., Fairon-Demaret, M., 1984. A new look at the flora of the Bouxharmont coal balls from Belgium. Ann. Soc Géol. Belg. 107, 73-87.

Holmes, J., Galtier, J., 1976. Twin shoots borne on a Botryopteris frond from the British Upper Carboniferous. Rev. Palaeobot. Palynol. 22, 207-224.

Holmes, J., Galtier, J., 1983. Morphology and evolution of Botryopteris, a Carboniferous age fern. Part III. Botryopteris dichotoma, a new Westphalian species from Belgium with observations on other species. Palaeontographica B 186, 1-17.

Hoskins, J.H., 1930. Contributions to the coal measure flora of Illinois. Amer. Midl. Nat. 12, 154-163.

Hueber, F.M., Galtier, J., 2002. Symplocopteris wyattii n. gen. et n. sp.: a zygopterid fern with a false trunk from the Tournaisian (Lower Carboniferous) of Queensland, Australia. Rev. Palaeobot. Palynol. 119, 241-273.

Iwatzuki, K., 1990. Hymenophyllaceae, in: Kubitzki, K. (Ed.), The Families and Genera of Vascular Plants. I. Pteridophytes and Gymnosperms (Kramer, K.U., Green, P.S. vol. Editors), Springer Verlag Berlin, pp.157-163.

Kidston, R., 1923. Fossil plants of the Carboniferous rocks of Great Britain. Geol. Surv. Great Brit. Palaeont. 2, 275-376.

Koopmans, R.G., 1928. Researches on the flora of the coal balls from the "FinefrauNebenbank» horizon in the province of Limburg (The Netherlands). Geol. Bur. Ned. Mijngebied, Heerlen (53 pp.).

Kraentzel, G., 1934. Etude monographique de Botryopteris mucilaginosa sp. nov. Ann. Soc. Geol. Belg. 56, 51-72.

Kubart, B., 1916. Ein Beitrag zur Kenntnis von Anachoropteris pulchra Corda. Akad. Wien Denkschr. 93, 551-584.

Leary, R.L., 1979. One day field trip guidebook, May 27 1979. IX International Congress of Carboniferous Stratigraphy and Geology.

Leclercq, S., 1925. Introduction à l'étude anatomique des végétaux houillers de Belgique: les coal balls de la couche Bouxharmont des Charbonnages de Werister. Mém. Soc. Géol. Belg. Liège 6, 1-79.

Li, Z.M., 1983. Palaeosmunda emended and two new species. Acta Phytotaxon. Sin. 21 $153-160$

Li, Z.M., 1993. The genus Shuichengella gen. nov. and systematic classification of the order Osmundales. Rev. Palaeobot. Palynol. 77, 51-63.

Long, A.G., 1943. On the occurrence of buds on the leaves of Botryopteris hirsuta Will. Ann. Bot. 7, 133-146.

Long A.G. 1976. Psalixochlaena berwickense sp, nov, a Lower Carboniferous fern from Berwickshire. Trans. R. Soc. Edinb. 69, 513-521.

Mamay, S.H., 1952. An epiphytic American species of Tubicaulis Cotta. Ann. Bot. 16 $145-163$.

Millay, M.A., 1970. A Tubicaulis from the British coal measures. Am. J. Bot. 57, 757.

Millay, M.A., Taylor, T.N., 1980. An unusual Botryopterid sporangial aggregation from the middle Pennsylvanian of North America. Am. J. Bot. 67, 758-773.

Miller Jr., C.N., 1971. Evolution of the fern family Osmundaceae based on anatomical studies. Contrib. Mus. Paleontol. Univ. Mich. 23, 105-169.

Morgan, J., Delevoryas, T., 1954. An anatomical study of a new coenopterid petiole. Am. J. Bot. 41, 198-203.

Oplustil, S., Psenicka, J., Libertin, M., Bashforth, A.R., Simunek, Z., Drabkova, J., Daskova, J. 2009. A Middle Pennsylvanian (Bolsovian) peat-forming forest preserved in situ in volcanic ash of the Whetstone Horizon in the Radnice Basin, Czech Republic. Rev. Palaeobot. Palynol. 155, 234-274.

Phillips, T.L., 1970. Morphology and evolution of Botryopteris, a Carboniferous age fern. 1. Observations on some European species. Palaeontographica B 130,137-172.

Phillips, T.L., 1974. Evolution of vegetative morphology in coenopterid ferns. Ann. Mo. Bot. Gard. 61, 427-461.

Phillips, T.L., 1980. Stratigraphic and geographic occurrences of permineralized coalswamp plants-Upper Carboniferous of North America and Europe. In: Dilcher, D.L. Taylor, T.N. (Eds.), Biostratigraphy of Fossil Plants. Hutchinson and Ross, Stroudsburg PA, pp. 25-92.

Phillips, T.L., Andrews, H.N., 1965. A fructification of Anachoropteris from Middle Pennsylvanian of Illinois. Ann. Mo. Bot. Gard. 52, 251-261.

Phillips, T.L., Galtier, J., 2005. Evolutionary and ecological perspectives of Late Paleozoic ferns. Part I. Zygopteridales. Rev. Palaeobot. Palynol. 135, 165-203.

Phillips, T.L., Galtier, J., 2011. Evolutionary and ecological perspectives of Late Paleozoic ferns. Part II. The genus Ankyropteris and the Tedeleaceae. Rev. Palaeobot. Palynol. $164,1-29$.

Phillips, T.L., Peppers, R.A., DiMichele, W.A., 1985. Stratigraphic and interregional changes in Pennsylvanian coal-swamp vegetation: environmental inferences. Int. J. Coal Geol. $5,43-109$.
Psenicka, J., Bek, J., 2001. Oligocarpia lindsaeoides (Ettingshausen) Stur and its spores from the Westphalian of central Bohemia (Czech Republic). Acta Mus. Nat. Prague B Hist. Nat. 57, 57-68

Remy, W., Remy, R., 1977. Die Floren des Erdaltertums. Verlag Glückauf GmbH, Essen.

Renault, B., 1868. Note sur un pétiole de fougère fossilede la partie supérieure du terrain houiller d'Autun. Ann. Sci. Nat. Bot. 9, 282-286.

Renault, B., 1891. Note sur la famille des Botryoptéridées. Bull. Soc. Hist. Nat. Autun 4, $498-501$

Renault, B., 1893-1896. Bassin Houiller et Permien d'Autun et d'Epinac. Etude des gites minéraux de la France 4. Flore fossile 2.: Atlas (1893); Texte (1896). Imprimerie Nationale, Paris.

Rössler, R., 2000. The late Palaeozoic tree fern Psaronius - an ecosystem unto itself. Rev. Palaeobot. Palynol. 108, 55-74.

Rössler, R., 2001. Der Versteinerte Wald von Chemnitz. Museum für Naturkunde Chemnitz (252 pp.).

Rössler, R., Galtier, J., 2002. First Grammatopteris tree ferns from the Southern Hemisphere new insights in the evolution of the Osmundaceae from the Permian of Brazil. Rev. Palaeobot. Palynol. 121, 205-230.

Rössler, R., Galtier, J., 2003. The first evidence of the fern Botryopteris from the Permian of the Southern Hemisphere reflecting growth form diversity. Rev. Palaeobot. Palynol. 127, 99-124.

Rössler, R., Noll, R., 2002. Der permische versteinerteWald von Araguaina/BrasilienGeologie, Taphonomie und Fossilführung. Veröff. Mus. Naturkunde Chemnitz 25, $5-44$.

Rothwell, G.W., 1978. Doneggia complura gen. et sp. nov., a filicalean fern from the Upper Pennsylvanian of Ohio. Can. J. Bot. 24, 3096-3104.

Rothwell, G.W., 1987. Complex Paleozoic Filicales in the evolutionary radiation of ferns. Am. J. Bot. 74, 458-461.

Rothwell, G.W., 1991. Botryopteris forensis (Botryopteridaceae), a trunk epiphyte of the treefern Psaronius. Am. J. Bot. 78, 782-788.

Rothwell, G.W., Good, C.W., 2000. Reconstructing the Pennsylvanian-age filicalean fern Botryopteris tridentata (Felix) Scott. Int. J. Plant Sci. 161, 495-507.

Sahni, B., 1931. On certain fossil epiphytic ferns found on stems of the Palaeozoic tree-fern Psaronius. Proc. 18th Indian Sc. Congress, Nagpur, India, p. 270.

Sahni, B., 1932a. On a Palaeozoic tree-fern, Grammatopteris Baldaufi (beck) Hirmer. A link between the Zygopteridaceae and osmundaceae. Ann. Bot. 46

Sahni, B., 1932b. On the structure of Zygopteris primaria (Cotta) and on the relations between the genera Zygopteris, Etapteris and Botrychioxylon. Philos. Trans. R. Soc. Lond. 222B, 29-45.

Sahni, B., 1935. The roots of Psaronius, intra-cortical or extra-cortical? - a discussion. Curr. Sci. 3, 555-559.

Scott, D.H., 1920. Studies in Fossil Botany, 3rd ed. Adam and Charles Black, London.

Seward, A.C., 1910. Fossil Plants. A Text-book for Students of Botany and Geology, vol. II. University Press, Cambridge.

Stenzel, G., 1889. Die Gattung Tubicaulis Cotta. Mitt. Koenigl. Min. Geol. Praehist. Mus. Dresd. 8, 1-50.

Stewart, W.N., Rothwell, G.W., 1993. Paleobotany and the Evolution of Plants, 2nd ed. Cambridge Univ. Press, New York.

Stopes, M.C., 1906. A new fern from the coal measures: Tubicaulis sutcliffii spec. nov. Mem. Proc. Manch. Lit. Philos. Soc. 50, 1-35.

Taylor, T.N., Taylor, E.L., Krings, M., 2009. Paleobotany: The Biology and Evolution of Fossil Plants, 2nd ed. Academic Press, Amsterdam.

Tomescu, A.M.F., Rothwell, G.W., Trivett, M.L., 2006. Kaplanopteridaceae fam. nov., additional diversity in the initial radiation of filicalean ferns. Int. J. Plant Sci. 167, 615-630.

Tomescu, A.M.F., Rothwell, G.W., Trivett, M.L., 2008. Reiterative growth in the complex adaptive architecture of the Paleozoic (Pennsylvanian) filicalean fern Kaplanopteris clavata. Plant Syst. Evol. 270, 209-216.

Trivett, M.L., Rothwell, G.W., 1988. Modelling the growth architecture of fossil plants: a paleozoic filicalean fern. Evol. Trends Plants 2, 25-29.

Wang, Y., Guignard, G., Barale, G., 1999. Morphological and ultrastructural studies on in situ spores of Oligocarpia (Gleicheniaceae) from the Lower Permian of Xinjiang, China. Int. J. Plant Sci. 160, 1035-1045.

Wang, S.-J., Hilton, J., He, X.-Y., Seyfullah, L.J., Shao, L., 2013. The anatomically preserved stem Zhongmingella gen nov, from the Upper Permian of China: evaluating the early evolution and phylogeny of the Osmundales. J. Syst. Palaeontol.. http://dx.doi. org/10.1080/14772019.2012.726658.

Webster, B.D., Steeves, T.A., 1958. Morphogenesis in Pteridium aquilinum (L.) Kuhn. I. The rhizome. New Phytol. 39, 401-422.

Williamson, W.C., 1878. On the organization of the fossil plants from the coal measures. Part IX. Philos. Trans. R. Soc. Lond. 159, 319-364.

Winston, R.B., Phillips, T.L., 1991. A structurally preserved Lower Pennsylvanian flora from the New Castle coal bed of Alabama. Geol. Surv. Ala. Circ. 157 (21 pp.).

Zhaoqi, Y., Taylor, T.N., 1988. On a new gleicheniaceous fern from the Permian of South China. Rev. Palaeobot. Palynol. 54, 121-134. 